\title{
Weaving a stronger community
}

\author{
by \\ Laurence Massicotte \\ A thesis submitted to \\ the Faculty of \\ Azrieli School of Architecture \\ Master of Architecture
}

Carleton University

Ottawa, Ontario 
We are now in a time when populations are migrating for political, economic and climatic reasons. Cities are more populous and diverse than ever. In an era of technologies and virtual social networks, our societies are disconnected, fragmented and polarized. To solve these large societal issues, we first need to reconnect; to know and care for our fellow citizens and neighbours. A great way to help build or re-build these bonds within a community is through social infrastructures such as community organizations but also all sorts of public facilities such as libraries, schools, cultural and sports facilities, parks and cafés, all places where people congregate.

This thesis proposes the design of an alternative type of social infrastructure: a multifacetted community institution on the site of the abandoned Empress Theatre in Montreal. The design will focus on creating a set of spatial and programmatic relationships that stimulate the imagination and challenge conventional thinking, with the goal of prompting chance encounters that will help weave a stronger community. 


\section{Acknowledgements}

Thank you so much to my adviser, Lucie Fontein, for her guidance, patience and honesty. Thank you for picking me as one of your last thesis students.

Thank you to Jonathan, for the moral support and for cooking ALL the meals near the end.

Thank you to Alice, for being the voice of reason in doubtful moments.

And thank you to my dear architecture friends for the good memories and for sharing this crazy experience together.

Merci 
Abstract I

Aknowledgements II

Table of Content III

List of Figures IV

\section{WHY}

\section{Introduction}

Living Together

\section{WHERE}

The Site

$\begin{array}{lc}\text { N.D.G. } & 3 \\ \text { The Empress Theatre } & 8 \\ \text { Egyptian Symbolism } & 10 \\ \text { History } & 13 \\ \text { Heritage Value } & 15\end{array}$

WHAT

The Project

The Proposition 19

The Physical 21

Precedents 22

\section{HOW}

\section{The Program}

$\begin{array}{ll}\text { The Annex } & 32 \\ \text { The Empress } & 32 \\ \text { Existing Brick Building } & 35 \\ \text { New Brick Building } & 38 \\ \text { The Drawings } & 40\end{array}$

\section{WHEN}

\begin{tabular}{cc}
$\begin{array}{c}\text { Conclusion } \\
\text { The People } \\
\text { Looking Forward }\end{array}$ & 54 \\
& 67 \\
\hline Bibliography & 68
\end{tabular}


Introduction

Fig. I.0 "Palaces for the People." 2

\section{The Site}

Fig. 2.I Map of N.D.G. - Services 4

Fig. 2.2 Close-up Map of N.D.G. - Services 5

Fig. 2.3 Map of N.D.G. - South 6

$\begin{array}{lll}\text { Fig. } 2.4 \text { N.D.G. Census } 2016 & 7\end{array}$

Fig. 2.5 Empress Theatre 9

Fig. 2.6 Empress Theatre - Section 9

Fig. 2.7 Pharaoh Ptolemy 10

Fig. 2.8 Empress Theatre Façade $\quad 10$

Fig. 2.9 Empress Theatre - Arch \& Curtain, RAIC II

Fig. 2.10 Empress Theatre - Mezzanine Floor, RAIC II

Fig. 2.II Empress Theatre - West Wall RAIC 12

Fig. 2.12 Empress Theatre - $1928 \quad 13$

Fig.2.13 Empress Theatre, $1943 \quad 14$

$\begin{array}{ll}\text { Fig.2.14 Cinema V, } 1989 & 14\end{array}$

Fig.2.15 Cinema NDG, 2019

Fig. 2.16 Cinema NDG - $2014 \quad 15$

Fig. 2.17 Cinema NDG - 2014 15

Fig. 2.18 Cinema NDG - 2014 16

Fig. 2.19 Cinema NDG - $2014 \quad 17$ 


\section{The Project}

Fig. 3.I Empress Hand Sketched Elevations 20

Fig.3.2 Stony Island Arts Bank 23

Fig.3.3 St Laurence School, 23

$\begin{array}{ll}\text { Fig.3.4 DAHC } & 23\end{array}$

Fig.3.5 Garfield Park Power House 23

Fig. 3.6 Granby Winter Garden Axonometric 24

Fig. 3.7 Granby Winter Garden 25

Fig. 3.8 Granby Winter Garden 25

Fig. 3.9 Granby Winter Garden 25

Fig. 3.10 Granby Winter Garden 25

Fig. 3.II Sala Equis Theatre 26

Fig. 3.12 Sala Equis Theatre 26

Fig. 3.I3 Sala Equis Theatre 26

Fig. 3.14 Bâtiment $7 \quad 27$

$\begin{array}{ll}\text { Fig. 3.15 Bâtiment } 7 & 28\end{array}$ 


\section{The Program}

Fig. 4.I Site Plan Before $\quad 30$

Fig. 4.2 Site Plan After 31

Fig. 4.3 Axo of Annex $\quad 32$

Fig. 4.4 Axo of The Empress 34

Fig. 4.5 Axo of Existing Brick Building 36

Fig. 4.6 Axo of New Brick Building 38

Fig. 4.7 Axo of Market $\quad 39$

Fig. 4.8 Ground Floor Plan 4I

Fig. 4.9 Second Floor Plan $\quad 42$

Fig. 4.10 Fourth Floor Plan 43

Fig. 4.II Circulation $\quad 44$

Fig. 4.12 East Section Out $\quad 45$

Fig. 4.13 East Section In 45

Fig. 4.14 North Section Out 46

Fig. 4.15 West Section Out $\quad 47$

$\begin{array}{ll}\text { Fig. 4.16 West Section In } & 47\end{array}$

Fig. 4.17 Linger $\quad 48$

$\begin{array}{lll}\text { Fig. } 4.18 \text { 3rd Spaces } & 48\end{array}$

Fig. 4.19 Unexpected $\quad 49$

$\begin{array}{ll}\text { Fig. } 4.20 \text { Unexpected } & 49\end{array}$

$\begin{array}{ll}\text { Fig. 4.2I Flexible } & 50\end{array}$

$\begin{array}{ll}\text { Fig. } 4.22 \text { Flexible } & 50\end{array}$

Fig. 4.23 Juxtaposition 5 I

Fig. 4.24 Juxtaposition 5 I

Fig. 4.25 Inclusive $\quad 52$ 


\section{Conclusion}

Fig. 5.I East Section I.I 54

Fig. 5.2 Abdou $\quad 55$

Fig. 5.3 Greg $\quad 55$

$\begin{array}{ll}\text { Fig. } 5.4 \text { Felix } & 56\end{array}$

Fig. 5.5 East Section 2.1 57

Fig. 5.6 Étienne $\quad 57$

$\begin{array}{ll}\text { Fig. } 5.7 \text { Helen } & 58\end{array}$

$\begin{array}{ll}\text { Fig. } 5.8 \text { Dominic } & 40\end{array}$

Fig. 5.9 North Section 2.1 59

Fig. 5.10 Tony 59

Fig. 5.II Paul $\quad 60$

Fig. 5.12 Leila $\quad 60$

Fig. 5.13 Gabriel 61

Fig. 5.14 Amahd 61

$\begin{array}{ll}\text { Fig. } 5.15 \text { Jeanette } & 62\end{array}$

Fig. 5.16 Barber Shop $\quad 62$

Fig. 5.17 Bike Shop $\quad 62$

Fig. 5.18 West Section 3.1 63

Fig. 5.19 Irene 63

Fig. 5.20 Sylvia $\quad 64$

$\begin{array}{ll}\text { Fig. 5.2I Mai } & 64\end{array}$

$\begin{array}{ll}\text { Fig. } 5.22 \text { Liem } & 65\end{array}$

$\begin{array}{ll}\text { Fig. } 5.23 \text { Catherine } & 65\end{array}$

Fig. 5.24 West Section $3.2 \quad 66$

$\begin{array}{ll}\text { Fig. } 5.25 \text { Marie } & 65\end{array}$ 


\section{Introduction}

\section{Living Together}

Montreal has always been known as a multicultural city. As the point of entry for most immigrants to the province, the different cultural communities of Montreal have significantly contributed to the identity of the city. ${ }^{1}$ For a long time the quarrel between Francophones and Anglophones was the main issue, but nowadays, the pressing question is, how do we make room for new cultures and how do we learn to cohabit in a respectful manner? Although this situation is specific to Montreal, it is not unique to it. In fact, , this question is the 2020 Venice Biennale's theme: "How will we live together?". Hashim Sarkis, the curator of this year's Biennale said: "In the context of widening political divides and growing economic inequalities, we call on architects to imagine spaces in which we can generously live together." II

In his book Palaces for the People, Eric Klinenberg argues that social infrastructures can help fight inequality, isolation and polarization. His research is based in the United States but he mentions that the situation is quite similar in other developed nations when he says that we are facing profound challenges "including climate change, aging population, runaway inequality, and explosive ethnic divisions - that we can address only if we establish stronger bonds with one another, and develop some shared interests too." "II Basically he is saying that if we want to solve larger scale issues we need to first restore social cohesion and community networks within a fractured society. This cohesion can be achieved through repeated human interaction in shared spaces, and joint participation in communal projects. Klinenberg believes, that social infrastructures, which include all sorts of public institutions as well as parks, can strongly help weave our communities back together.

In response to his challenge, my thesis explores if a mixed-use public institution that is designed to strengthen the social network of a multicultural community in a chosen neighbourhood of Montreal; a new kind of institution that works in an alternative way that truly responds to the needs of the local population.

\footnotetext{
I Foucarde. Montreal's Cultural Diversity Heritage (2009)

II "Biennale Architettura 2020: How will we live together?," La Biennale Di Venezia

III Klinenberg. Palaces for the People (20I9).
} 


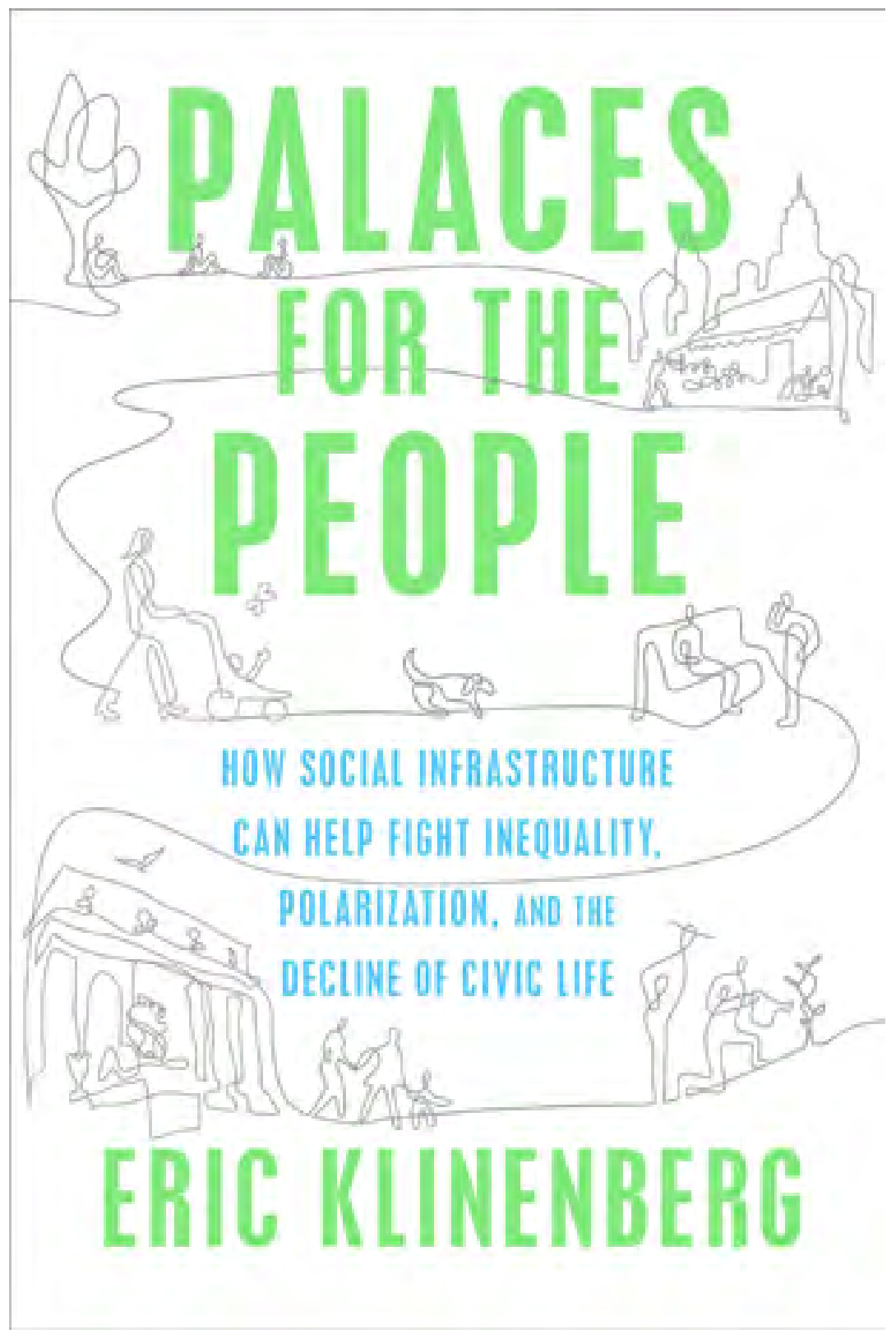

Fig. I. O Palaces for the People 


\section{The Site}

\section{Notre-Dame-de-Grâce}

Notre-Dame-de-Grâce, better known as N.D.G., is located on the west side of Mont Royal. Prior to the 20th century it was mostly agricultural land. During the 1920's, with the arrival of the tramway on Sherbrooke street, the area began to develop in a more urban way. Civic buildings such as a post office, a bank and a cinema started to appear.'

Today, N.D.G is well situated in terms of transportation. It is right next to one of the main highways that run through Montreal, it has two metro stations within the neighbourhood, it is served by many different bus lines and it has a few bike path serving the schools and one going all the way across to the east side of the city.

The neighbourhood is mostly residential and composed of brick buildings, usually less than four stories high. A few shops can be found along Monkland and Sherbrooke streets. N.D.G. also counts many elementary schools and high schools, as well as a Campus for Concordia University, lots of sports facilities and a few libraries. The whole district is populated with many big old trees. The neighbourhood is therefore quite inviting for families. (see figure 2.1)

N.D.G. is known for being somewhat of a bourgeois neighbourhood with its old anglophones families that have been established there for many decades. There is also a wealthy francophone section. However, contrary to popular belief, there is another side to it. Sherbrooke street forms a division between higher income residents to the north and lower to the south. There are also some considerable pockets of poverty along the Canadian Pacific Railway that crosses the area. Furthermore, this southern area of the neighbourhood includes a Jamaican diaspora, which arrived in the 60's and was followed by waves of Italians, Eastern Europeans and Iranians fleeing the revolution. ${ }^{2}$ (see figure 2.2)

This southern section of the neighbourhood suffers from poor access to local shops and consequently to fresh food products. The area of north of Sherbrooke street does not encounter the same challenges. Research by Le Centre d'Écologie Urbaine de Montréal, concluded that the neighbourhood needs better diversity and accessibility to shops as well as a built environment that is inclusive and represents the social mix of the area while still being considerate of the history and architectural heritage of the neighbourhood. ${ }^{3}$ (see figure 2.3)

Finally, N.D.G. park, which is considered by the locals to be the heart of the neighbourhood and a cultural centre for the community is situated on that Sherbrooke Street division line, just west of the Decarie Expressway. Straight across, on the corner of Sherbrooke and Old 


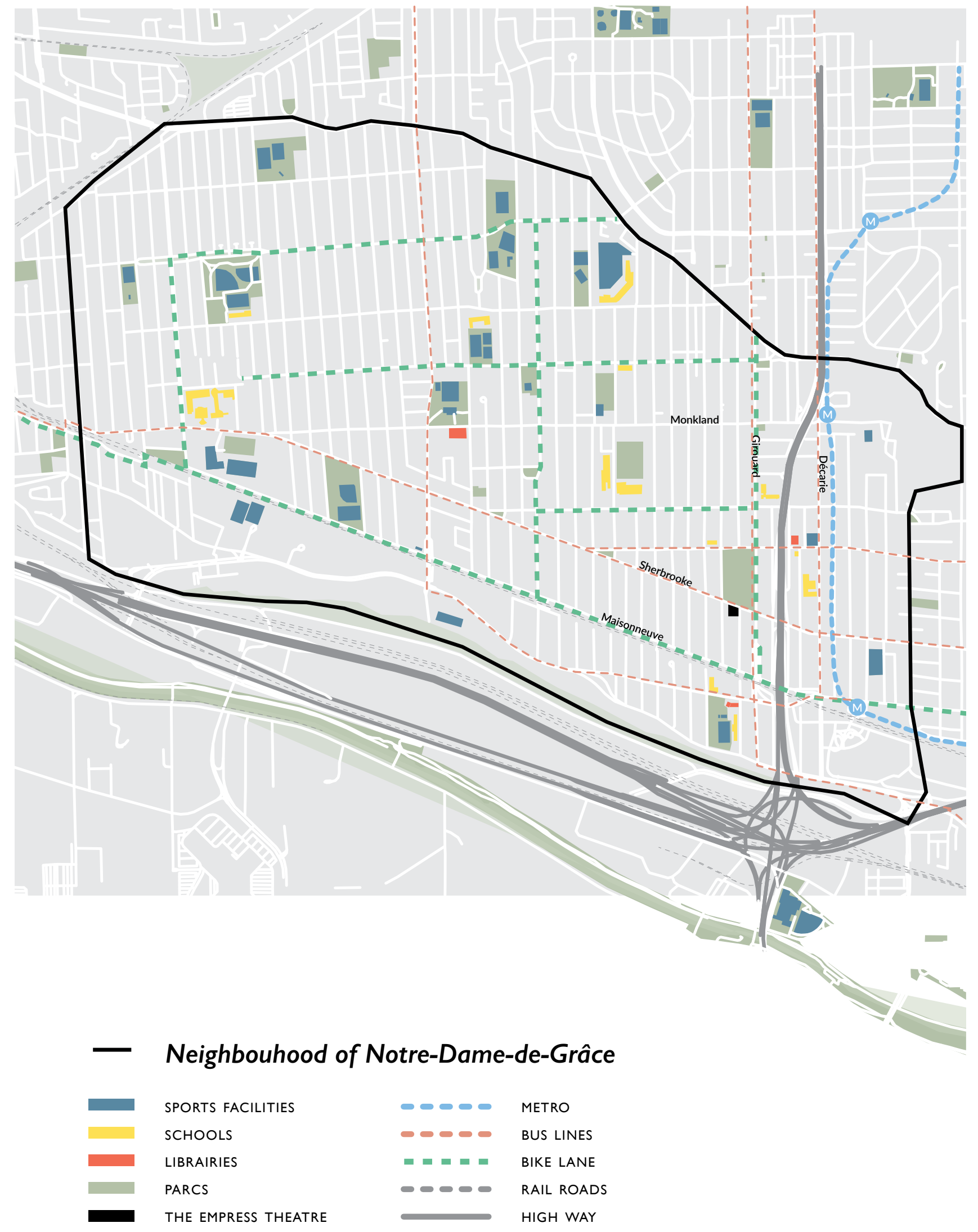

Fig. 2.I Map of N.D.G. - Services 


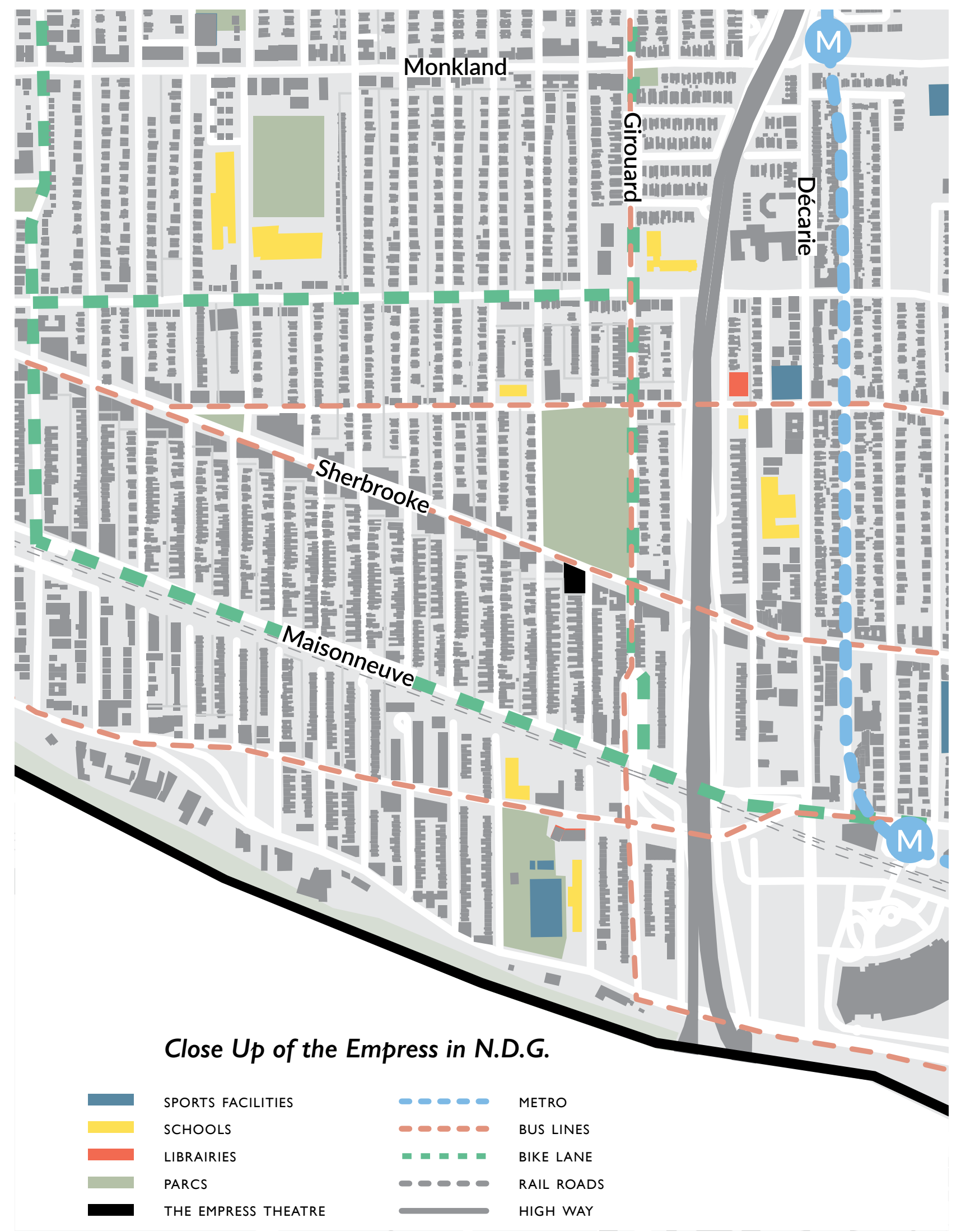

Fig. 2.2 Close-up Map of N.D.G. - Services 


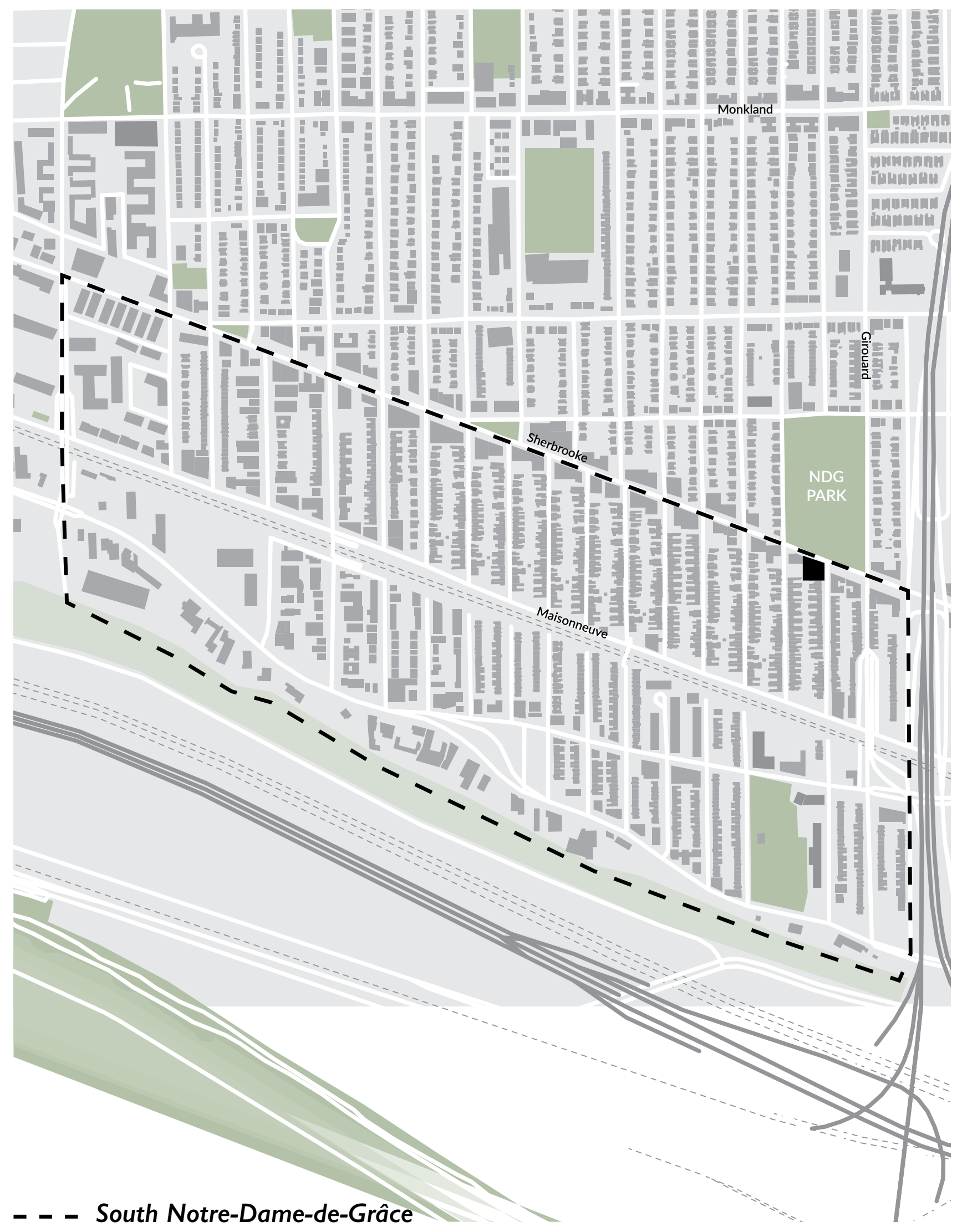

Fig. 2.3 Map of N.D.G. - South 
HOUSEHOLDS SIZES

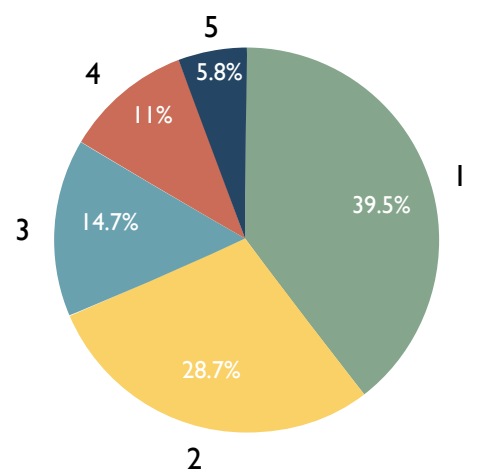

IMMIGRATION STATUS

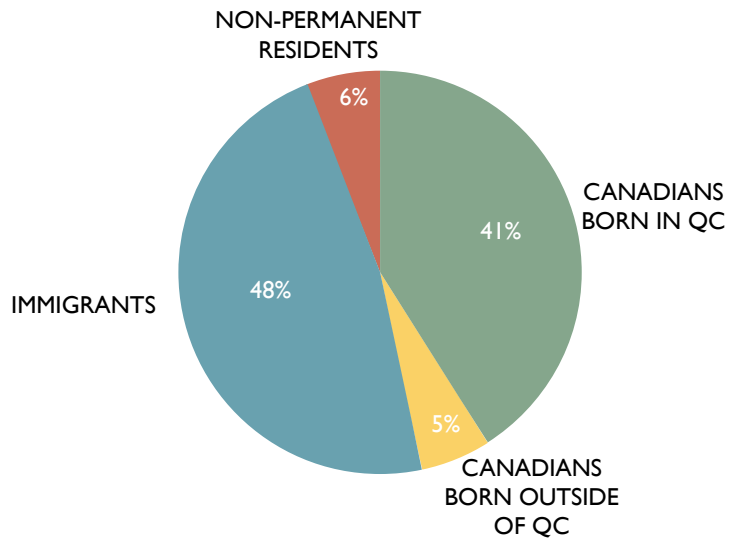

NEIGHBOURHOOD POPULATION AGE

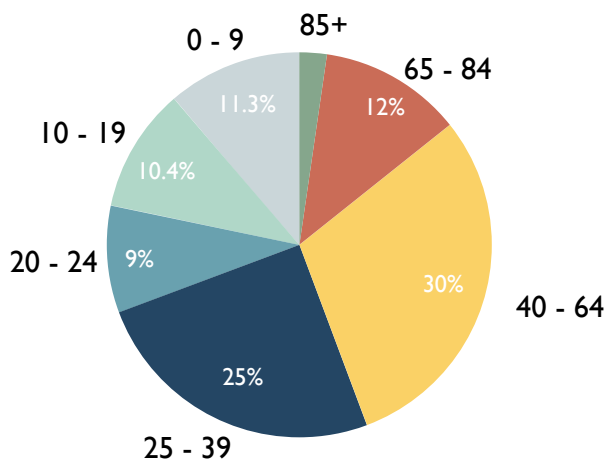

MOTHER TONGUE

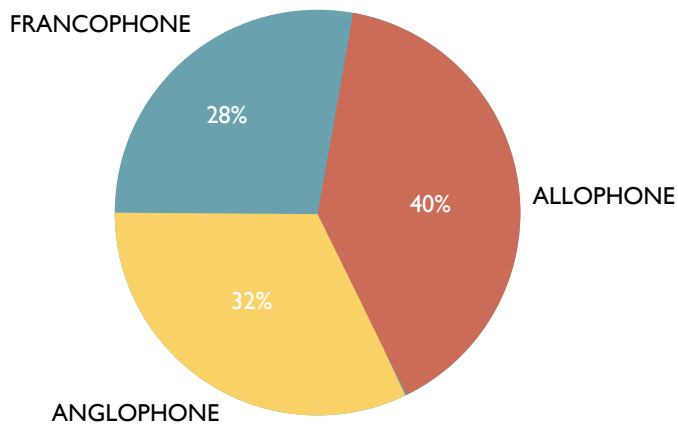

MODES OF TRANSPORT for more than $2 \mathrm{~km}$

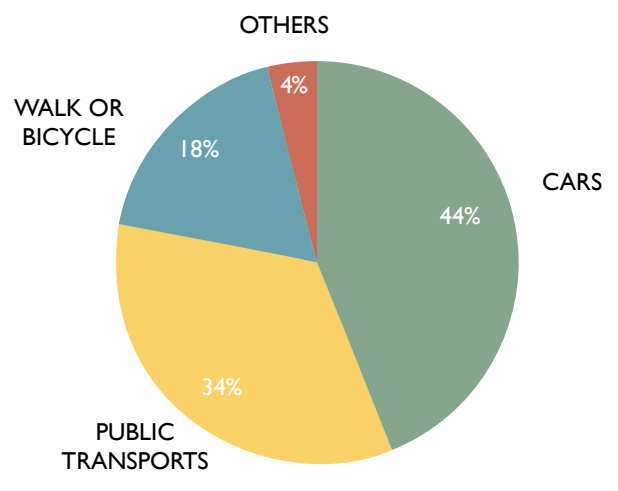

MODES OF TRANSPORT for less than $2 \mathrm{~km}$

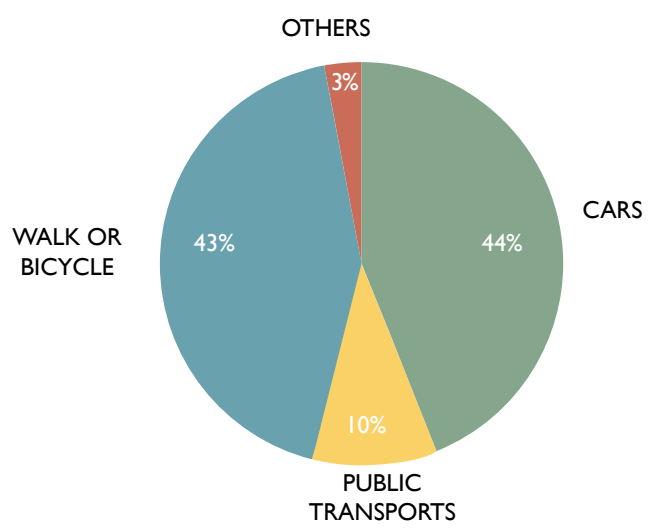

Quartier Vert Montréal 2016 


\section{The Empress Theatre}

The Empress Theatre was initially commissioned by the Confederation Amusement Ltd. After the fire in the Laurier Palace, another one of their theatres, the organization asked the architect Alcide Chausséi to design a cinema that would respect a fire protection code, which was unprecedented at the time. ${ }^{4} \mathrm{Mr}$. Chaussé then proceeded to build in 1927, a reinforced concrete theatre that could host up to 1550 spectators in its main room. Its design allowed every seat to have a clear view of the stage. ${ }^{5}$

Only a decade or so after the birth of Cinema in North America, this was at a time when movie palaces started to come into their own. North American high capacity movie theatres were inspired by the classical architecture of European palaces. The goal of these atmospheric theatres was to create an immersive experience. The spectators would not only be transported by the movie but also by the dreamy and grandiose decor. This atmospheric typology was developed by the Austrian-born architect John Eberson.

In keeping with the times, the Empress Theatre was therefore not only an innovative construction for its fire safety standards but also for its art-deco, and in this case, Egyptianinspired style. In 1922, with the discovery of Tutankhamun's tomb by Howard Carter, the Egyptian Style made its way into the decor of atmospheric movie theatres. Egypt being the border between the East and the West, it also became "the gateway from the real to the imaginary." The West became fascinated with the Orient, which evoked mystery, fantasy and magic, as well as sensuality and eternity." ${ }^{\prime \prime}$ The Oriental style was transporting the audience even further into the imaginary experience.

The front façade of the Empress Theatre, made of cast stone, was carved by the sculptor Edward Galea. The doors and windows are crowned by winged sun discs while two giant pilasters, framing the main entrance are each surmounted by some busts of the Pharaoh Ramses. Inside the theatre was truly a make-believe setting. Emmanuel Briffa, a Maltese-born interior decorator, created a spectacular Egyptian-inspired decor. From the painted panels of the river Nile to the human scale statues and the hieroglyphic ornamentation, Briffa sets the atmosphere of an Egyptian palace. ${ }^{8}$

\footnotetext{
I. Mr. Chaussé started working as an architect independently in I888 and in I900, he was hired by the City of Montreal as a building inspector. With a colleague he reviewed the construction regulations of the city. He was for this reason selected as the municipal architect in I9I4. In I9I8 he returned to private practice. Chaussé was one of the founders of the Association des Architectes de la province de Québec, which eventually became l'Ordre des Architectes du Québec. He also participated to the foundation of the Royal Architecture Institute of Canada.
}

"Chaussé, Alcide", Répertoire du patrimoine culturel du Québec, 2013. 


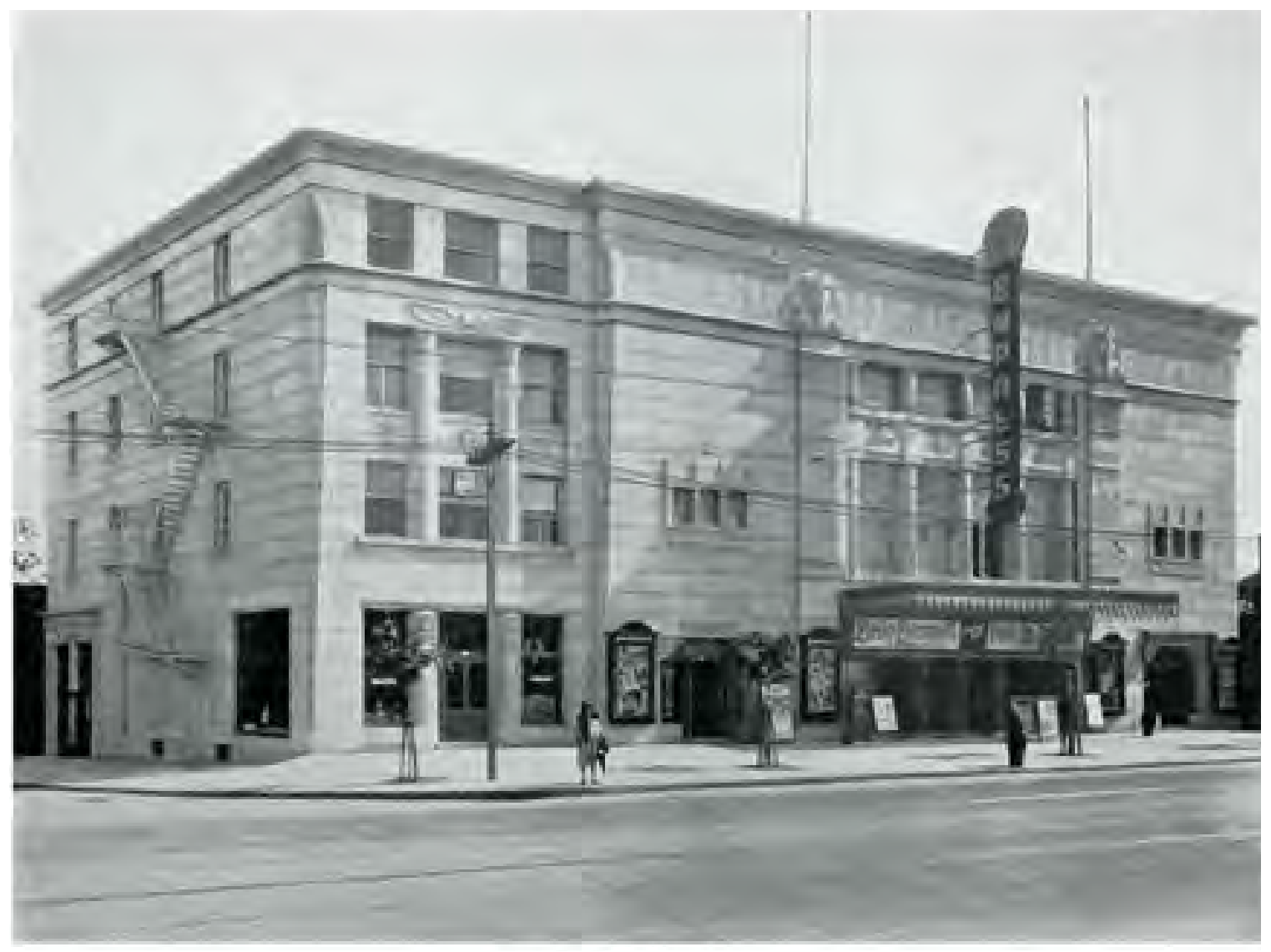

Fig. 2.5 Empress Theatre, RAIC

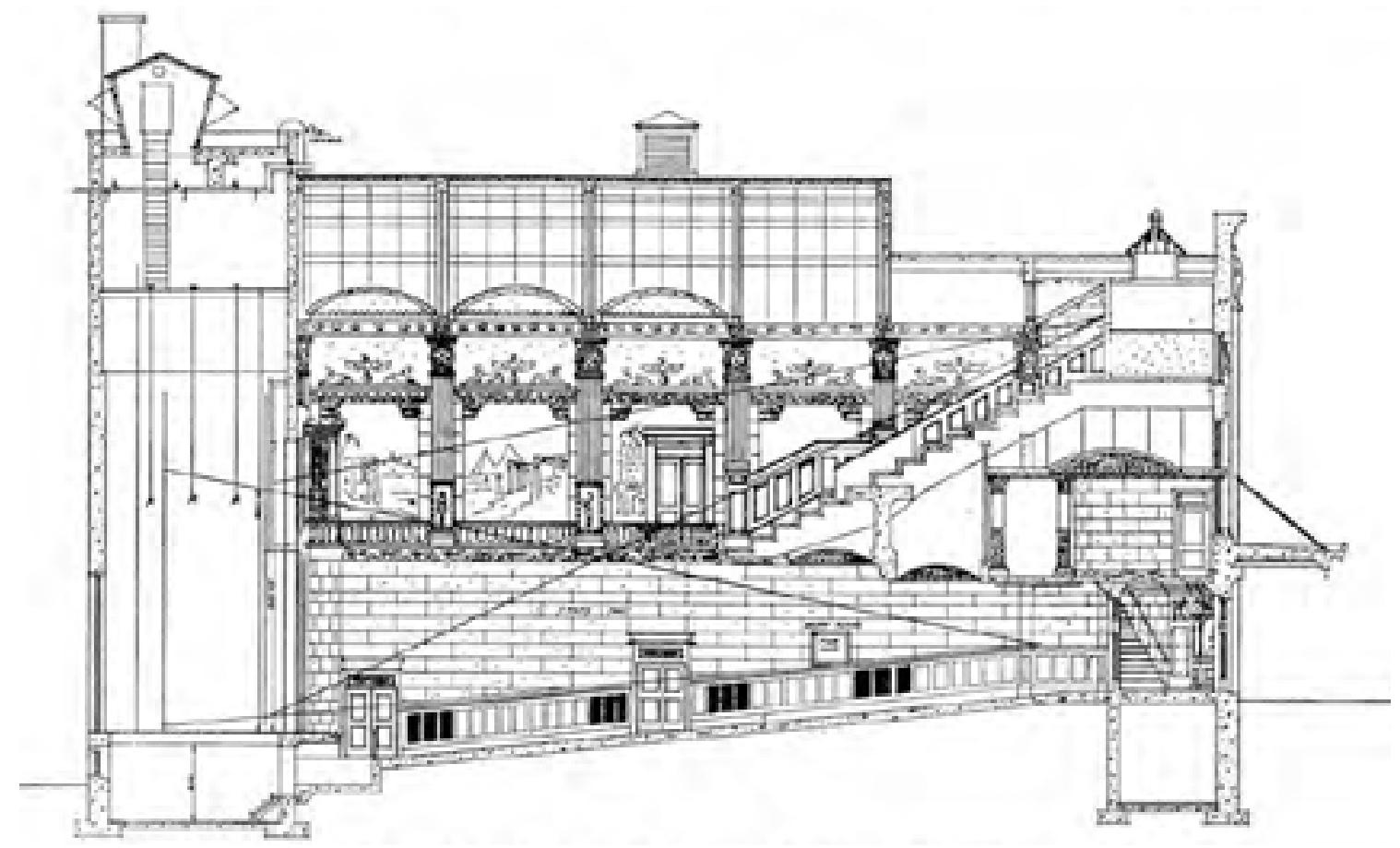

Fig. 2.6 Empress Theatre - Section RAIC 


\section{Egyptian Symbolism}

In the case of the Empress Theatre, most Egyptian elements of the façade can be directly associated with elements found on the Temple of Horus, at Edfu and the Temple of Isis at Philae, although some elements were modified. For example, the Pharaoh Ptolemy being crowned by the goddess Nekhbet, in its original temple version is accompanied by the goddess Wadjet. Wadjet is absent from the Empress' façade and therefore changes the meaning of the symbol. ${ }^{9}$ (see figure 2.6) It is believed that the second goddess was left out for space reasons. This leads me to believe that these Egyptian symbols didn't have much iconic meaning, and were intended only for their atmospheric value. Furthermore, the interior decor was completely based on Briffa's own knowledge, perception and interpretation of Egypt ${ }^{10}$, which reinforces the notion that the Egyptian elements of the theatre were simply borrowed to amplify this imaginary travel. (see figure 2.8 to 2.10 )

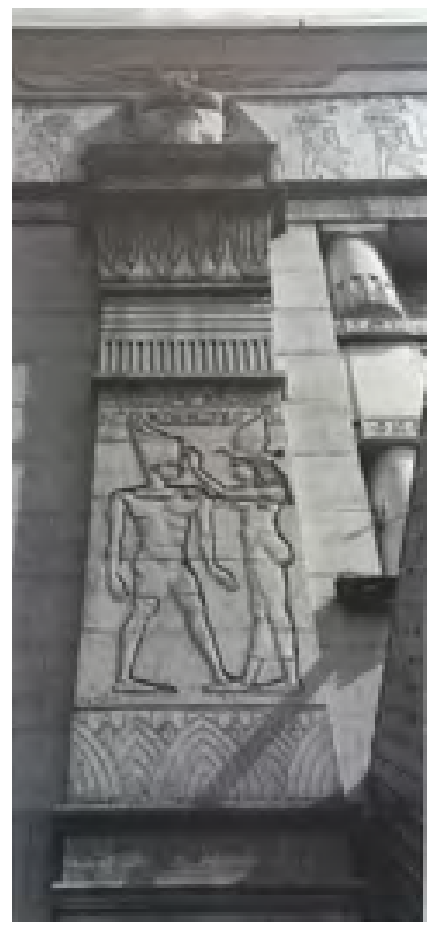

Fig. 2.7 Pharaoh Ptolemy

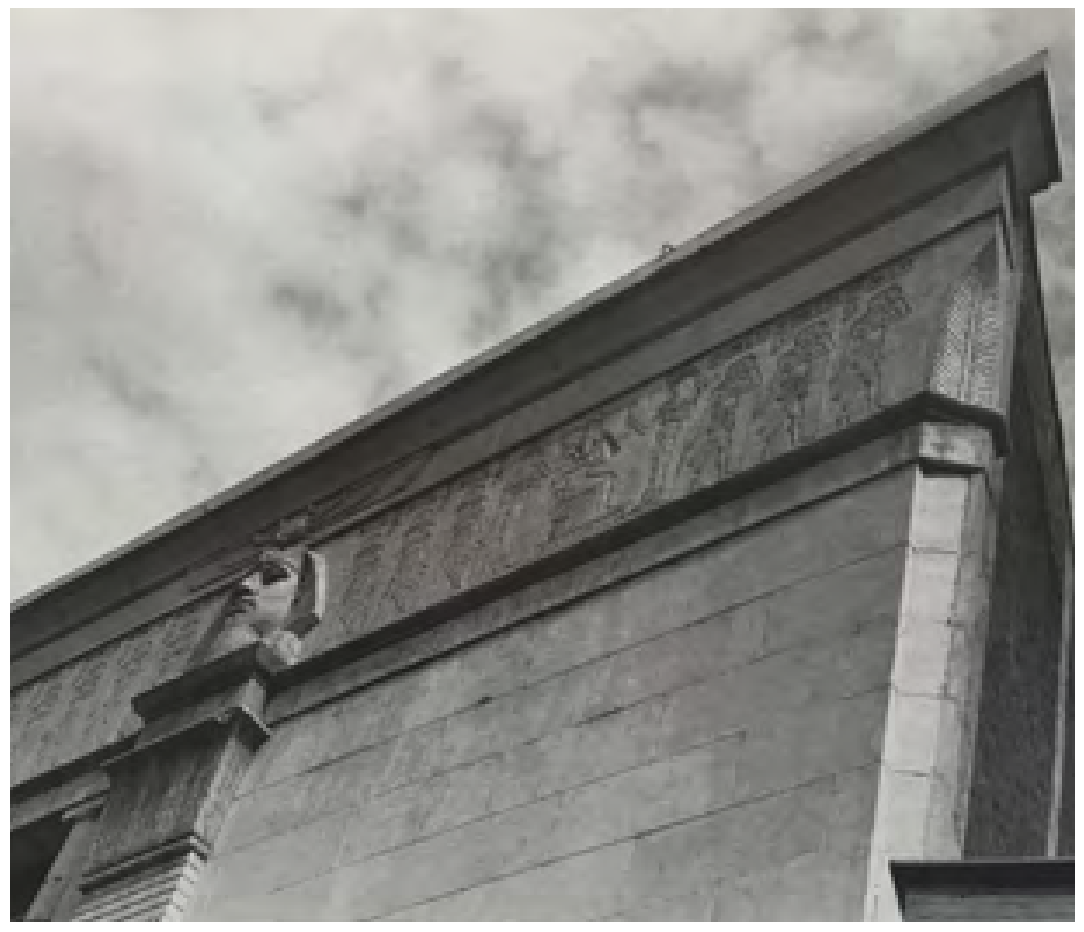

Fig. 2.8 Empress Theatre Façade 


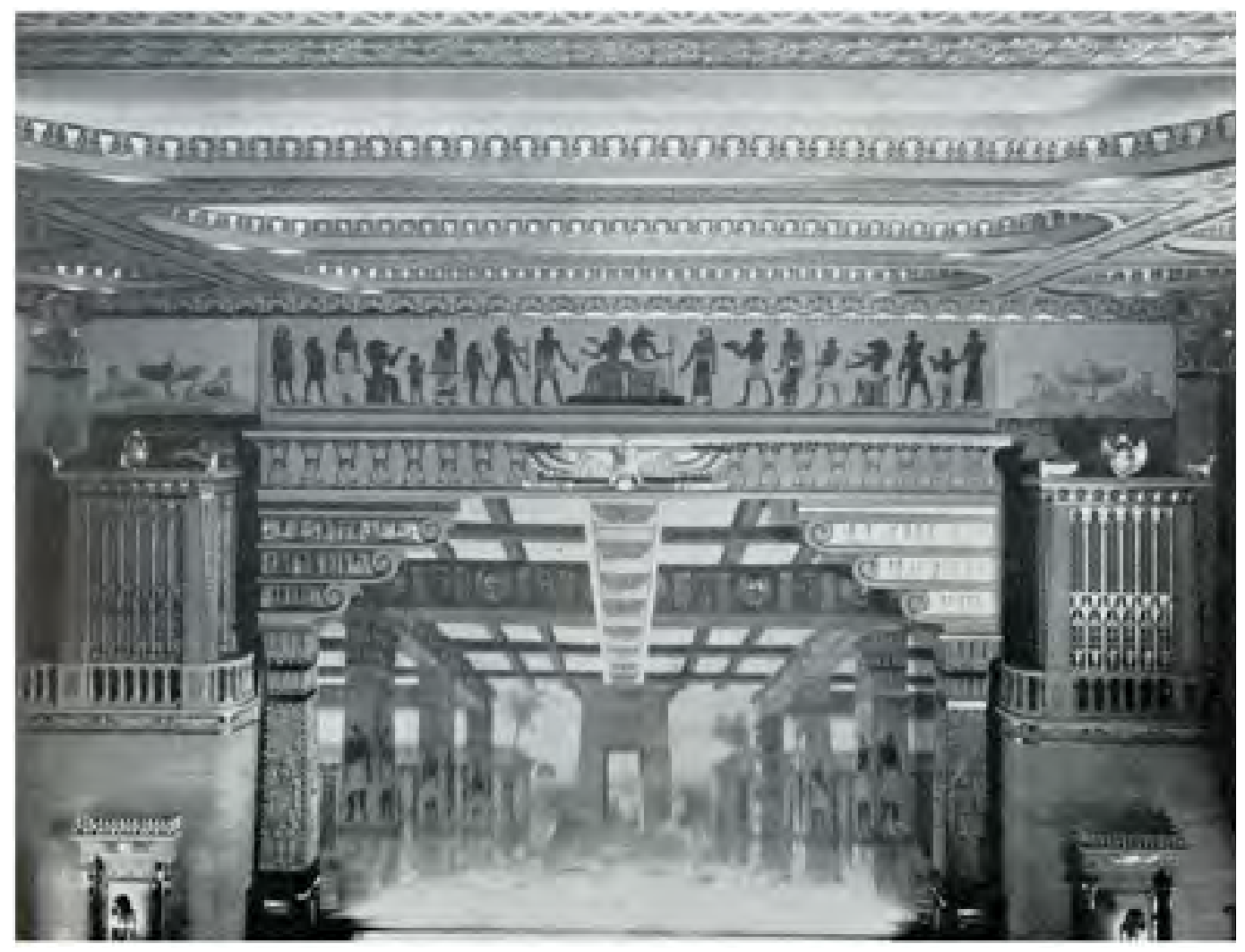

Fig. 2.9 Empress Theatre - Arch \& Curtain, RAIC

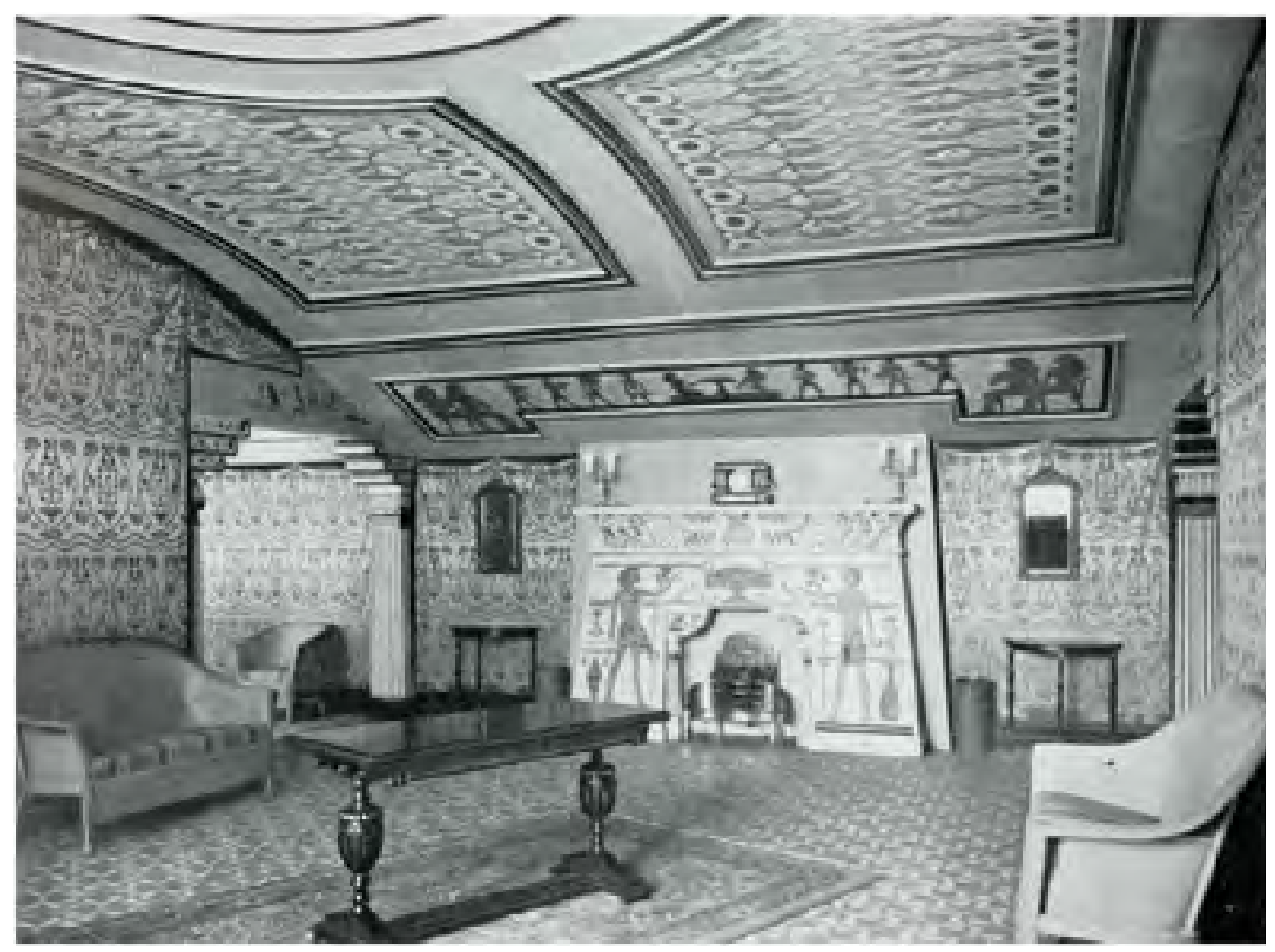

Fig. 2.IO Empress Theatre - Mezzanine Floor, RAIG 


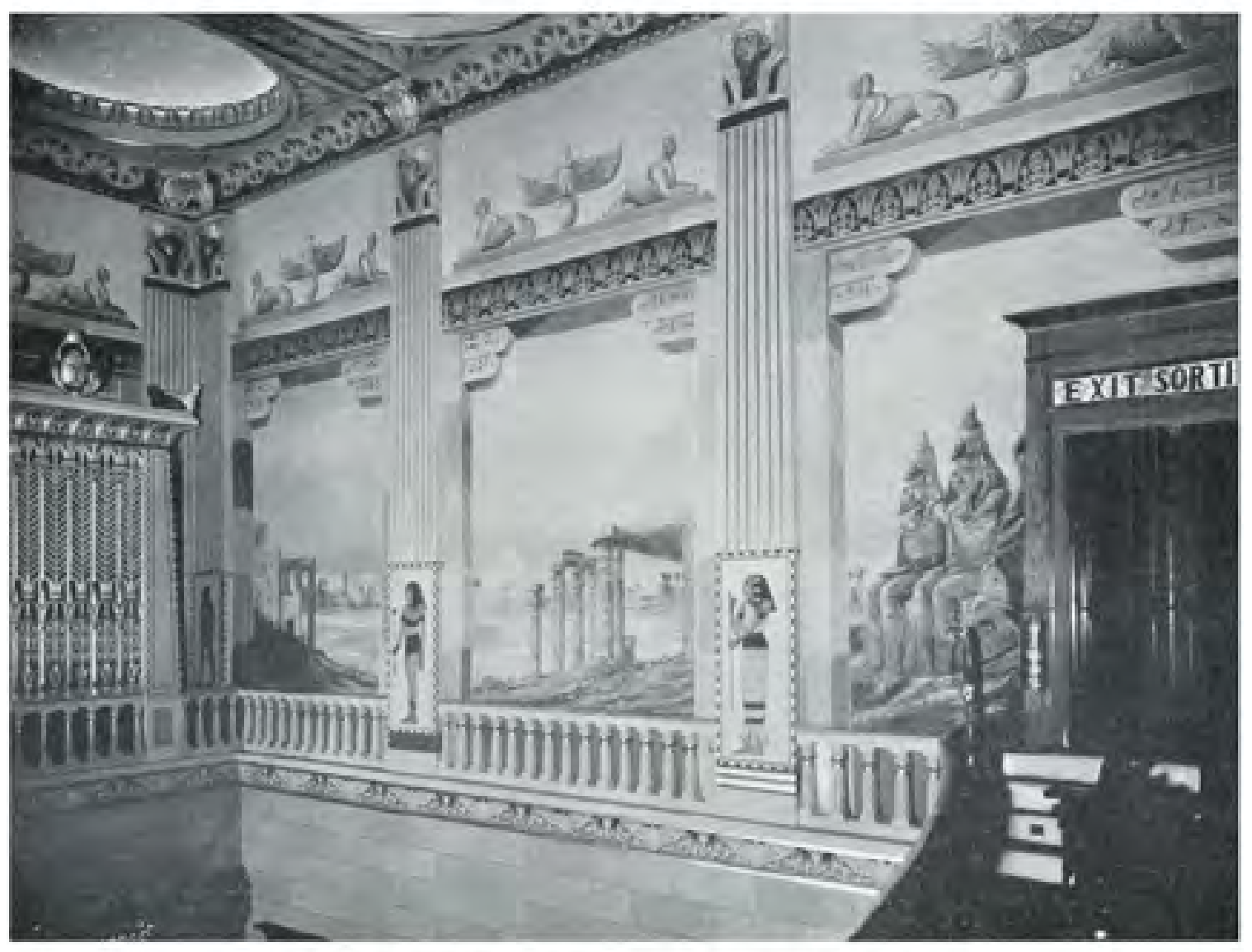

Fig. 2.II Empress Theatre - West Wall RAIC 


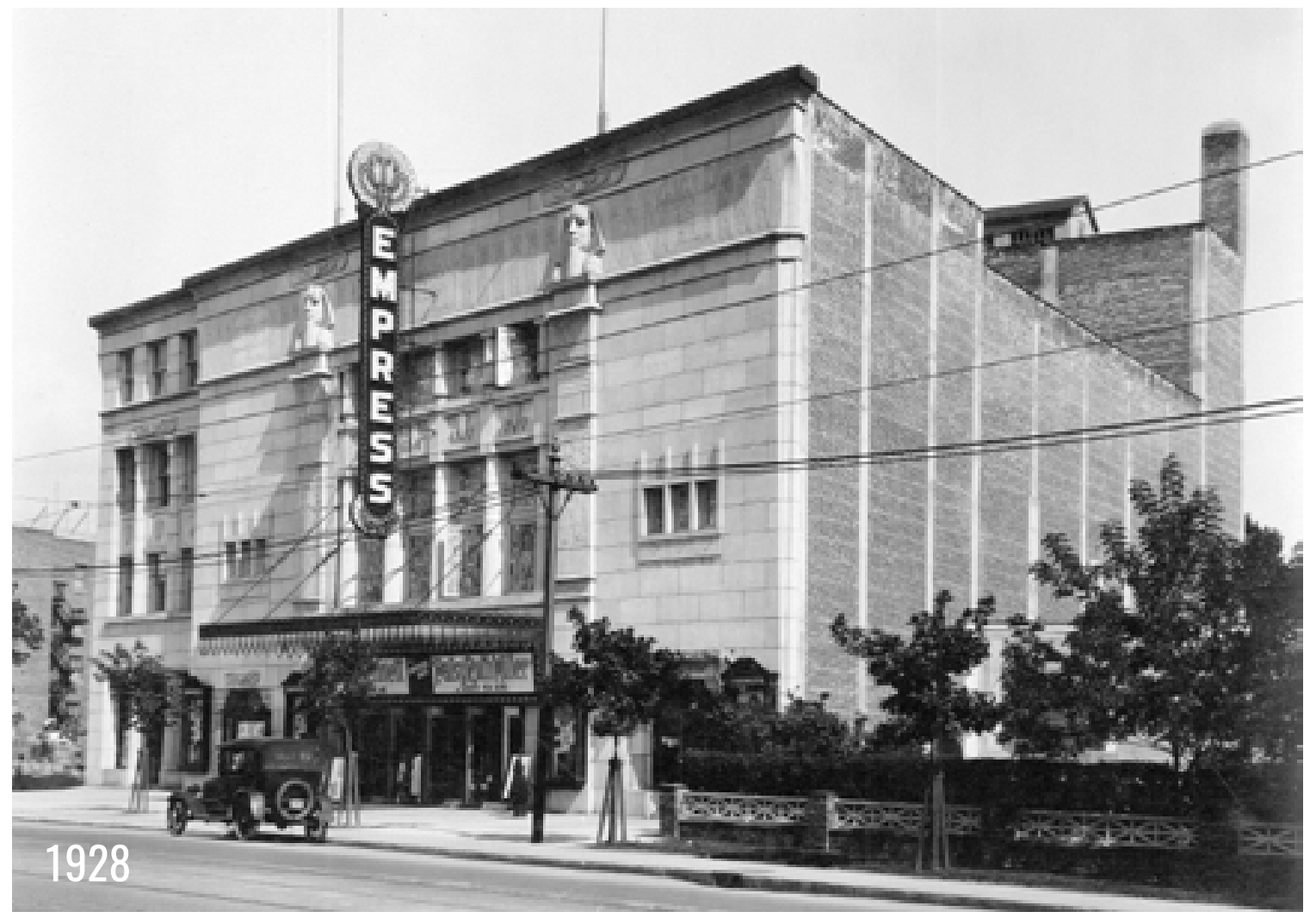

Fig. 2.I2 Empress Theatre - I928

\section{History}

For about 30 years, the Empress Theatre operated as a movie theatre. In the 60s, with the rise of television, movies lost popularity. At that time, the theatre was converted to the Cabaret of the Royal Follies, although very shortly after, in 1965, the theatre was sold again and turned back into a cinema for repertoire films. The main room was divided into two screening rooms and some alterations were done to bring the building up to date. In those renovations, some elements of the original style were either hidden or damaged to accommodate the new purpose of the theatre. The Empress then became known as the Cinema V. In 1988, the cinema was bought out by Famous Players. It ran under their ownership until 1992 when a fire took places in the theatre. It has been closed ever since.

In 1999 the city took over the building and gave it to the Corporation Cinema VI to try to reanimate it. The project fell through. In $20 \mathrm{II}$ the city took it over again to try to preserve this heritage jewel. In 20I2, the city opened a public tender. The non-profit group Cinema NDG proposed the Empress revitalization project, but for funding reasons, the project never happened. The building remains vacant to this day." 


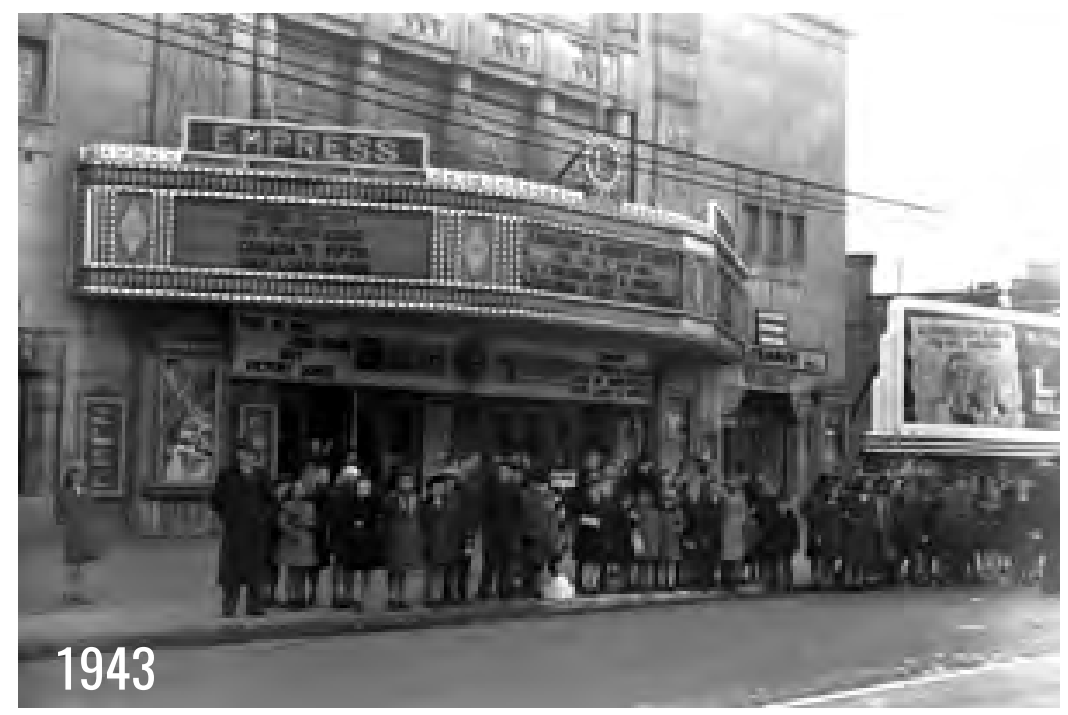

Fig.2.I3 Empress Theatre, I943

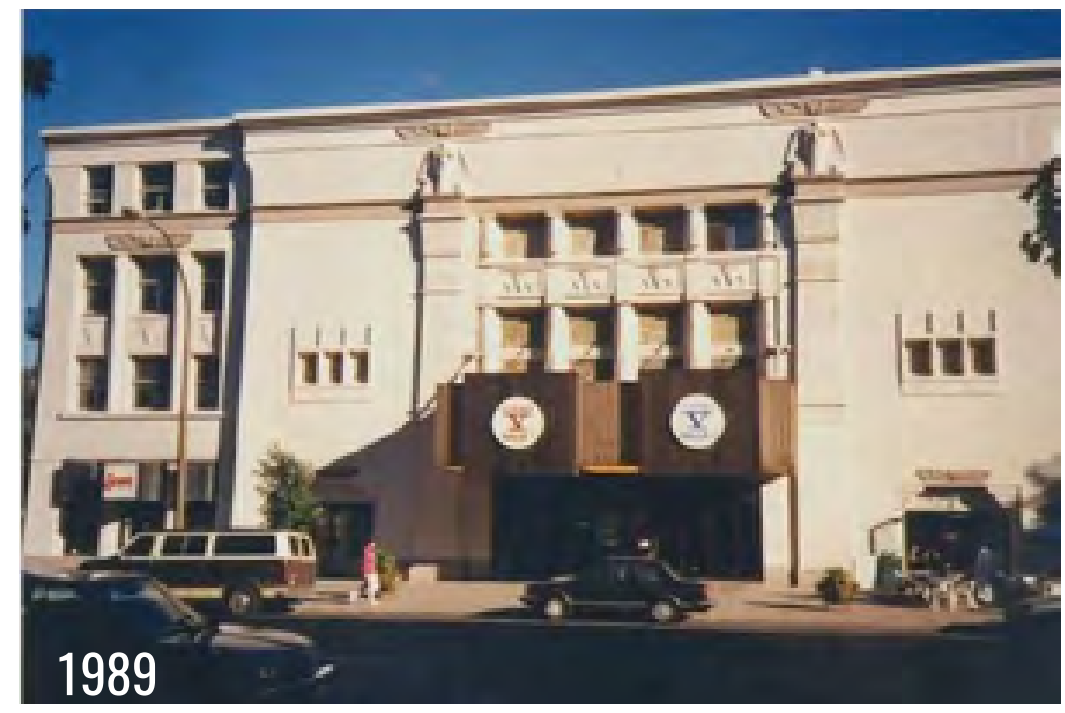

Fig.2.I4 Cinema V, I98g

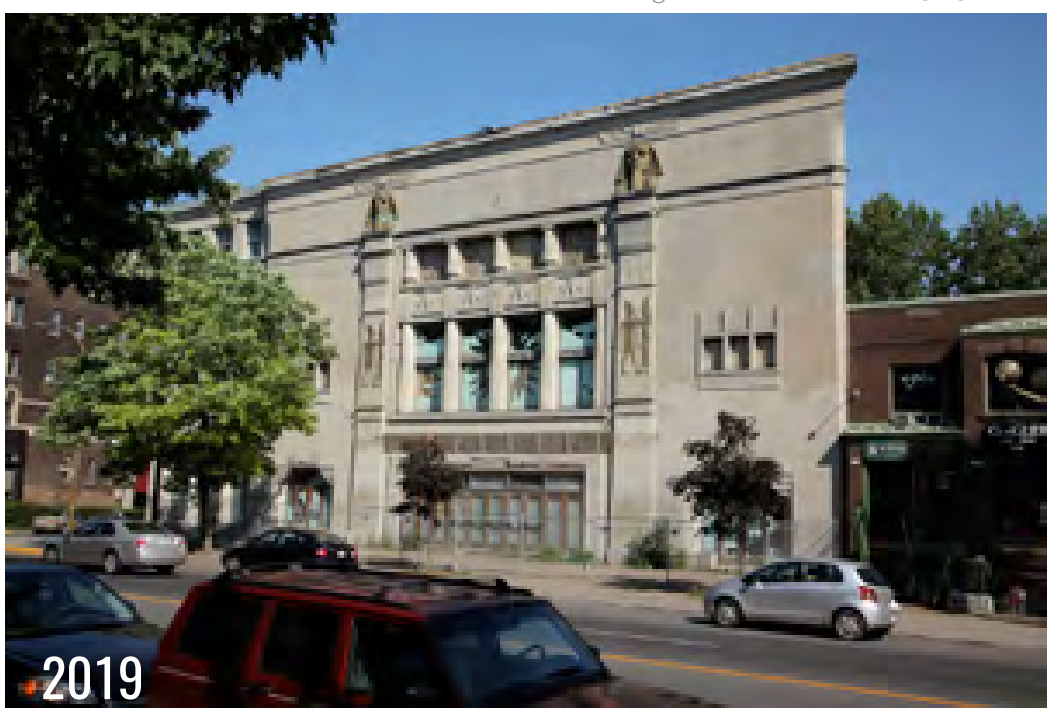

Fig.2.I5 Cinema NDG, 2019 


\section{Heritage Value}

The heritage value of the Empress Theatre was recognized in 2014 by Heritage Montreal. The value obviously comes from the unique aesthetics but also from its value in the history of movie palaces since "The Empress is the only Egyptian-themed atmospheric movie theatre of Canada."Thus the fact that Chaussé, an important architect for the province of Quebec and Briffa, a well renowned artist and interior designer, collaborated on the project makes it an icon for the city of Montreal. ${ }^{12}$

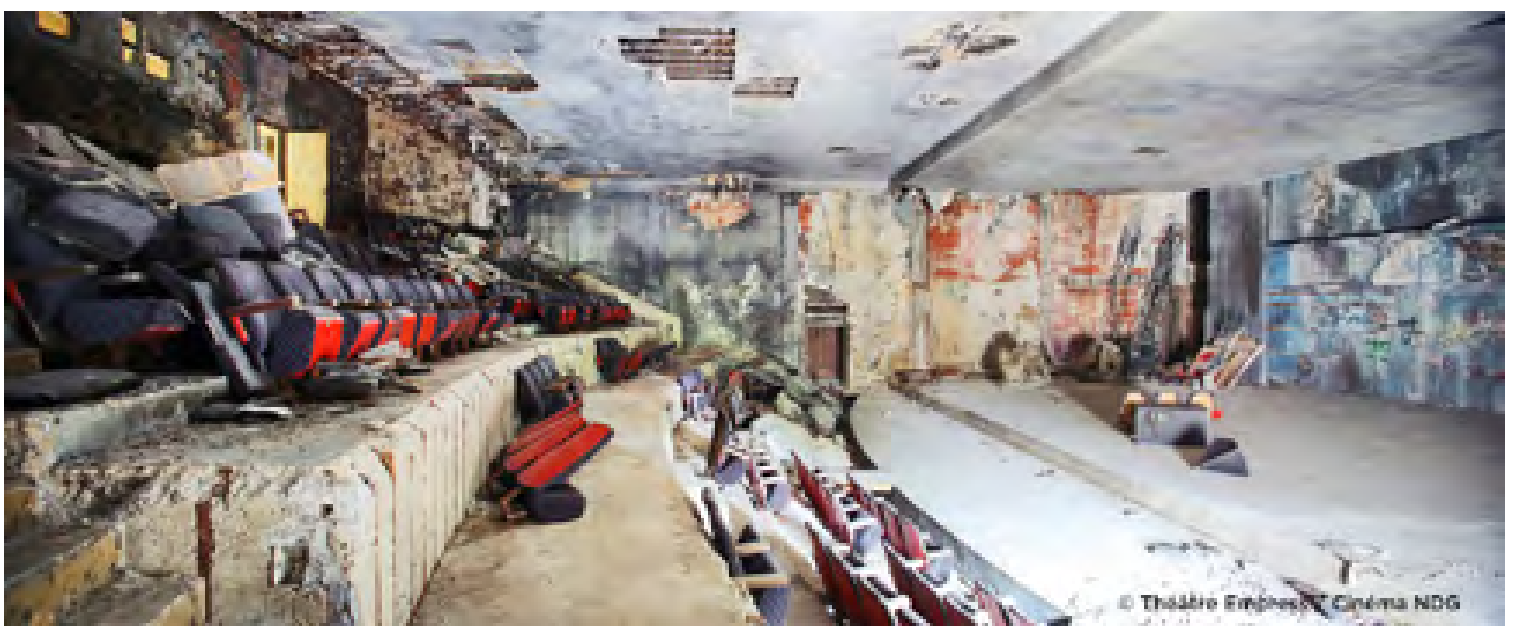

Fig. 2.I6 Ginema NDG - 20I4

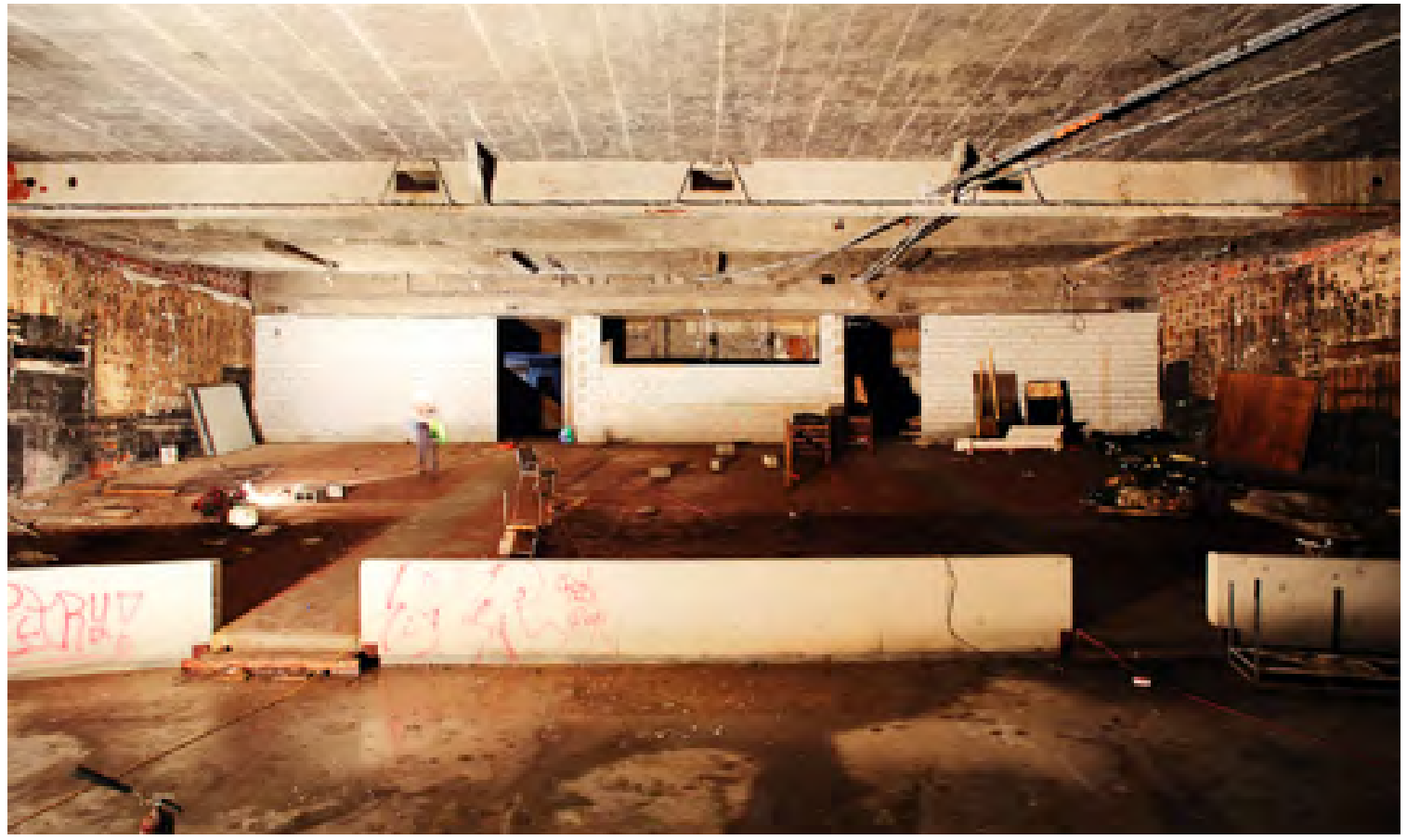

Fig. 2.I7 Ginema NDG - 2014 


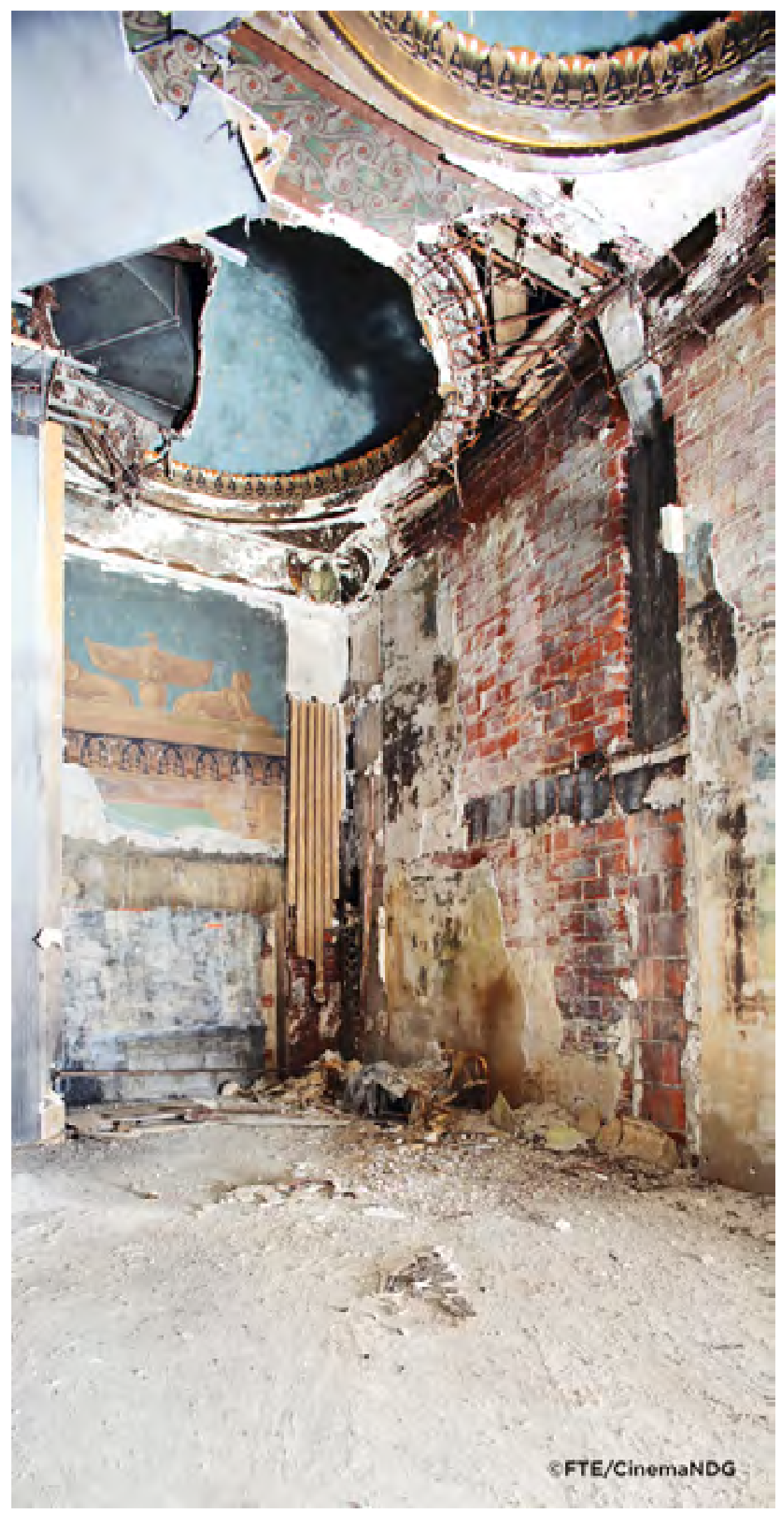

Fig. 2.I8 Ginema NDG - 2014 


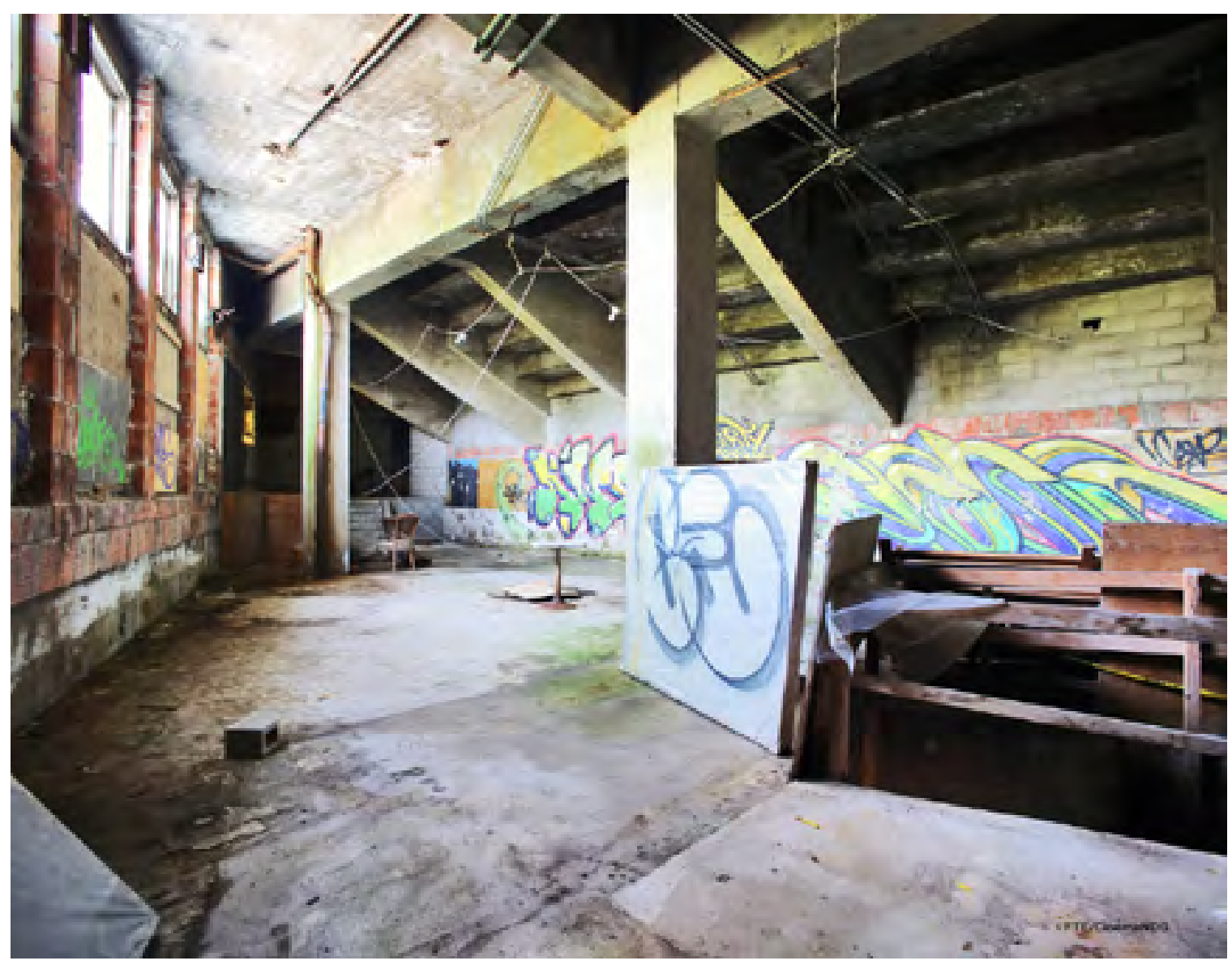

Fig. 2.I9 Ginema NDG - 20I4

\section{My take on the Heritage status of the Empress Theatre}

As you can see in the photos (fig. 2.15 to 2.18), the interior of the Empress Theatre is now in extremely bad shape, due to a lack of care from the city. Knowing that these photographs were taken in 2014, we can only assume that the situation has worsened since. Most of the decor designed by Briffa is gone, and the concrete structure of the building would definitely need to be assessed by a structural engineer. For the sake of this project, however, I will assume that the structure is in good enough condition to be used.

The heritage value of the Empress Theatre lies primarily in its façade (carved by Galea), which is only mildly damaged. I propose to restore the façade without changing its relationship to the existing structure. It is important to me that the façade remain an integral part of the project, and not a false front to a new construction.

As for the interior, considering the level of damage of the décor, and the fact that most of Briffa's work was hand painted by himself, I would propose a reinterpretation of certain meaningful elements rather than a restoration of it in its entirety. For example, some theatrical elements such as the main entrance marquee and the dome canopy in the theatre hall could be rebuilt to bring back the magic of the atmospheric theatre. 
I. Jean Laberge. Énoncé de l'intérêt patrimonial (Patrimoine Montréal, 2014)

2. Daphné Cameron. “Côte-des-Neiges - Notre-Dame-de-Grâce: deux quartiers, deux réalités”, La Presse, October 13, 2013

3. Plan du quartier vert actif et en santé NDG sud-est, (Centre d'écologie urbaine de Montréal, 20II)

4. Jean Laberge. Énoncé de l'intérêt patrimonial (Patrimoine Montréal, 20I4)

5. “The New Empress Theatre, Montreal”, RAIC, (1928), p.392-396

6. Camille Bédard."Traveling in Time and Space”, (2017)

7. Camille Bédard."Traveling in Time and Space”, (2017)

8. Camille Bédard."Traveling in Time and Space”, (2017)

9. Catriona Schwartz.“Urban Archaeology:”, CUJAH

10. Camille Bédard."Traveling in Time and Space”, (2017)

II. Jean Laberge. Énoncé de l'intérêt patrimonial (Patrimoine Montréal, 20I4)

12. Bédard, "Traveling in Time and Space”, (2017), p.

16. “Théâtre Empress / Cinéma V,” Heritage Montreal, 2016 


\section{The Project}

\section{The Proposition}

Social infrastructures as Klinenberg describes them refer to a sociological concept that describes "the physical places and organizations that shape the way people interact." He discovered them as a result of a study he conducted following the Chicago heatwave of 1995. Between July 14 and July 20 that year, 739 people died in Chicago. Looking at the patterns behind the death rates, he discovered that neighbourhoods with more poverty had higher rates of mortality. However, comparing equally low income areas, he realized that some of them had considerably lower mortality rates. When walking through these neighbourhoods and carefully studying them, he understood that this was thanks to the social infrastructures in place. Because with stronger social bonds, people had been more supportive and collaborative in this crisis. ${ }^{17}$

Although these social infrastructures are technically invisible and intangible, they are critical in shaping our interactions ${ }^{18}$. The proposed project for the Empress Theatre site imagines what shape these social infrastructures could take when becoming a neighbourhood space and building. Erik Klinenberg took specific places like libraries, daycares, schools and sports centres and studied the interactions, the connections, the relationships that were created within those institutions. He recorded them according to the type of building they were associated. Being a sociologist, however, he did not elaborate on the physical characteristics of these buildings. I, on the other hand, am interested in how these imagined or real connections and relationships are manifested in the physical world; in spatial and programatic configurations. How, for example, are physical connections made? How do we architecturally manipulate transparency or boldness, vividness or obscurity, openness or intimacy, presence or absence?

Libraries are known to be the most efficient of social infrastructures. However, the neighbourhood of N.D.G. already counts has two municipal libraries plus the ones in each school, and based on the precedent research done regarding the needs of the community, I am proposing a new kind of infrastructure that responds to other needs of the community.

Because the Empress Theatre used to be part of the social infrastructure of the neighbourhood and because it is an intriguing piece of heritage, it presented the perfect opportunity to test out if a new public facility could help weave stronger bonds within the community of N.D.G. 

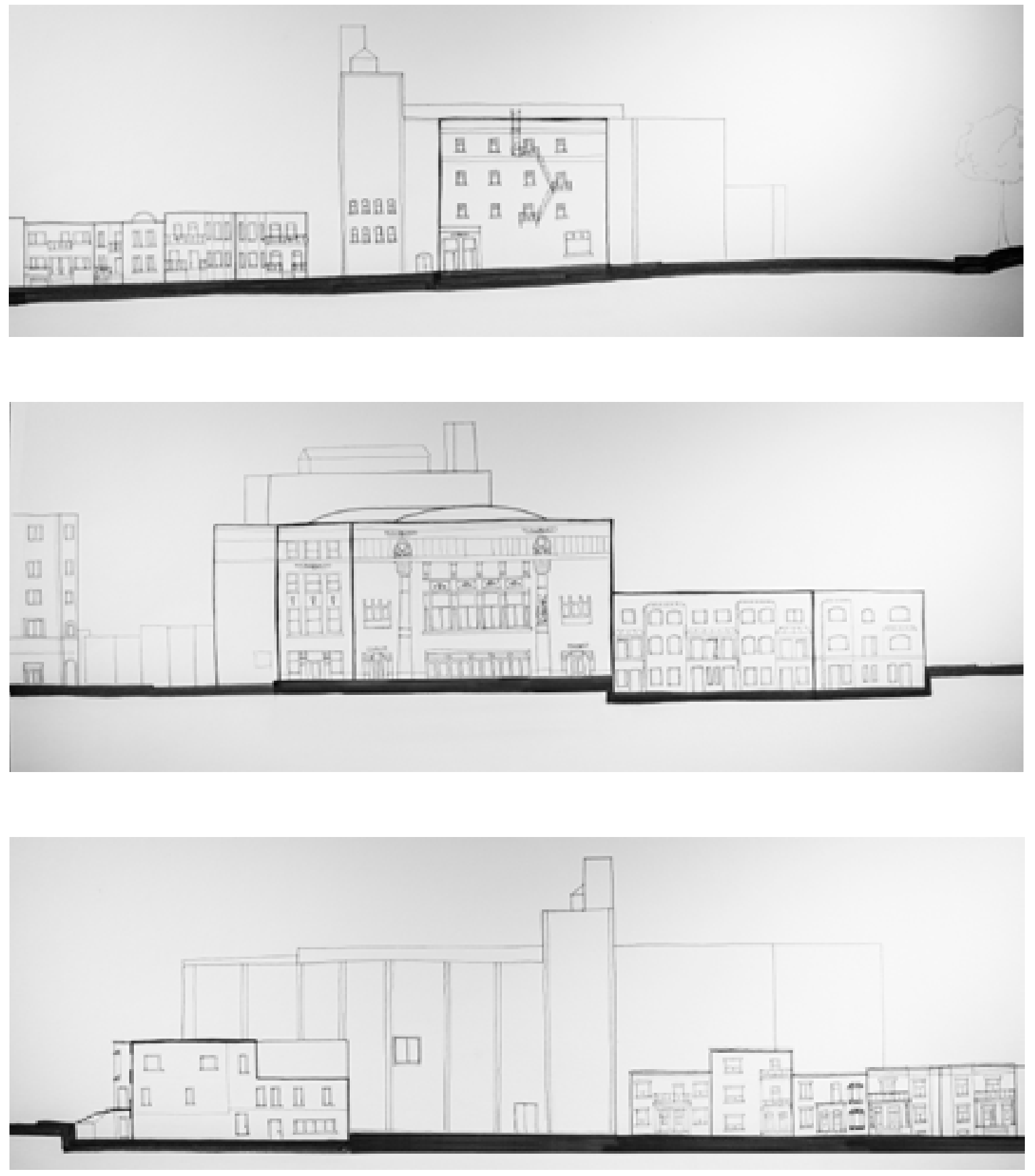


\section{The Physical}

In translating Klinenberg's sociological concepts to architecture, I reflected on what physical aspects could make it a great public facility where encounters could easily happen between members of the community; what conditions could facilitate repeated interactions betweens strangers.

First of all, the building is accessible and inclusive. ${ }^{19}$ The building aims to provide a space for differences and offers universal access to all services and facilities within the project.

Secondly, the design and conception of each space is flexible. So often buildings are designed to serve a singular, specific program and when that program becomes obsolete, the building ceases to function well, and in some cases must be demolished due to its lack of flexibility. In his book Ecological Urbanism, Mohsen Mostafavi talks about how we should promote the design of "flexible principles, that can be adapted to the circumstances and conditions of a particular location" 20 rather than designing for a fixed end result. We should think in terms of systems rather than a final product to allow our designs to evolve.

Thirdly, through their juxtaposition, spaces in the project challenge conventional relationships. Expanding upont the idea of flexibility, juxtaposing spaces promotes more diverse use of spaces. Moreover, these juxtapositions can also spark encounters that might not happen if those spaces were hermetically divided. Klinenberg states in his book "It (social infrastructure) influences seemingly mundane but actually important patterns from the way we move in our cities to the way we casually interact with strangers, friends and neighbours." ${ }^{21}$ Programmatic juxtapositions help sustain casual interactions that eventually weave the social fabric together.

Fourthly, the design allows users to linger. They are encouraged to take all the time they need to navigate and interact inside and around the building. Using the daycare's drop off as an example, Klinenberg explains that "social infrastructures that promote efficiency tend to discourage interactions". 22 If there is no room to wait, to sit and chat, then there is no room for bonds to be built between individuals. These spaces allow people to stop and contemplate, to share a story or an unexpected moment ignited by the disposition of the architecture.

Elaborating upon the idea of lingering, the project includes 'third spaces'. This term "refers to places where people spend time between home ('first' place) and work ('second' place). They are locations where we exchange ideas, have a good time, and build relationships." ${ }^{23}$ Hence, the project includes spaces where people can hang out without feeling pressured to simply consume and leave as quickly as possible. 
Finally the building creates some unexpected moments. It presents unusual details or relationships between spaces and programs that can spark conversation between users and produce moments where strangers may feel the urge to point out a surprising or unusual thing to their neighbour. Besides sparking conversation, these unique characteristics might want to make users come back to discover more.

\section{Precedents}

These projects were chosen as precedents not for their aesthetic value, which they all have, but primarily for their ethos as cultural community projects. Each one of them has for its main goal to bring the community together around culture while creatively restoring forgotten gems of their neighbourhoods.

\section{Chicago Arts and Industry Commons}

Theaster Gates, a sculptor from Chicago with training in urban planning and preservation, leads different cultural and social projects in his home town. His main goal is to "revitalize public spaces and connect people of all backgrounds, cultivate trust within communities, and reverse the trends of social and economic fragmentation in cities and neighborhoods." 24

He does so by reappropriating public and private abandoned spaces around some of the less cared for neighbourhoods of Chicago. His projects focus on local and historical culture and on giving it back to the community.

As part of the Chicago Arts and Industry Commons project, different sites and spaces are being transformed. For example, the Saint Laurence Elementary School was converted into an art incubator to help local entrepreneurs grow their businesses. The Kenwood Gardens, is going through a revitalization to give the public closer access to nature. Thus, this park will include small artists studios. The Garfield Park Power House will become a center for training in design and fabrication and will incorporate a woodworking studio and a production showroom. Finally, the Stony Island Arts Bank Campus, a former bank building, will become a cultural and artistic hub.

Theaster Gates' projects are particularly of interest because they are truly and deeply inclusive.They are designed specifically to strongly connect communities and heal fragmented social groups. Furthermore, these projects provide many different kinds of third spaces that support local economy via alternative strategies, i.e. through creation and socialization. They allow people to linger and spend as much time as they need in the space. They never encourage in and out consumerism. 

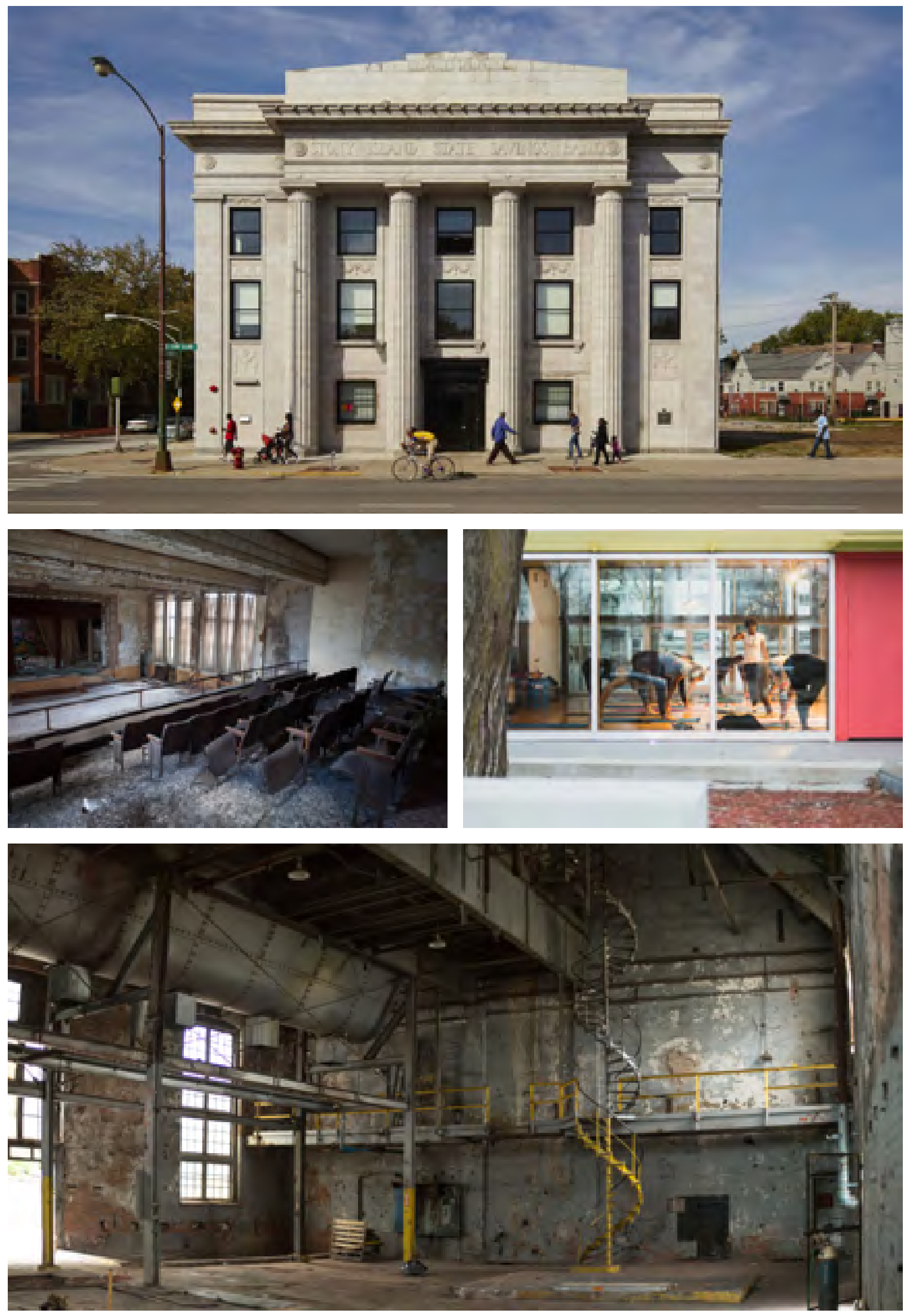

Fig.3.2 Stony Island Arts Bank, Fig.3.3 St Laurence School, Fig.3.4 DAHG, Fig.3.5 Garfield Park Power House 


\section{Granby Winter Garden}

As part of a larger urban rejuvenation project in the neighbourhood of Granby, Liverpool, Granby was one of the most economically deprived areas in the UK and many houses were abandoned. A group initiative was taken to transform the neighbourhood into "an architecturally rich, green and creative quarter".

As one of the interventions in the larger scheme, the collective Assemble has converted two row houses into a secret indoor garden. These houses had collapsed, leaving the space open and the adjacent masonry exposed. The project includes a triple height open garden space in which full-height trees can grow and also a space for potting and propagation. This beautiful space can also be opened to the backyard to host some community barbecues.

As Assemble wanted to promote creativity, sustainable local enterprise and encourage community activities, the project also includes different event spaces and some studios for artists' residences. These can also be rented by the public to finance the garden and the events hosted there. In the second house there is a community kitchen on the ground floor and above are other common rooms and a project space. Assemble said about this project "We hope it will be a place that brings about wonder and delight but feels open and welcoming, an alternative to the drab spaces that can characterize low budget community projects." 26

Once again, the Granby Garden project had for its main goal to be inclusive and invite all members of the community to participate in their own way in this project. The juxtaposition of various programs under the same roof makes it an ideal precedent for the Empress Theatre project. In addition, the fact that Assemble itself describes this garden as "secret" confirms the celebration of the unexpected quality of a magically garden hidden behind a regular house façade.

Fig. 3.6 Granby Winter Garden Axonometric

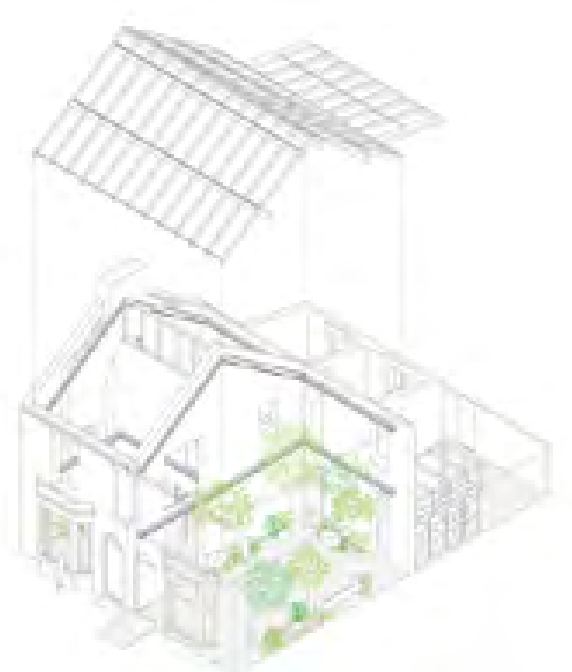



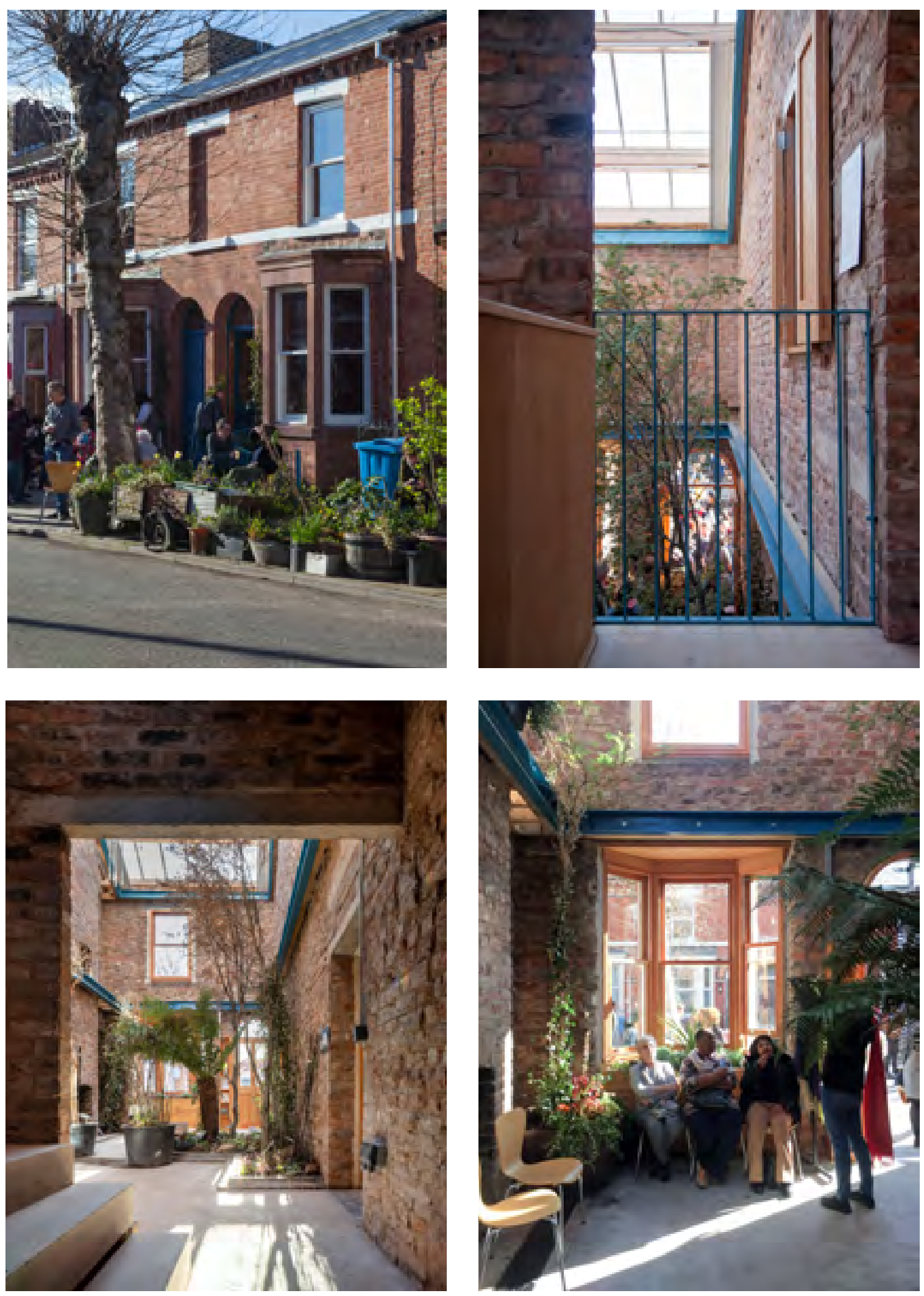

Fig. 3.7, Fig. 3.8, Fig. 3.9, Fig. 3.IO Granby Winter Garden 
Sala Equis

Sala Equis was formally an erotic theatre but it was recently refurbished into a new multipurpose theatre. The designers of Plantea Studio kept its original purpose as a cinema but redesigned it in a more flexible way to allow it to host different kinds of activities as well. Therefore, the theatre was subdivided into smaller rooms with very different ambiance to serve different purposes and the main room serves as a public plaza. This room, for example, can host music performances, talks and exhibitions and guests can enjoy all of it with food and drinks, served in house. Furthermore, some of the furniture is design specifically to encourage a more collective experience. This facility was designed with the hope of giving visitors the feeling that in this place "things happen spontaneously". ${ }^{25}$

I first looked into this project because like the Empress Theatre, it involved the refurbishment of an old movie theatre. But the fact that design focused specifically on being inclusive and flexible made it a strong reference for this thesis. Moreover, renovating an old erotic theatre and giving each room a different atmosphere underlines the value of introducing the unexpected into a project.
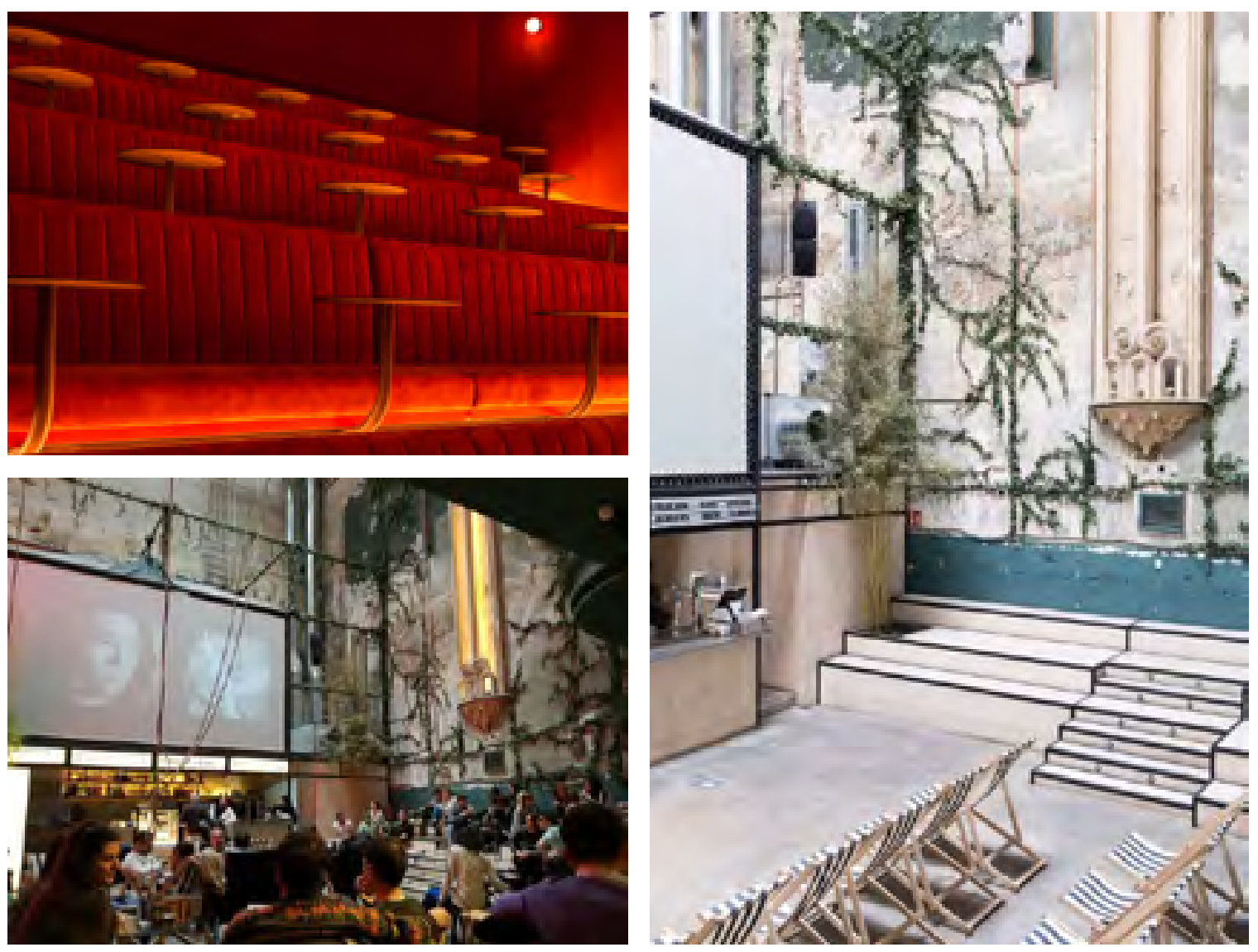

Fig. 3.II, Fig. 3.12, Fig. 3.13 Sala Equis Theatre 
Bâtiment 7

After 15 years of disputes, the Bâtiment 7, which was a former CN train shop, is now open in Montreal's Point-Saint-Charles. This project is meant to be a hub of services and culture for a neighbourhood that previously was lacking this kind of interest. The building now offers a grocery co-op, a brew pub, many different artists studios, a communal space, a wood workshop, a metal workshop as well as a co-op bicycle and car repair services. The building also offers a long strip for community gardening along its side. It is meant to be universally accessible, to offer an ecosystem of learning and experimenting and it is managed with a horizontal governance model. The project also focuses on fighting gentrification and profitdriven development.

In the future, the organization hopes to develop a daycare and family center and a food hub in the adjacent $\mathrm{CN}$ buildings that are still sitting empty. ${ }^{27}$

This project was particularly interesting to me because it also takes place in Montreal and is a proof that these kinds of alternative projects are challenging but possible to build. As in the previous case studies, inclusivity was one of the driving forces that built this project. It also demonstrates flexibility as it can adapt to the different activities hosted by the community and it definitely provides great and various spaces in which to linger. I myself have spent many hours inside and outside this project without feeling any pressure to leave at any point. Third spaces are definitely a great part of this building.

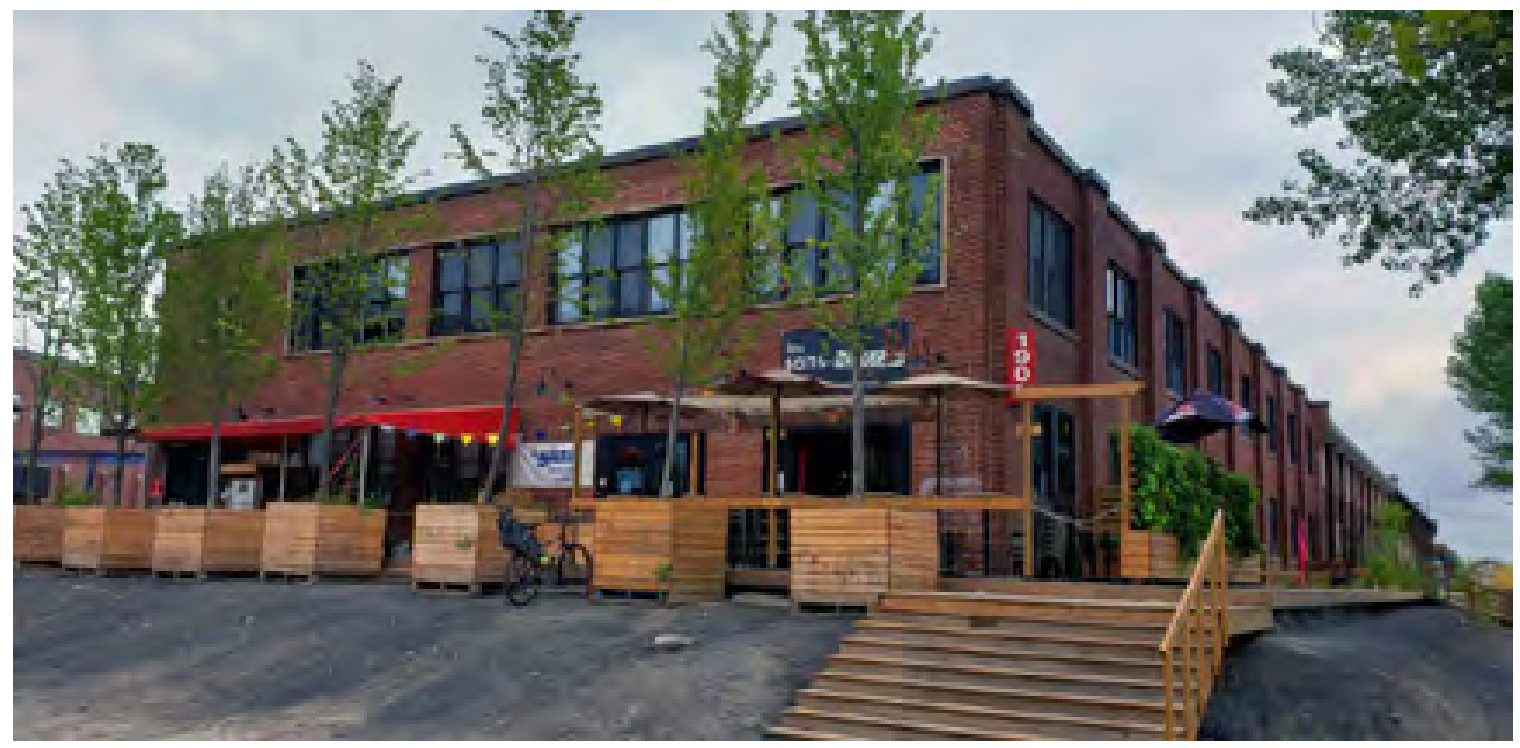




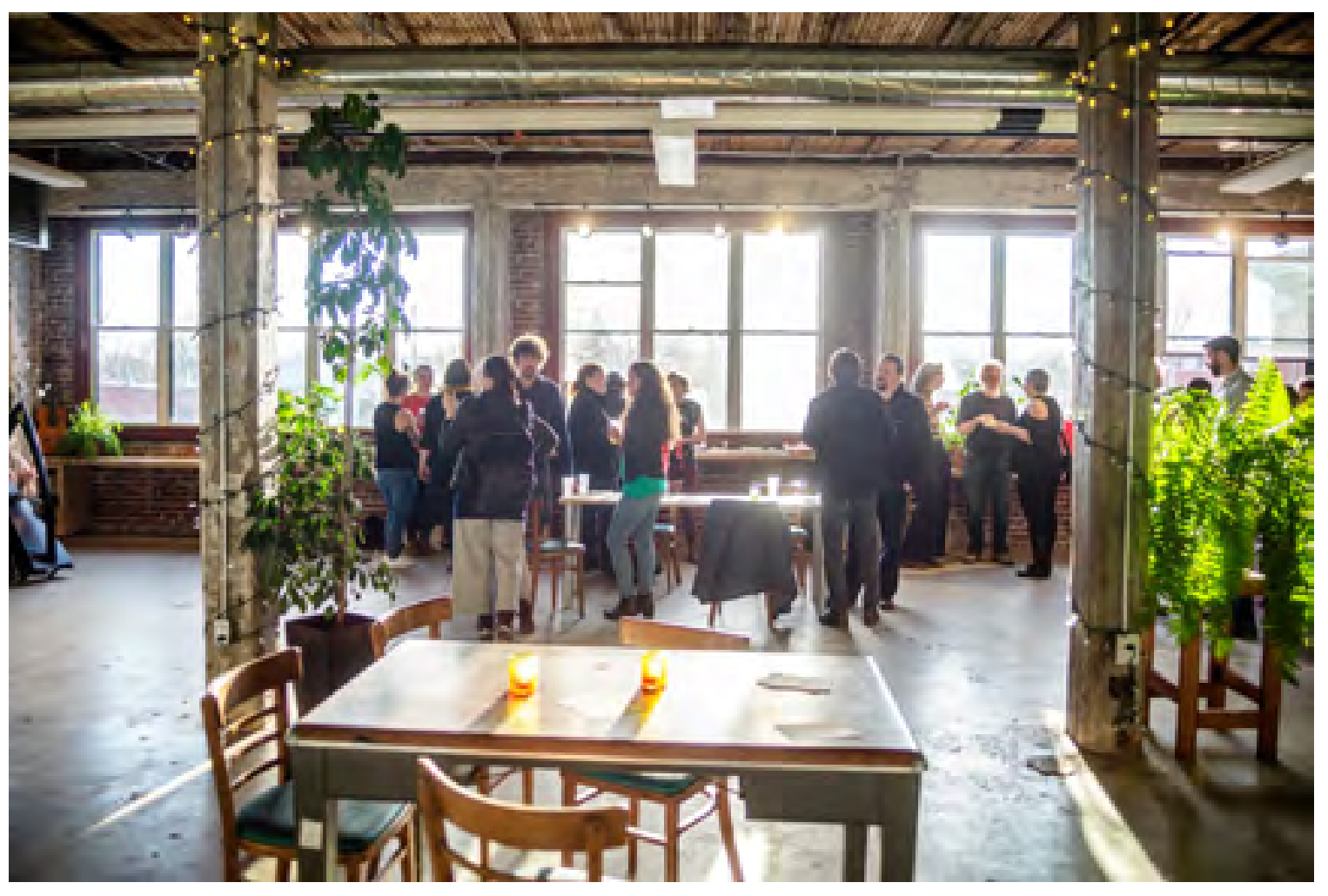

Fig. 3.I5 Bâtiment 7 
17. Eric Klinenberg, Palaces for the People (New York: Crown, 2018), 2-7.

18. Eric Klinenberg, Palaces for the People (New York: Crown, 2018), 27.

19. “What Makes a Successful Place?,” Project for Public Spaces, January, 2019, https://www.pps.org/article/grplacefeat

20. Mostafavi, Mohsen and Gareth Doherty. "Why Ecological Urbanism? Why Now?" in Ecological Urbanism (Harvard University Graduate School of Design with Lars Müller Publishers, Cambridge, 2010)

21. Eric Klinenberg, Palaces for the People (New York: Crown, 2018), I4.

22. Eric Klinenberg, Palaces for the People (New York: Crown, 2018), 18.

23. Stuart M. Butler and Carmen Diaz " 'Third Places as Community Builders' ",Brookings, September 14, 2016, https://www.brookings.edu/blog/up-front/2016/09//4/third-placesas-community-builders/

24. Theaster Gates, "Chicago Arts and Industry Commons", Projects, 2019, https://www.theastergates.com/project-items/chicago-arts-and-industry-commons/ images?view=thumbnails

25. Natashah Hitti,"Plantea transforms defunct erotic cinema into contemporary art-nouveau theatre", Dezeen. November 2018, https://www.dezeen.com/20 I8/I I/29/plantea-cinemaart-nouveau-madrid/

26. Lizzie Crook, "Assemble transforms two derelict terrace houses into Granby Winter Garden”, Dezeen. April 2019, https:/www.dezeen.com/2019/04/26/assemble-granbywinter-garden-architecture-liverpool/

27. Bâtiment 7.“Our mission.” About. 2018. https://www.batiment7.org/en/about/ 
The Program

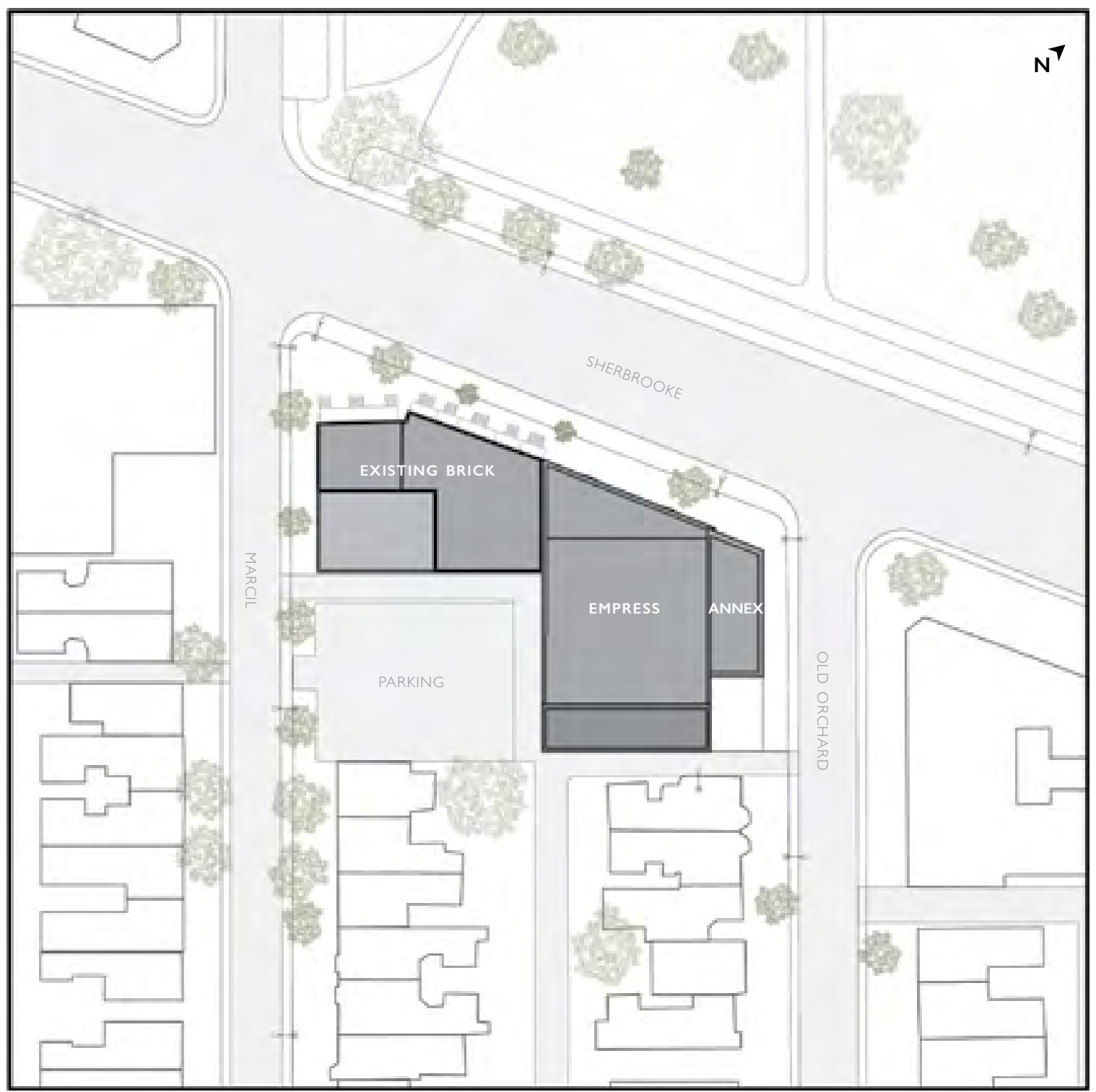

Site Plan Before Intervention 


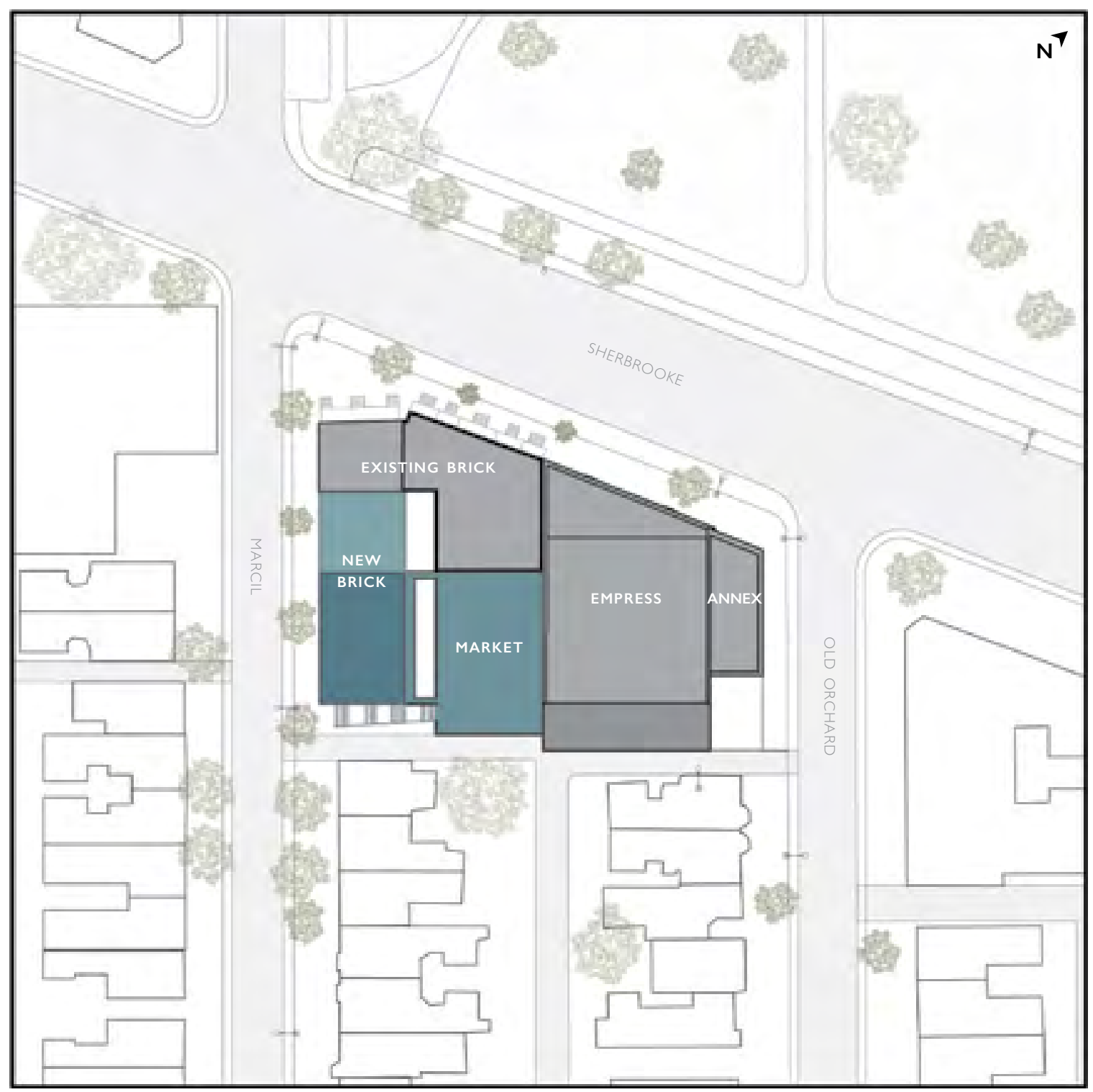

Site Plan After Intervention

EXISTING BUILDINGS

NEW INTERVENTIONS

Fig. 4.2 Site Plan After 


\section{The Annex}

The Annex is part of the original building designed by Mr. Chaussé. In his original scheme, the ground floor was meant to be a commercial space and the three floors above were apartments. Today the structure is still in good condition but all the partitions are in rough shape. Therefore I propose to simply renovate these interior spaces, keeping their original purpose while adapting them to current needs. (see figure 4.1)

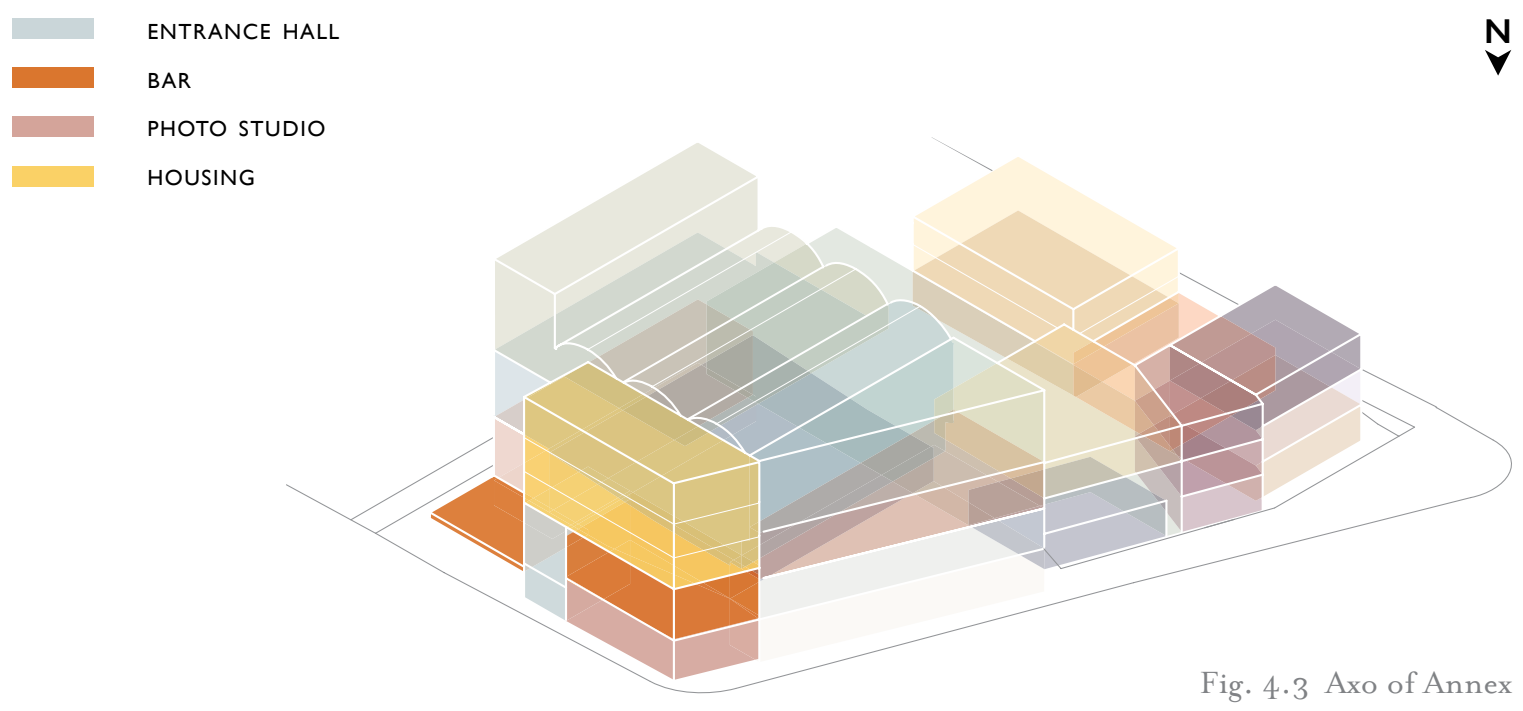

The Bar

The entrance of the bar is located on the North-East corner of the site. From the inside the bar is connected to the main lobby. This way, when people come to see a play and they arrive a little early, they can have a coffee or drink while waiting for the theatre hall to open. Or if some friends want to linger and discuss after seeing a film, they can do so at the bar. From the inside of the bar, a large inner window gives a nice view of the stage and the screening space. When the room is being used for a different purpose like a conference or a stand up comedy night, this window can be opened to offer a few more seats and a different perspective on the performance. On the other hand, if a movie is on, a tinted glass can be pulled or shutters can be closed, so as not to disturbed the projection.

In the summertime, a "terrasse" can be enjoyed at the back of the building. Customers can enter either from the front on Sherbrooke street or from the back on Old Orchard. The terrace also has a direct access to the screening space, which allows users to go straight to their movie after having a refreshment on the deck. 
The Apartments

Above the bar are three apartments. Two of them have three closed bedrooms and one has two, each with an open living area with dinning room, living room and kitchen; good for small families or roommates. They share a common entrance on Old Orchard street. The two bedroom apartment is slightly smaller because some of the space is taken up by the emergency exit of the theatre. This allows for a small shared office space on the first floor, which can be used by kids to do their homework together in the evening or by any tenant who needs a calm area in which to work.

Like in the bar, the three apartments each have a window that looks into the theatre hall. Although in contrast to the one in the bar, these ones get some daylight from the greenhouse sitting on top of the theatre. Once again, depending on what is going on on stage, these openings can either be open or closed according to the performance taking place in the theatre. These windows act as traditional balconies, although in these cases, the spectators can enjoy the show from the comfort of their home.

The Photo Studio

In the basement, below the bar, is a photography studio. Being a windowless space makes it perfect to control artificial light, either for shootings or to develop photos. This space, like the other "professional workspaces" in the project, works as a coop. People can become members and use the space in exchange for equivalent hours of volunteer work to maintain the studio.

\section{The Empress}

The Main Entrance

The main entrance of the Empress Theatre is on Sherbrooke street, straight across from the park. A new marquee has been designed to emphasize the fact that the theatre is back, but also to extend the indoor entrance hall to the outdoors. The original design of the theatre had a large marquee and therefore the sidewalk is much larger at this point, specifically to provide this public entrance space with a comfortable overhang.

Once inside the hall people are faced with the main ticket box, which also serves as the information kiosk for the centre. From there users can access the two projection rooms, the bar and the foyer for the theatre on the floor above. 


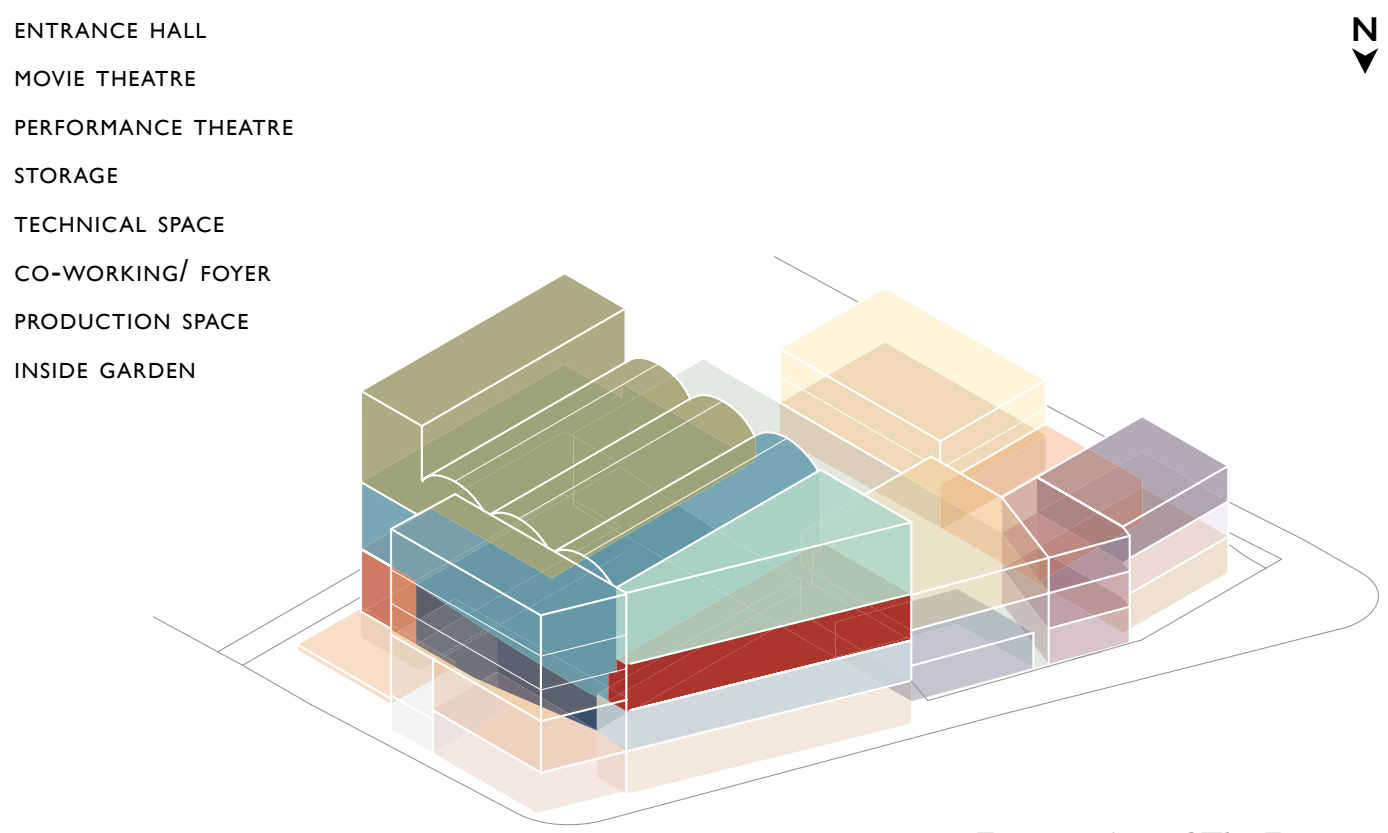

Fig. 4.4 Axo of The Empress

The Cinema

The screening room is in what use to be the lower part of the original theatre. This space is dark and has lower ceilings to allow the spectators to be really immersed in the movie or performance they are watching. The furniture is designed to be comfortable but also for couples or small groups to sit together to provide a more communal experience. The projection room has a direct public access to the bar terrace as well as the market because guests are invited to use those facilities before events or movies and bring their consumables in the projection space with them.

\section{The Cinema Production Room - Co-working}

Since the theatre was divided into two smaller rooms, what use to be the backstage on the lower floor is now an empty space sitting behind the projection screen. This will now be a co-working space but specifically reserved for professional and amateur cinema production. This would not only be a work space for individuals, but also a place to exchange knowledge and share experiences in the field of cinematographic creation.

\section{The Foyer - Co-Working Space}

On performance nights, this space acts as a classic theatre foyer, that is a place where people can congregate before, during the intermission, and after the performance, have a refreshment and discuss. When there is no performance, mostly during daytime, this area can be used as a co-working space for people of any field. The space can also be reserved for educational purpose. 
The Theatre

The main theater room is rehabilitated as a classic performance hall to honour the designs of Mr. Chaussé and Mr. Briffa. The wooden domes above the stage are restored to recreate the magical atmosphere, and at the same time create a cavity on each sides of the stage to install lighting equipment that is not visible to the public. At the back of the building is a classic backstage with a green room and space to maneuver the decors. Behind the seating area is the technical booth, which is considerably larger than usual, to offer the possibility of welcoming a larger group for educational purpose.

The Indoor Garden

Above the performance hall sits the new indoor garden. This greenhouse can be accessed either by the staircase and elevator behind the stage or from the entrance outside on Marcil street. Above the backstage is a space reserved for potting, maintenance and storage of gardening equipment. Above the stage is the actual garden. This space, is divided into smaller areas by low brick walls that become planters. These planters are organized in an organic yet orthogonal way. Similarly to ancient Egyptian gardens, they are distributed around a pond, which is actually a tank collecting rainwater from the glass canopy.

This space is open to the greater public and although the tip of the greenhouse can be seen from the sidewalk, it is at the same time a secret oasis. People are welcome to come enjoy the garden at anytime and it is maintained by volunteers from the neighbourhood and users of the whole project.

\section{The Existing Brick Building}

Next to the Empress theatre sits a multifunctional three-storey brick building. This building is in good physical shape although, for many years the different businesses that have rented the commercial spaces have struggled to stay open. For this reason, I propose to renovate this building from the inside and as well as the back façade, to be able to welcome new programs, better adapted to today. 


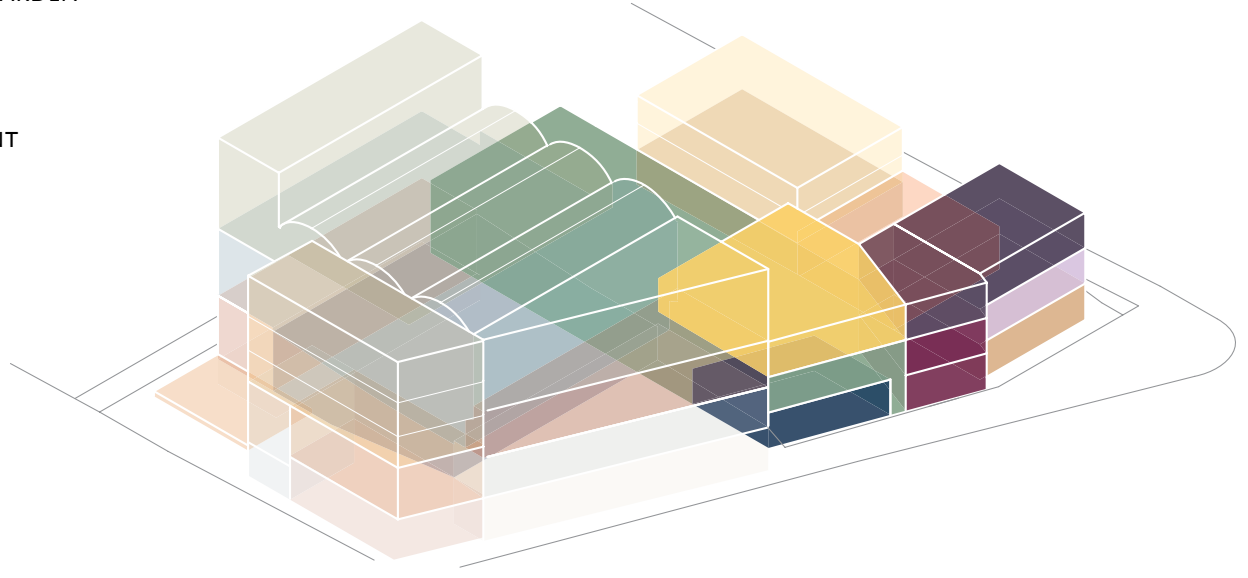

Fig. 4.5 Axo of Existing Brick Building

The Independent Cinema Room

The commercial space on the lower floor and immediately adjacent to the Empress is the one that struggled the most, due to its location. Therefore I propose to change its function as a new smaller cinema room. This new room would be reserved for repertoire projections, educational screening or special presentations followed by a discussion with the filmmaker, for example. The original entrance of the shop would be used as the emergency exit and a new entrance would be punctured in the east wall, connecting it to the main entrance hall of the Empress. Tickets could be bought at the main tickets box and cinephiles could then walk down to the smaller room, crossing through the thick wall of the theatre.

\section{The Shared Apartment}

Above the market entrance is a large shared apartment. It is ideal for individuals with lower incomes, willing to share amenities and costs, like students for example or artists wanting to rent semi-long-term while they do an art residency in the adjacent gallery. For this specific purpose, the apartment has an interior door that leads directly to the artist studio, connected to the gallery.

Instead of having a balcony, this apartment has a direct access to the community garden, which sits right above the market. 
The Bike Shop

At the center of the existing brick building, two spaces are reserved for shops, to provide income rent to the project. On the lower floor, is a bike shop that is already in place. With the new pedestrian lane at the back of the building, customers can now easily roll their bikes down to the shop for repairs.

The other shop, right above the bike shop is just a simple open space to welcome any kind of small business.

The Daycare

Next to the bike shop, also on the lower floor is the daycare. A ramp has been added to the west side of that space to provide easier access for parents with strollers. Two large windows have also been punched through the existing exterior wall to bring in more daylight. When entering the daycare, a large mezzanine invites parents to come in, sit and chat while waiting for their children to get ready to leave.

The back of the daycare is open and connected to the community kitchen. This is to allow children to see what is going on in there and pique curiosity. On certain days the children could even have cooking classes. Furthermore, retired volunteers could be in charge of making the meals for the children which could eat at the dinning table, facing the pedestrian lane.

The Galleryl Artist Studio/ Restaurant Above the daycare is a restaurant. The restaurant is also connected to the gallery that sits above it. A large opening in the floor/ceiling creates a visual connection and attracts the interest of the people dinning in the restaurant. People are invited to circulated between the two levels. These two pieces of the program have been combined to offer an increased use of the terrasse that sits at the back, above the community kitchen. 


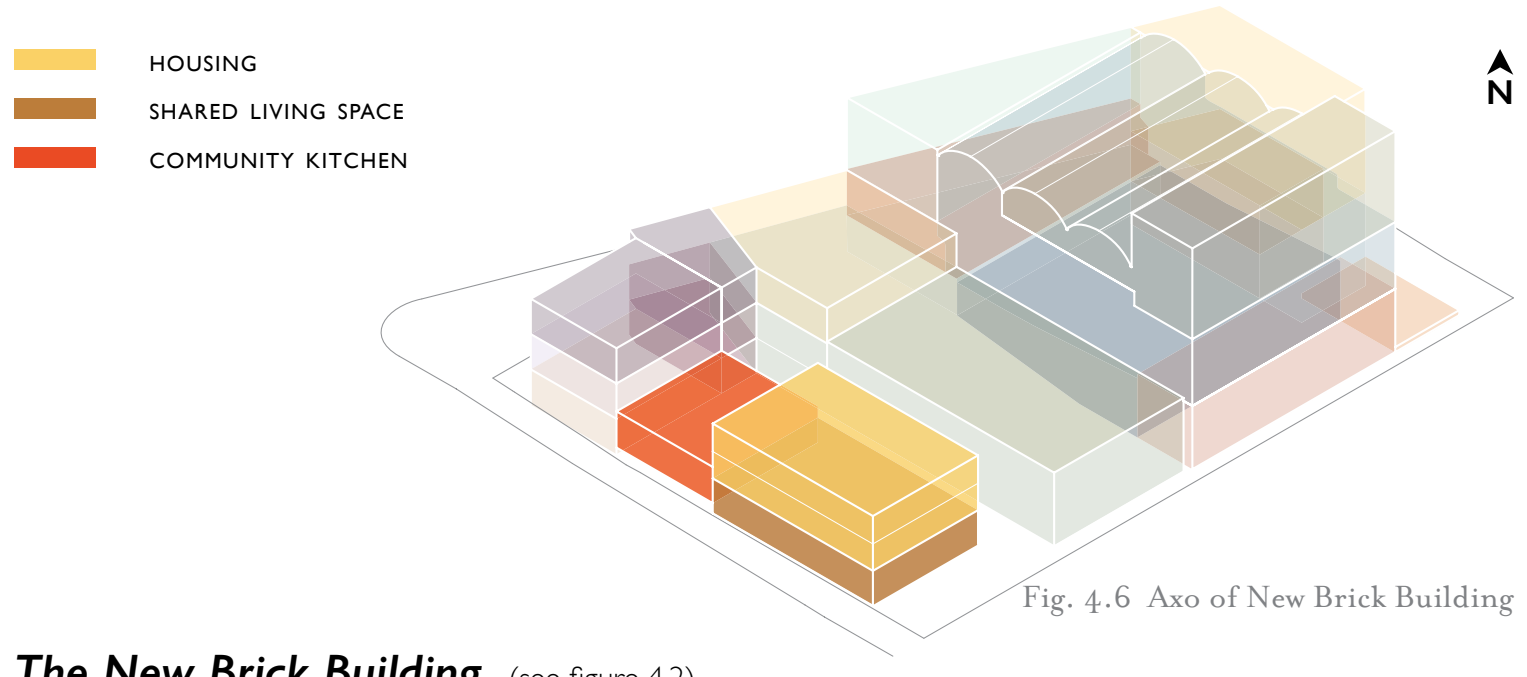

\section{The New Brick Building (see figure 4.2)}

The Community Kitchen

Behind the daycare stands the community kitchen. That space has direct access from Marcil street and in the summertime can open to the pedestrian lane. From the inside it is connected to the daycare and to the communal dining, below the studio housings. The kitchen is open to the public but users must simply reserve a time-slot. A few hours are also reserved to prepare the meals for the children of the daycare.

The Apartment Studios

On Marcil street a completely new building has been added to the project. This building contains 8 studio apartments, laid out on two floors above ground. These along with other apartments in the project are to respond to the affordable housing crisis currently talking place in Montreal. These studios could welcome single people or couples, with lower incomes and in need of community support. The eight apartments are accessed by two entrances and staircases. Four tenants share the same entrance to encourage the development of closer relationships between neighbours. The studios are small although they still offer a good quality of life to their occupants. To compensate, on the ground floor there is a large communal room that offers the residents more shared living area.

\section{The Communal Space - Dinning Room/ Living Room/ Recreation Room}

The communal space at the ground floor covers the whole footprint of this new building. It is divided by the two staircases into three different spaces; the dinning room, connected to the community kitchen, the living room, opening to the back lane and the recreation room, where residents can be a little more lively around a ping pong match for example. Below both staircases, lockers have been designed to provide more storage space for each tenant. This communal space is meant to offer more space to these residents but more so to encourage encounters and social interaction, to help develop a stronger community. 


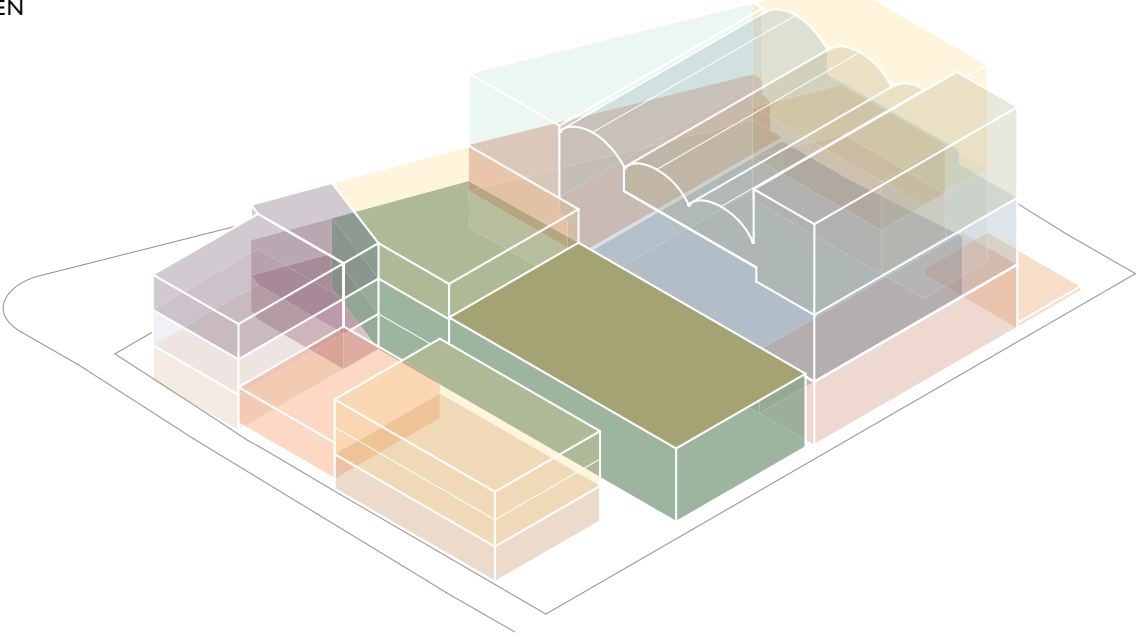

Fig. 4.7 Axo of Market

The Market

The main entrance to the market is at the lower level on Sherbrooke street, between the small projection room and the bike shop. This entrance first goes through a widening corridor, along the back of the screen in the projection room, which is partially visible. It then leads to the double height market space. The market is organized around a grid of large concrete columns that are surmounted by thick concrete domes.

Large glass doors on the west side of the room can be opened in the summer to extend the space to the pedestrian lane. The space is designed to host daily markets but can also be reserved for celebrations of all kinds. The grandeur of this space is meant to celebrate the fact that markets are one of the things that every single culture in the word shares.

Above the small screening room is a smaller space reserved for administration work for the volunteers and staff of the market and the whole complex. This space was chosen for its nice daylight and easy access to all the facilities in particular the market. It is also visible fromthe street, which is favorable for people to find and access if they have any questions or inquiries about the facilities.

In The Practice of Everyday Life, De Certeau said "The market is traditionally an important sociological landmark for the understanding of human relations within the practice of the neighbourhood. No city or village is without one. At the same time it is a place of business, it is a place of festival (...)" ${ }^{29}$. For me the market is where you see the true local culture without any artifice. Yet for a foreigner, it can look like a theatrical performance and it can be quite entertaining. 


\section{The Community Garden}

The community garden, being behind the existing brick building is not visible from Sherbrooke street although the door, all the way to the east side of the front façade, leads directly to the garden. This staircase also offers quick access to the green roof top for the staff working in the administrative space of the market. A larger and more obvious staircase on Marcil street, on the west side, also leads to the garden.

The lots in the garden have to be reserved by residents of the neighbourhood but the garden is still accessible to the greater public. The garden aims to provide residents who do not have a backyard, a small lot where they can grow vegetables giving them better access to fresh produce. At the same time, this community garden will provide a nice opportunity for neighbourhood activities and exchange. Thus, in the summertime, all are invited to watch outdoor projections on the large wall of the Empress while sitting between the fresh vegetables.

In Liverpool, psychotherapist Margaret Ruegg ran a refugee support centre as part of her research on helping immigrants adapt to their new homes. Her research was based on the idea that gardening is highly beneficial physically and mentally for newcomers who have suffered different traumas. Therefore, she gave them a little plot of land to grow their ownvegetables. She discovered that not only did the community garden allow the refugees to produce a bit of food, but most importantly, it gave them a purpose and allowed them to build connections with their neighbours without having to be overly prescriptive about it. ${ }^{28}$ 


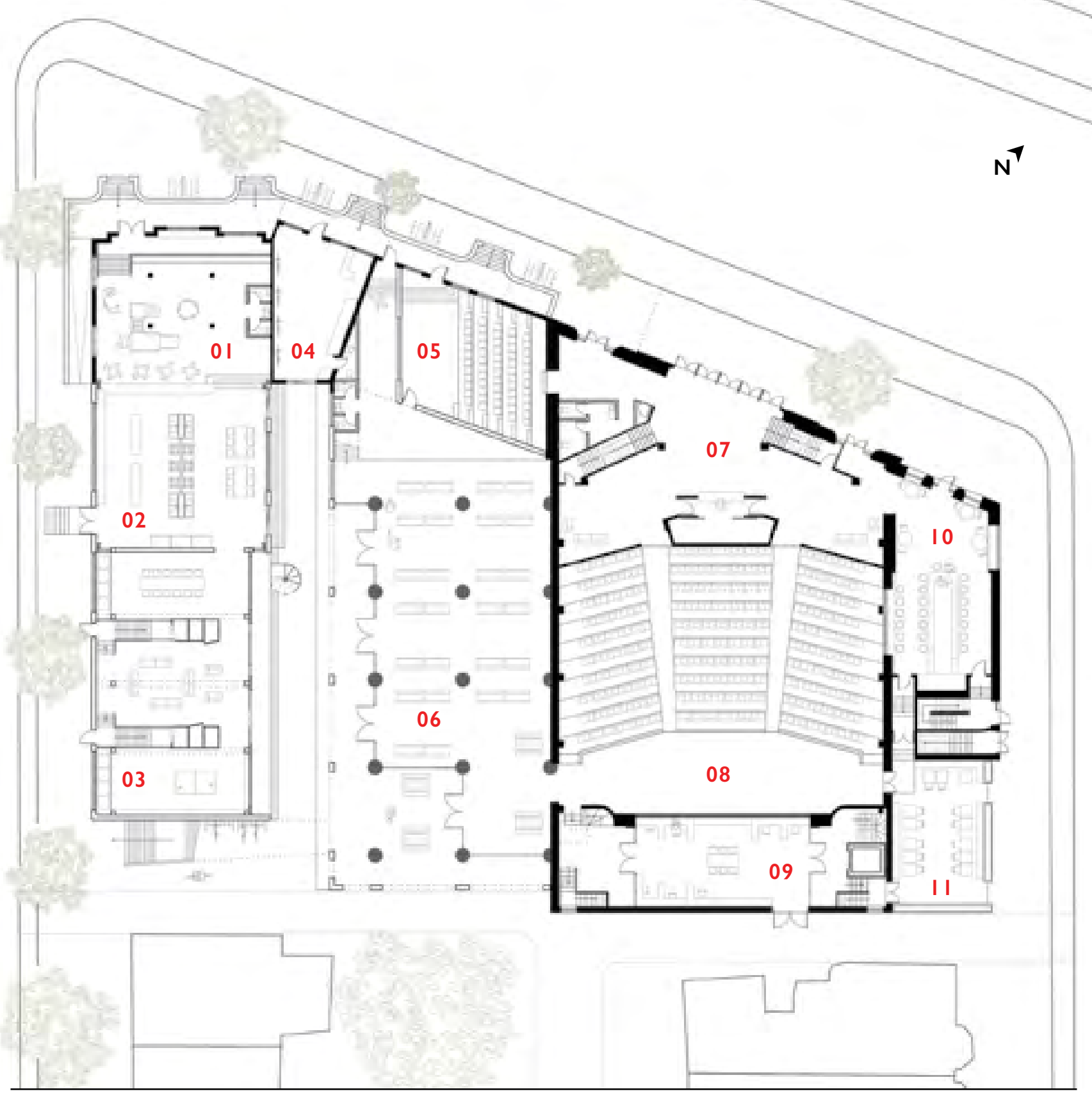

Ground Floor Plan

$\begin{array}{ll}01 & \text { DAYCARE } \\ 02 & \text { COMMUNITY KITCHEN } \\ 03 & \text { SHARED LIVING SPACE } \\ 04 & \text { BIKE SHOP } \\ 05 & \text { INDEPENDANT CINEMA } \\ 06 & \text { MARKET }\end{array}$

07 ENTRANCE HALL

08 MOVIE THEATRE

09 PRODUCTION ROOM

I0 BAR

II TERRASSE

Fig. 4.8 Ground Floor Plan 


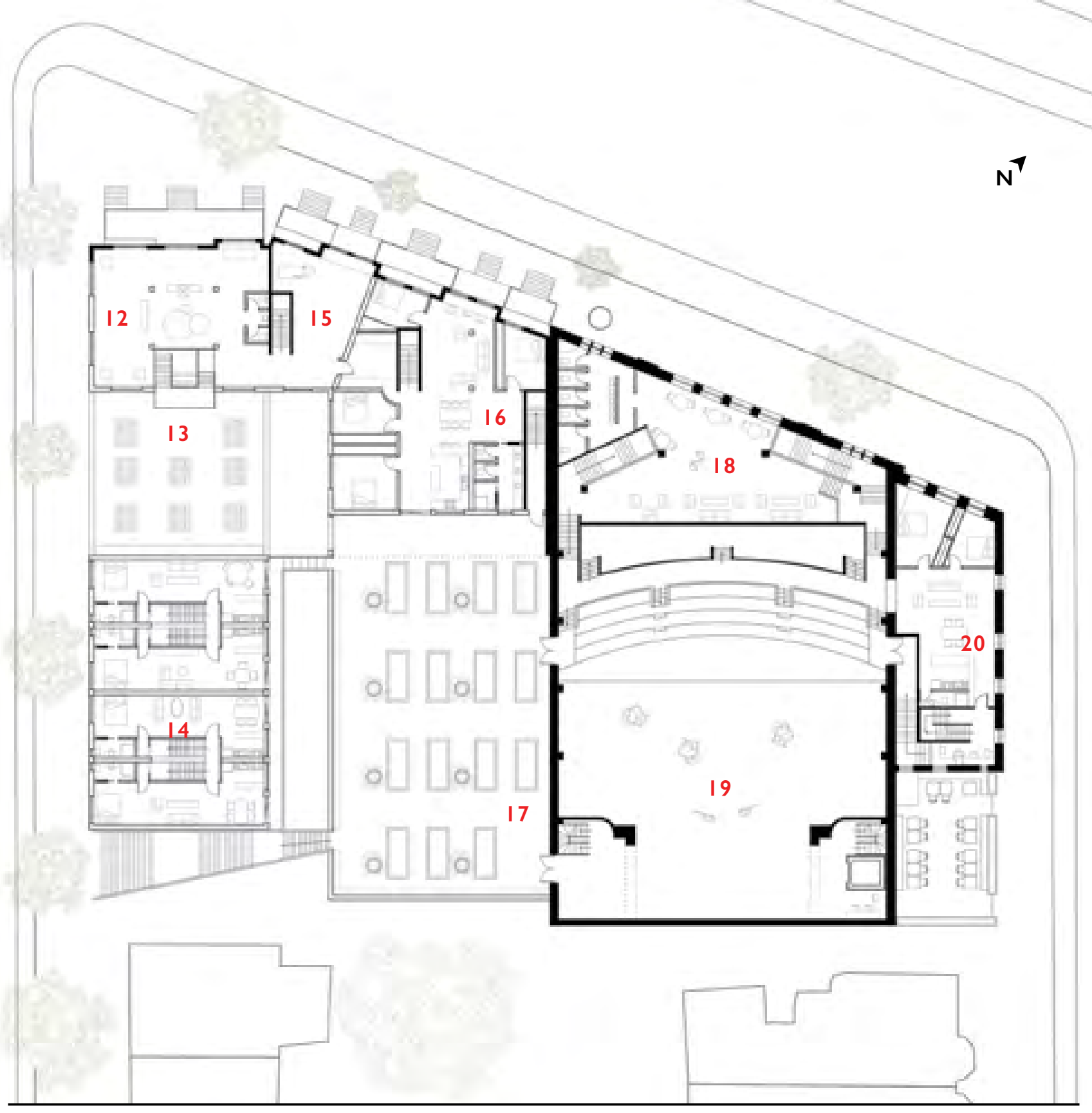

\section{Second Floor Plan}

$\begin{array}{ll}\text { I } 2 & \text { GALLERY } \\ \text { I } 3 & \text { TERRASSE } \\ \text { I } 4 & \text { STUDIO APARTMENTS } \\ \text { I5 } & \text { ARTISTS STUDIO } \\ \text { I6 } & \text { SHARED APARTMENT }\end{array}$

$\begin{array}{ll}\text { I7 } & \text { COMMUNITY GARDEN } \\ \text { I8 } & \text { CO-WORKING/ FOYER } \\ 19 & \text { MAIN THEATRE HALL } \\ 20 & \text { APARTMENT }\end{array}$




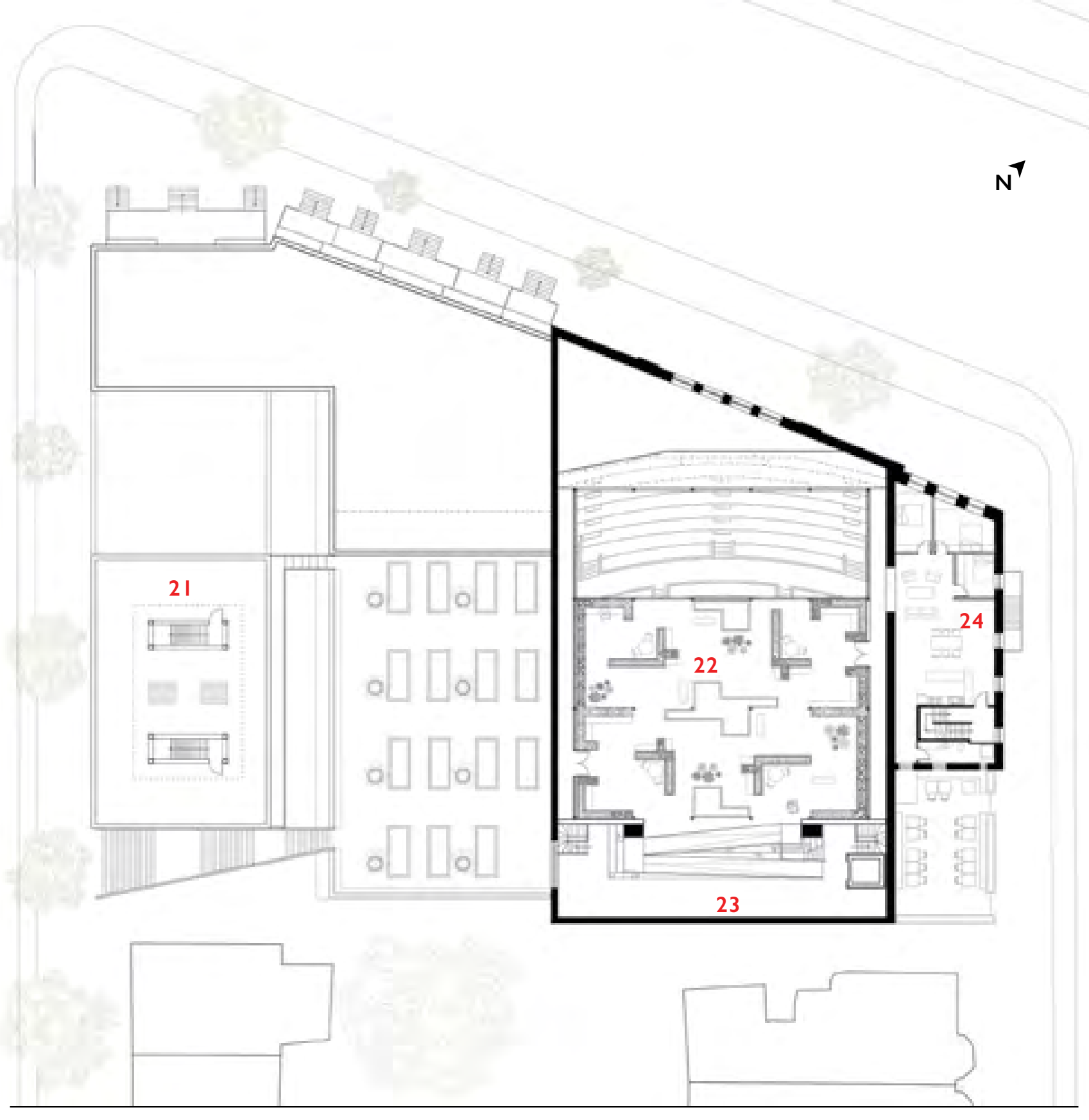

\section{Second Floor Plan}

2 I APARTMENTS SHARED ROOFTOP

22 INDOOR GARDEN
23 STORAGE \& POTING SPACE

24 APARTMENT 

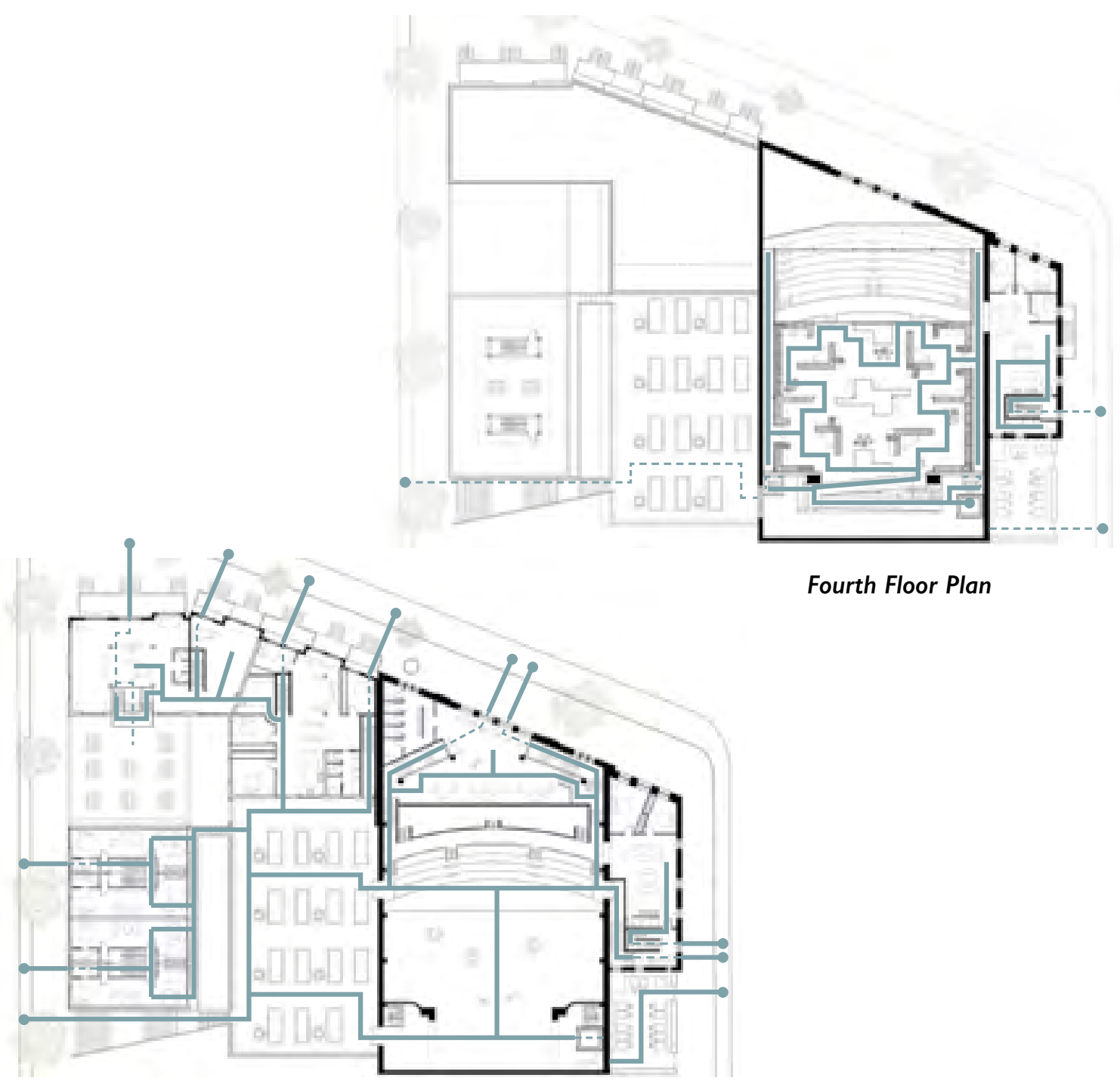

Fourth Floor Plan

Second Floor Plan

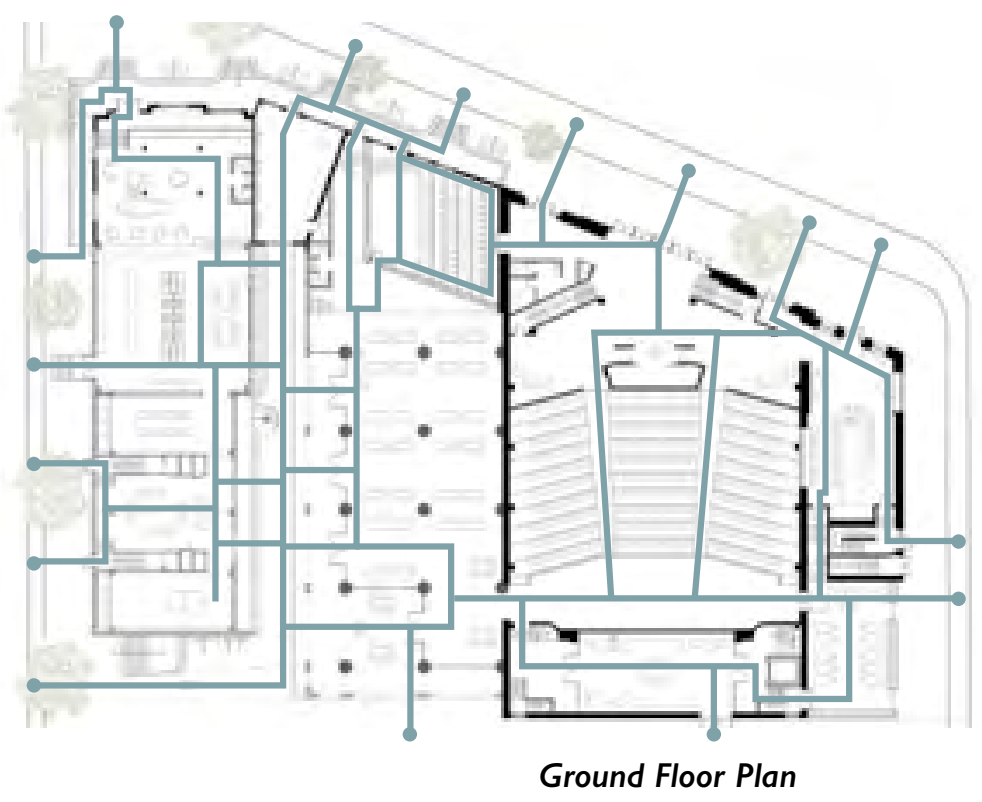

Circulation and Access Points

Fig. 4.II Circulation 


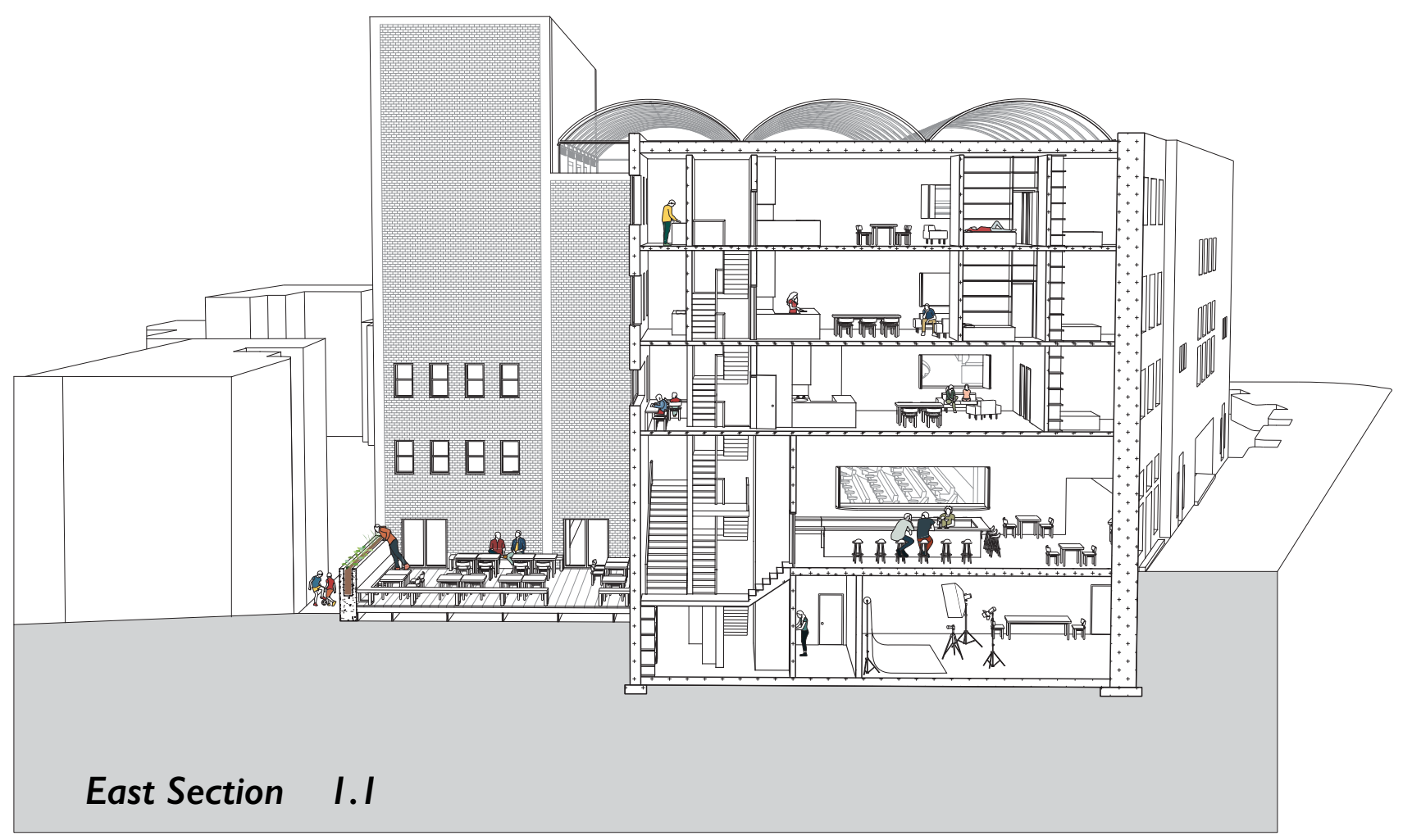

Fig. 4.I2 East Section Out

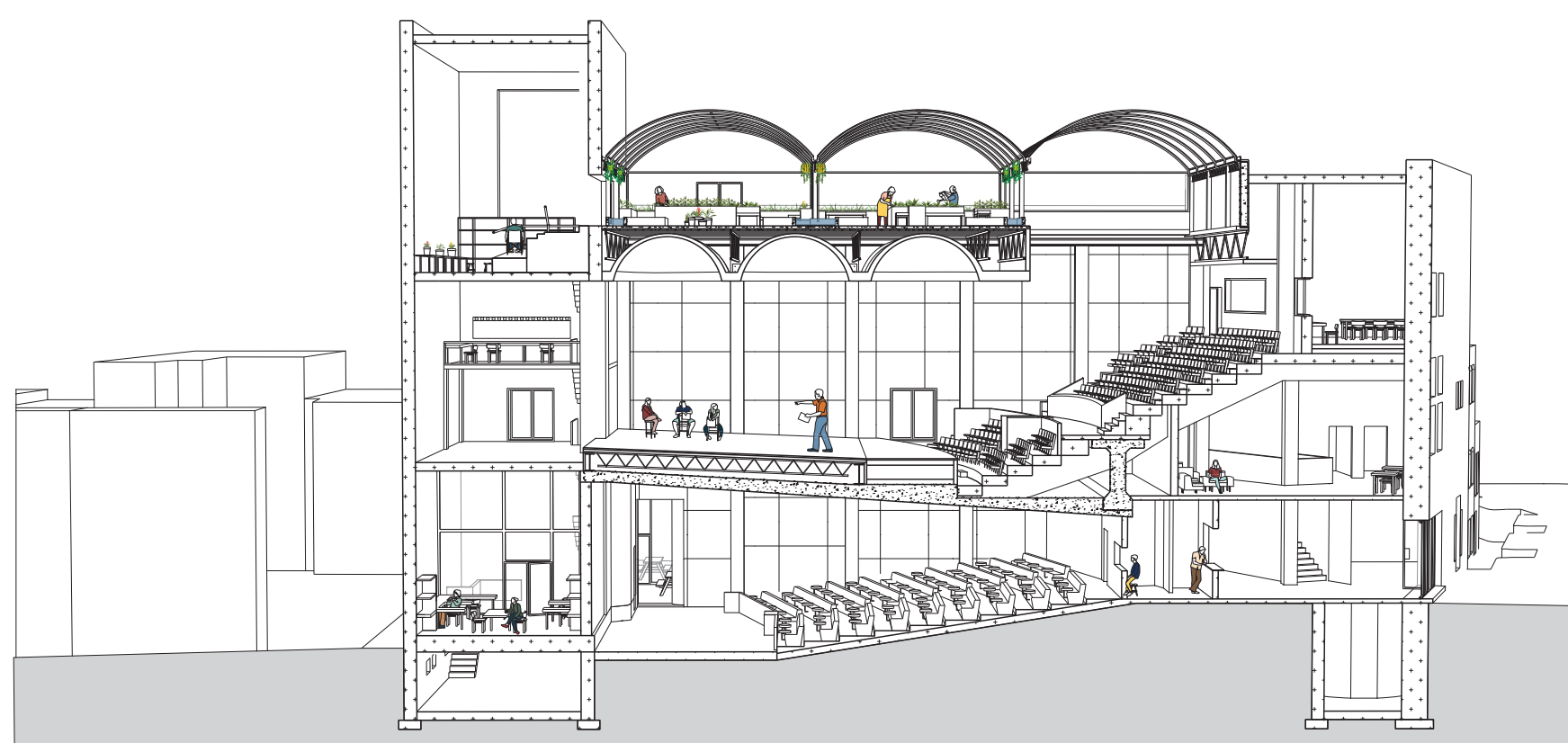

East Section $\quad I .2$

Fig. 4.I3 East Section In 

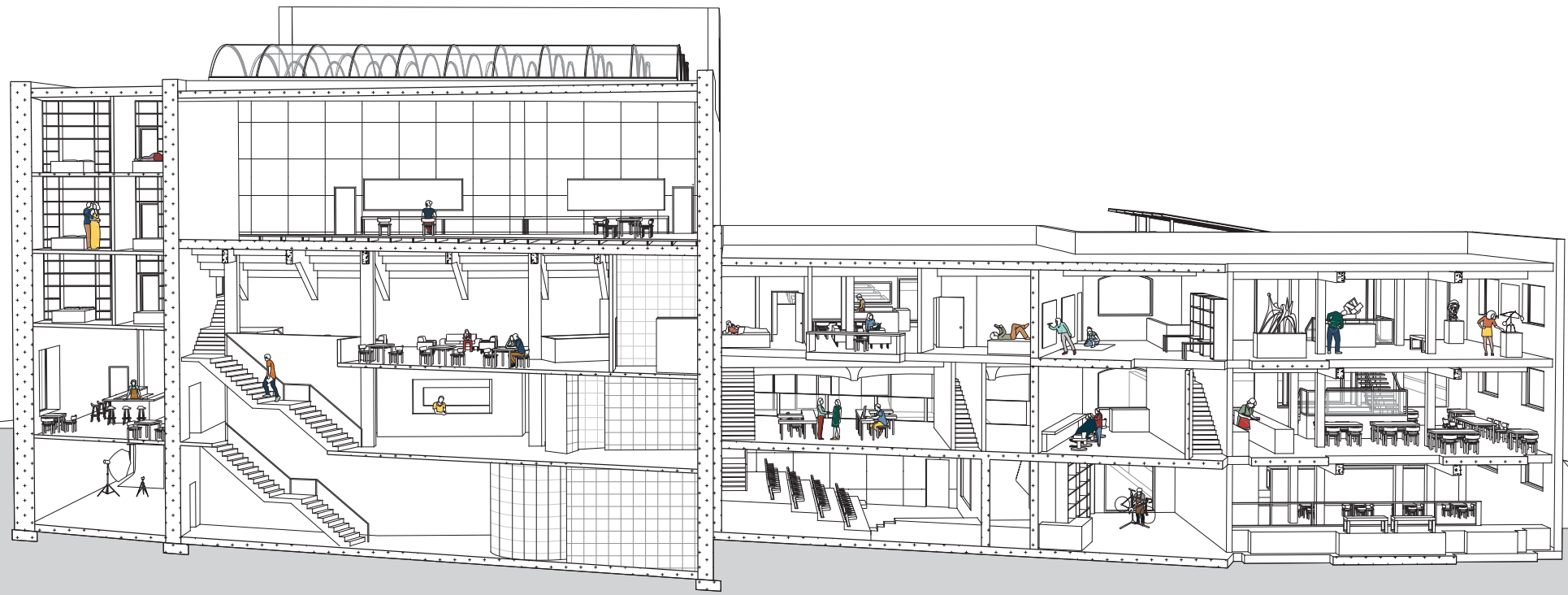

North Section 2.I

Fig. 4.I4 North Section Out 


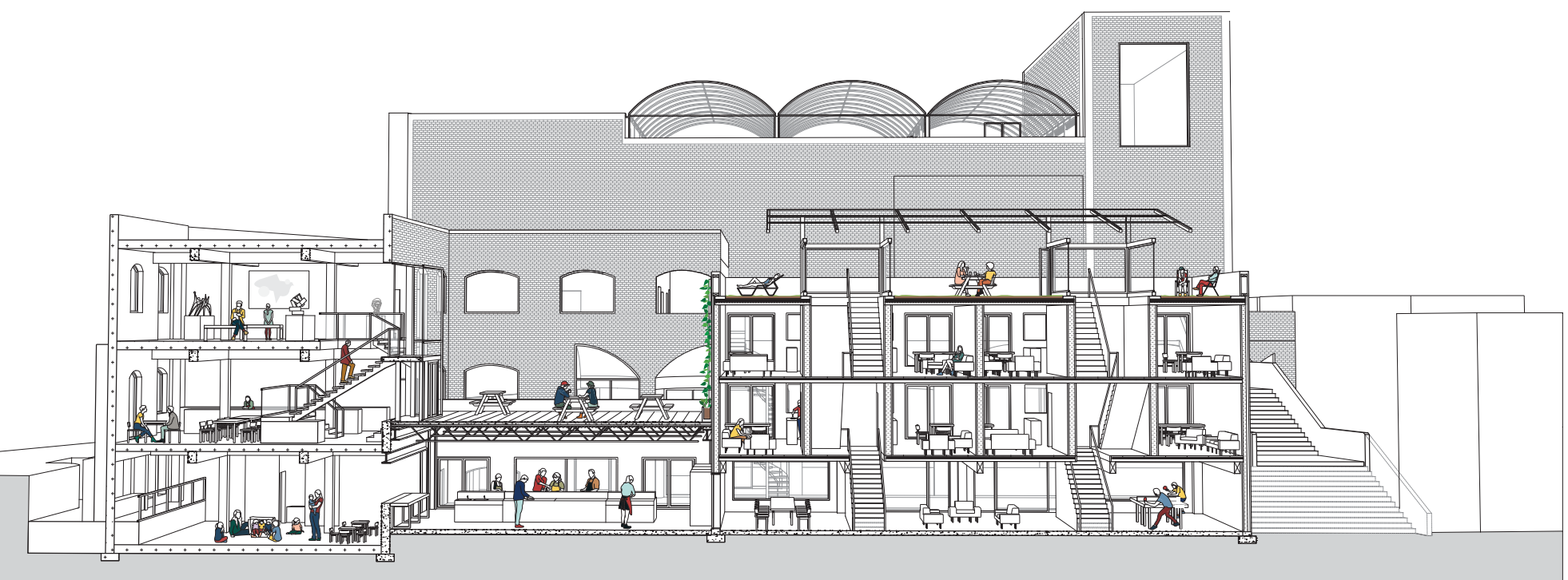

West Section 3.1

Fig. 4.I5 West Section Out

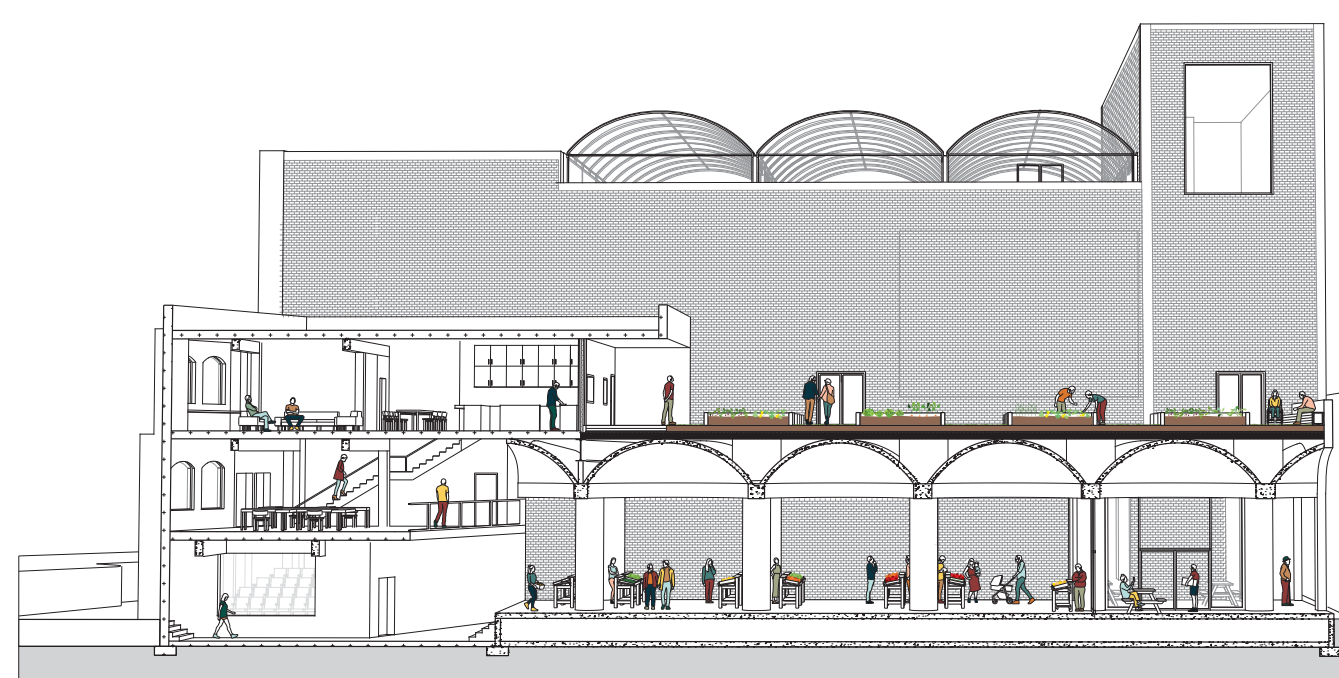

West Section 3.2

Fig. 4.I6 West Section In 


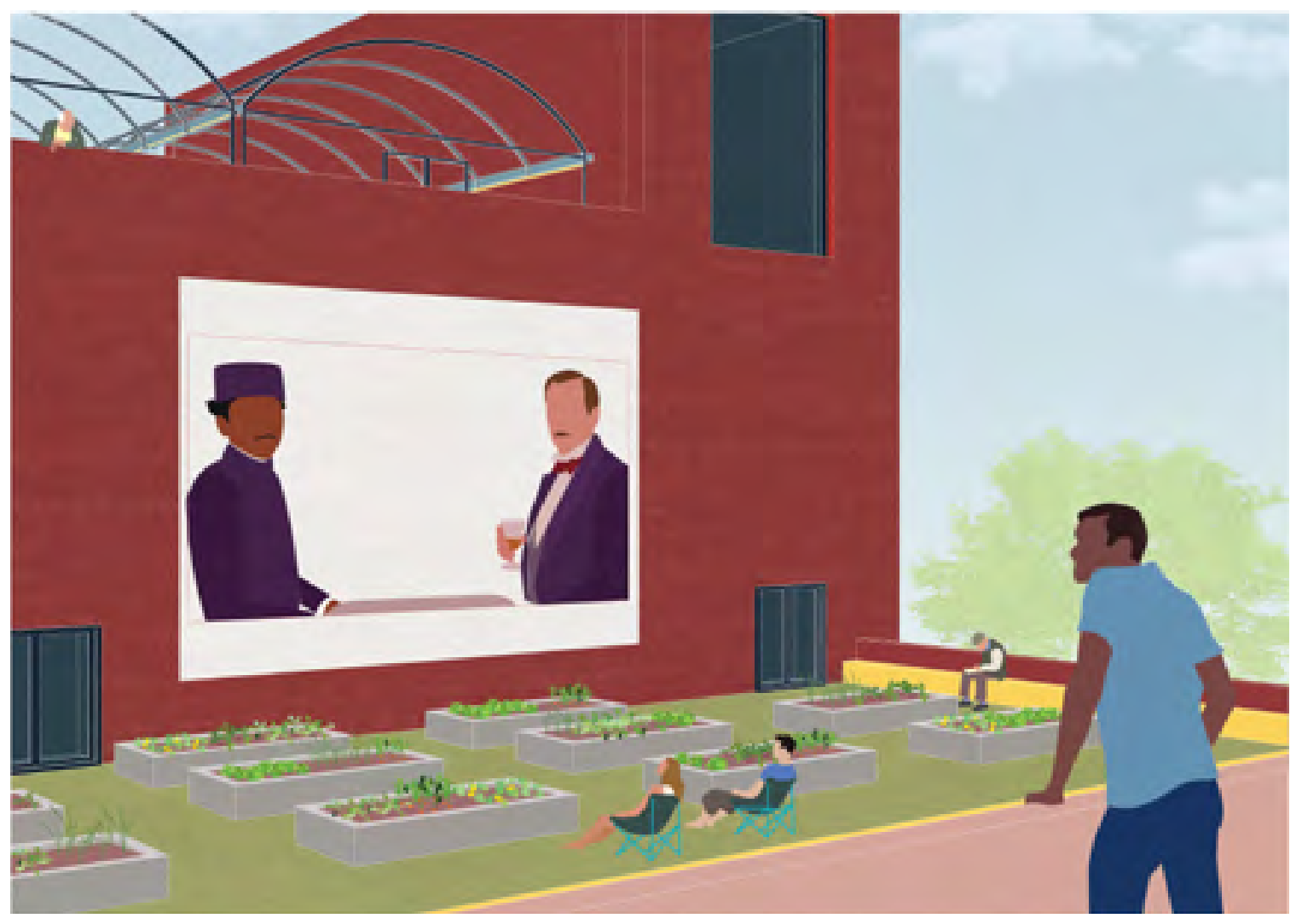

Fig. 4.I7 Linger

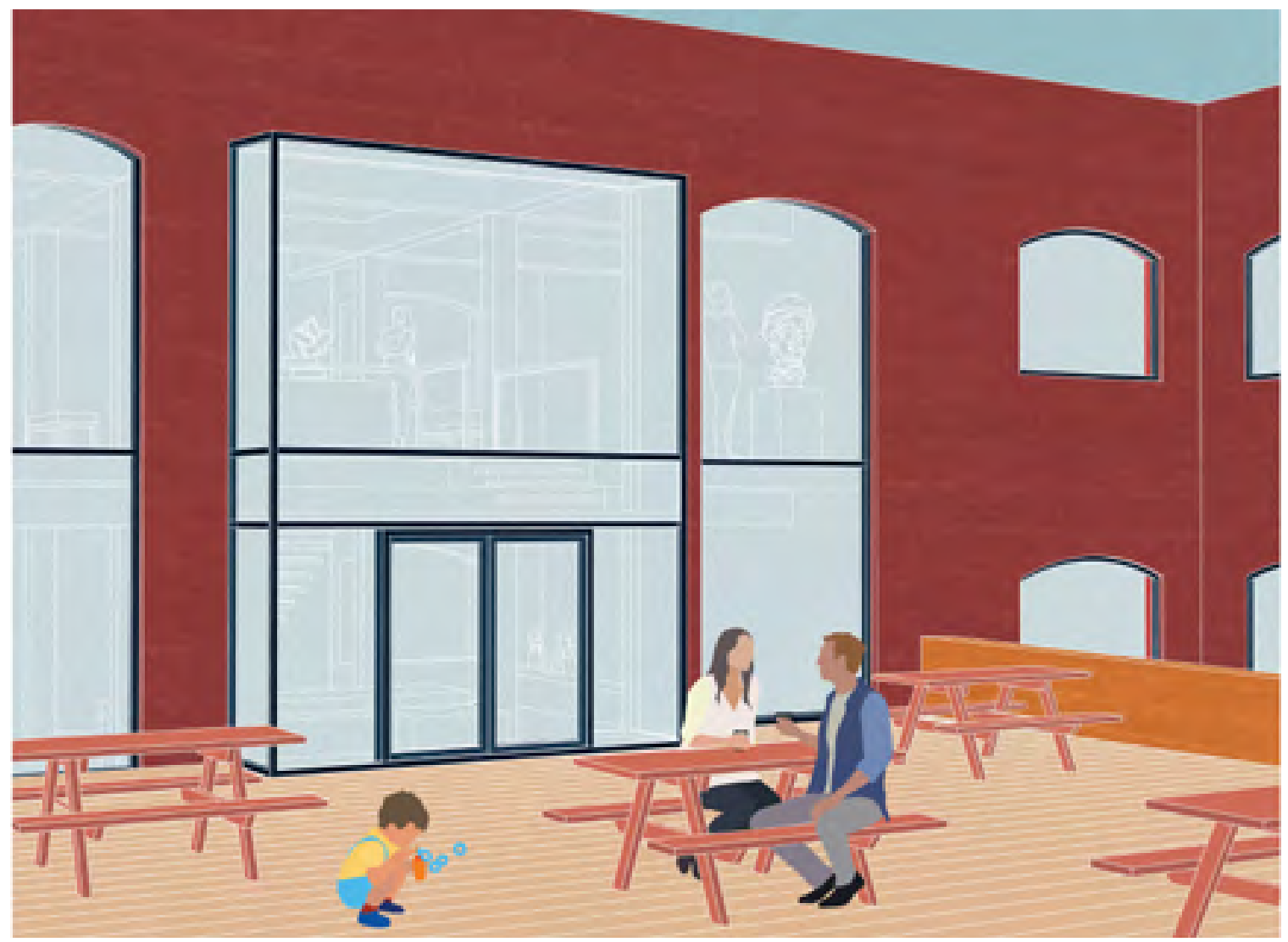

Fig. 4.I8 $3^{\text {rd }}$ Spaces 

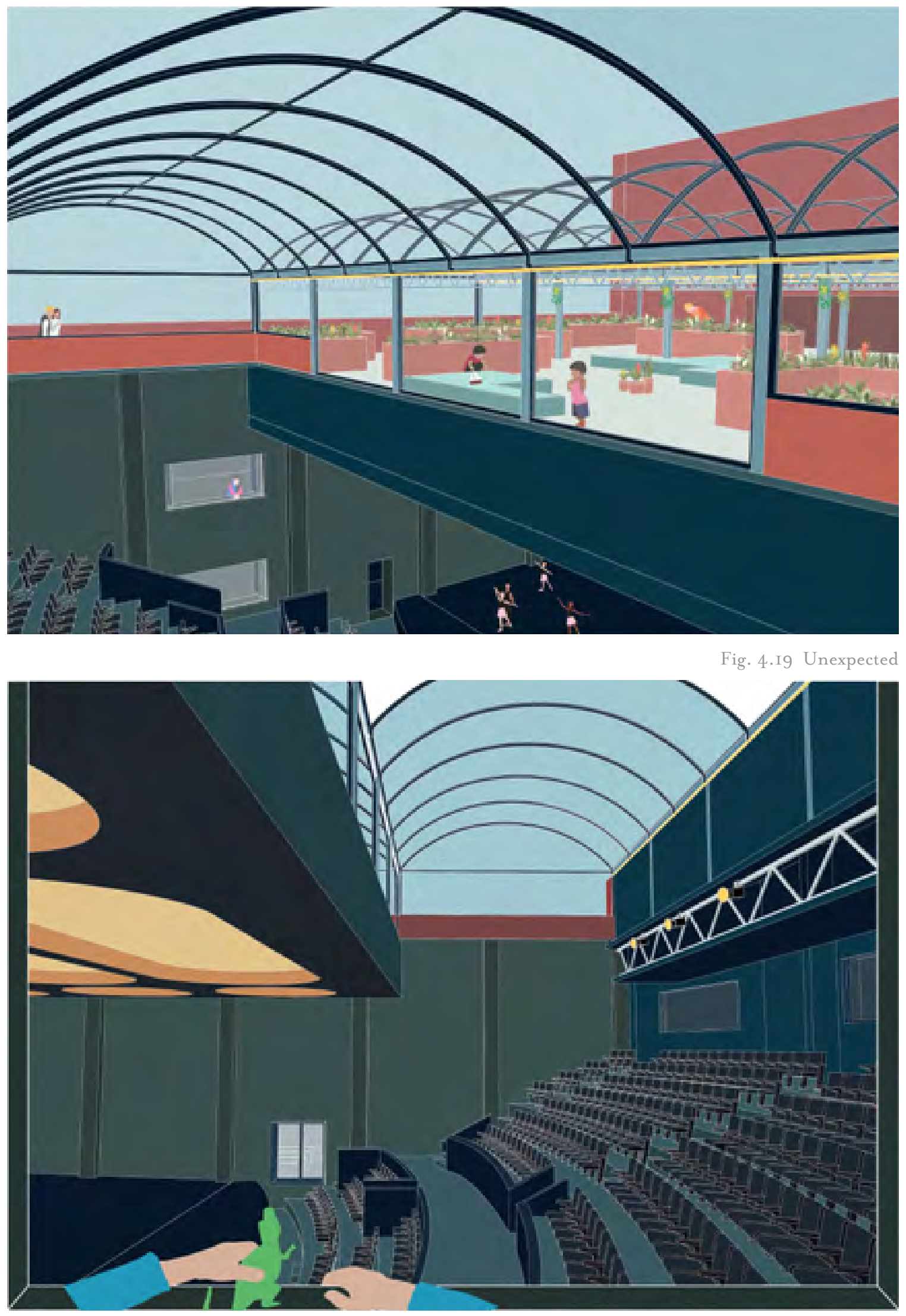

Fig. 4.20 Unexpected 


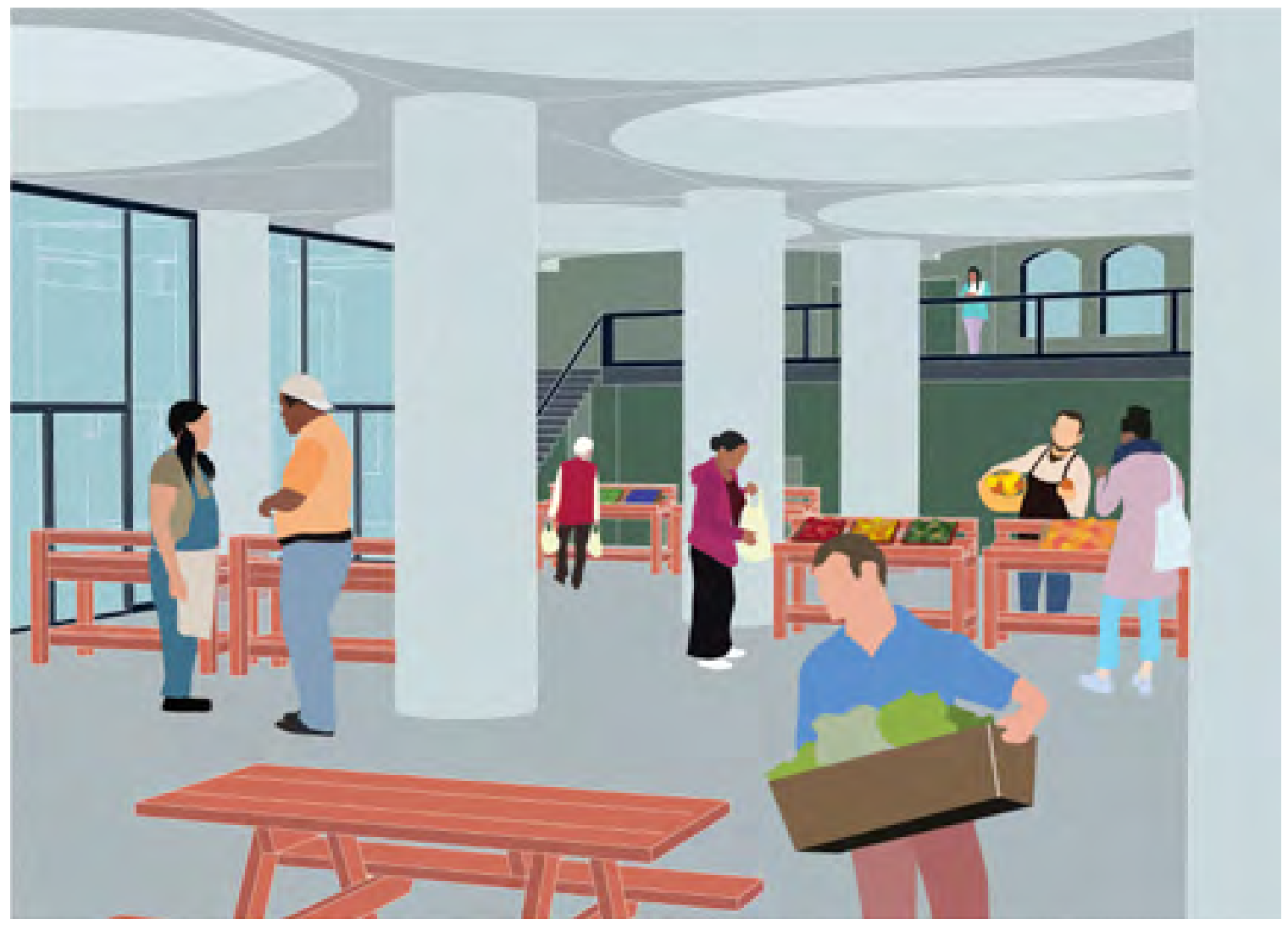

Fig. 4.2I Flexible

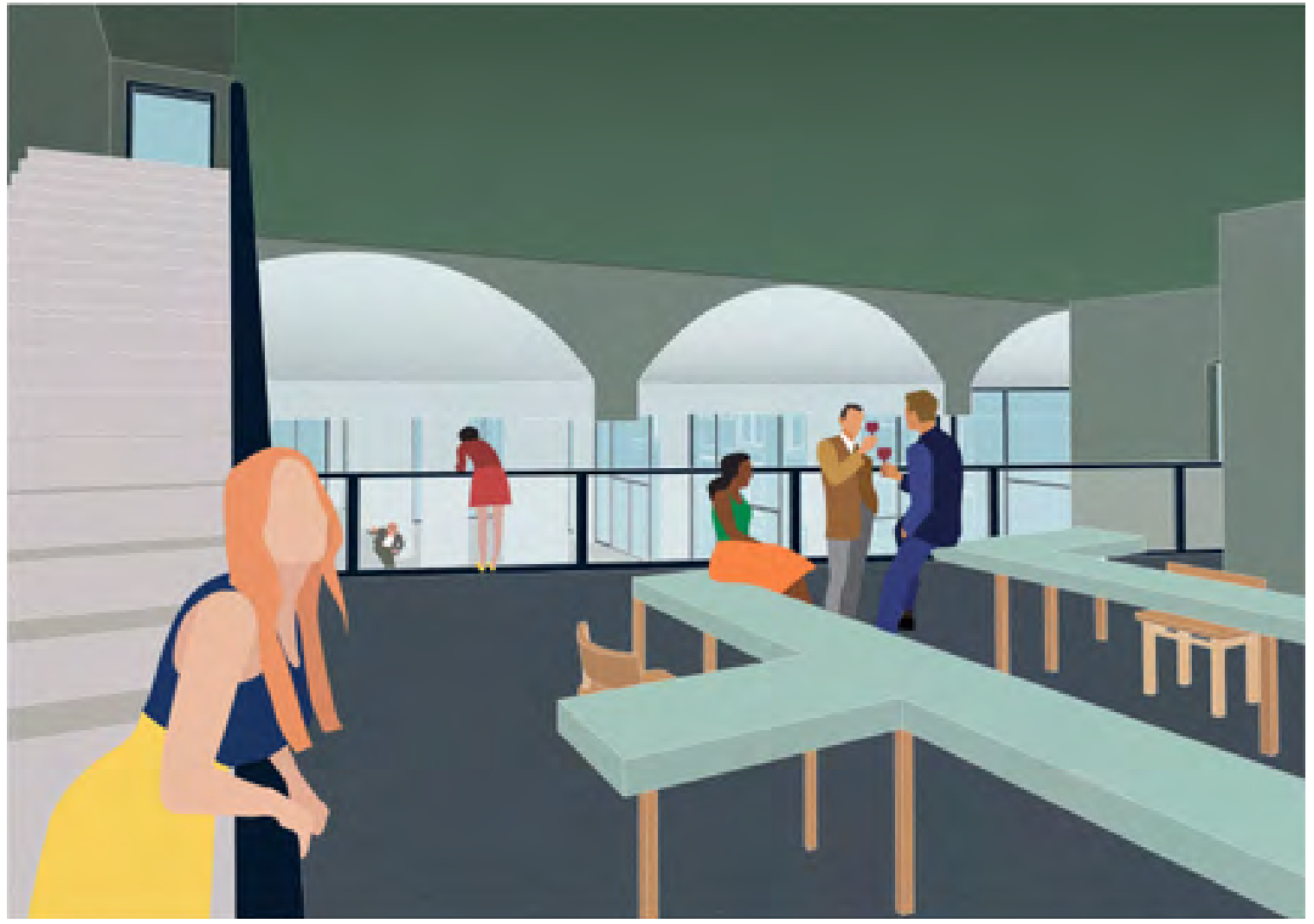

Fig. 4.22 Flexible 


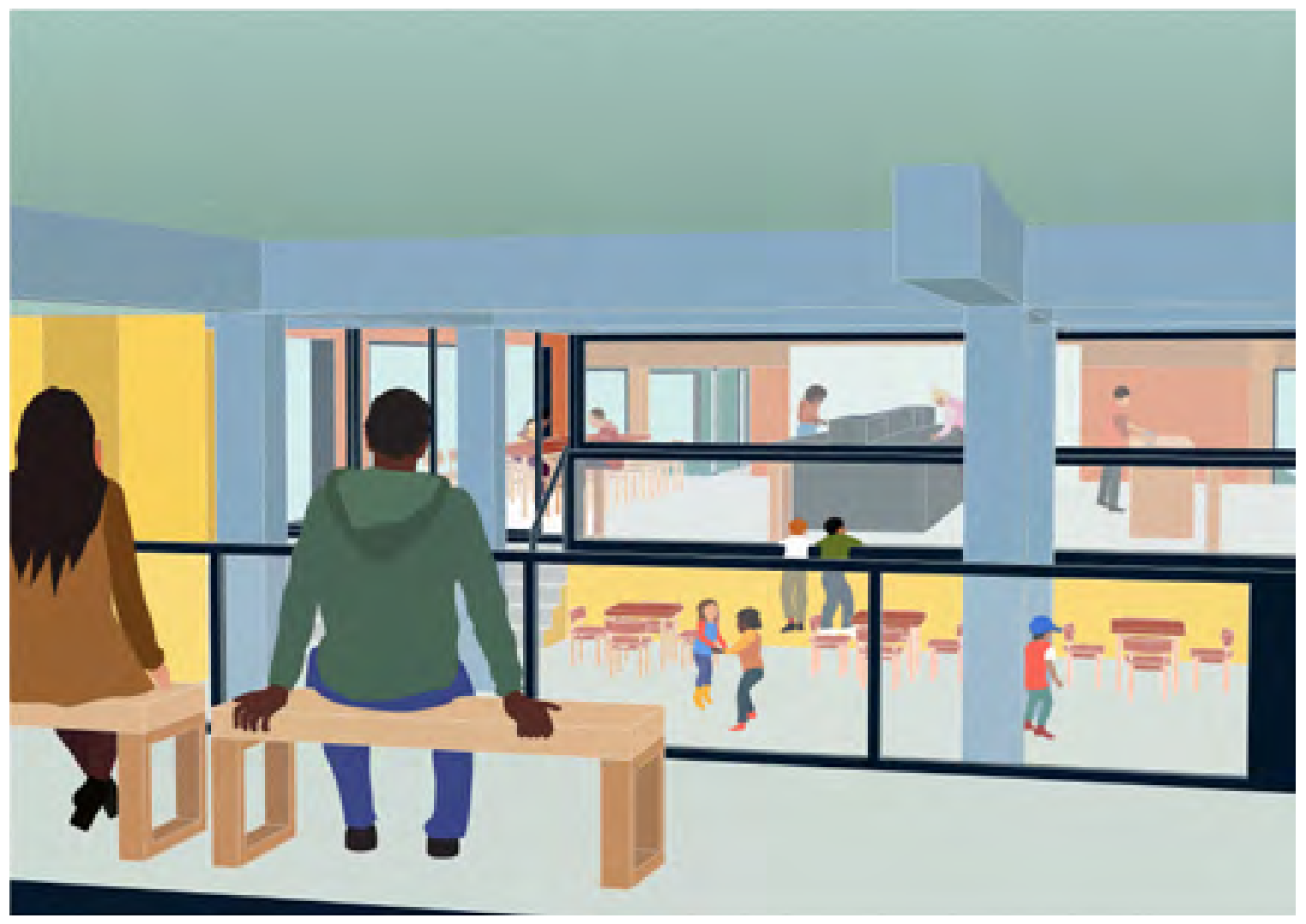

Fig. 4.23 Juxtaposition

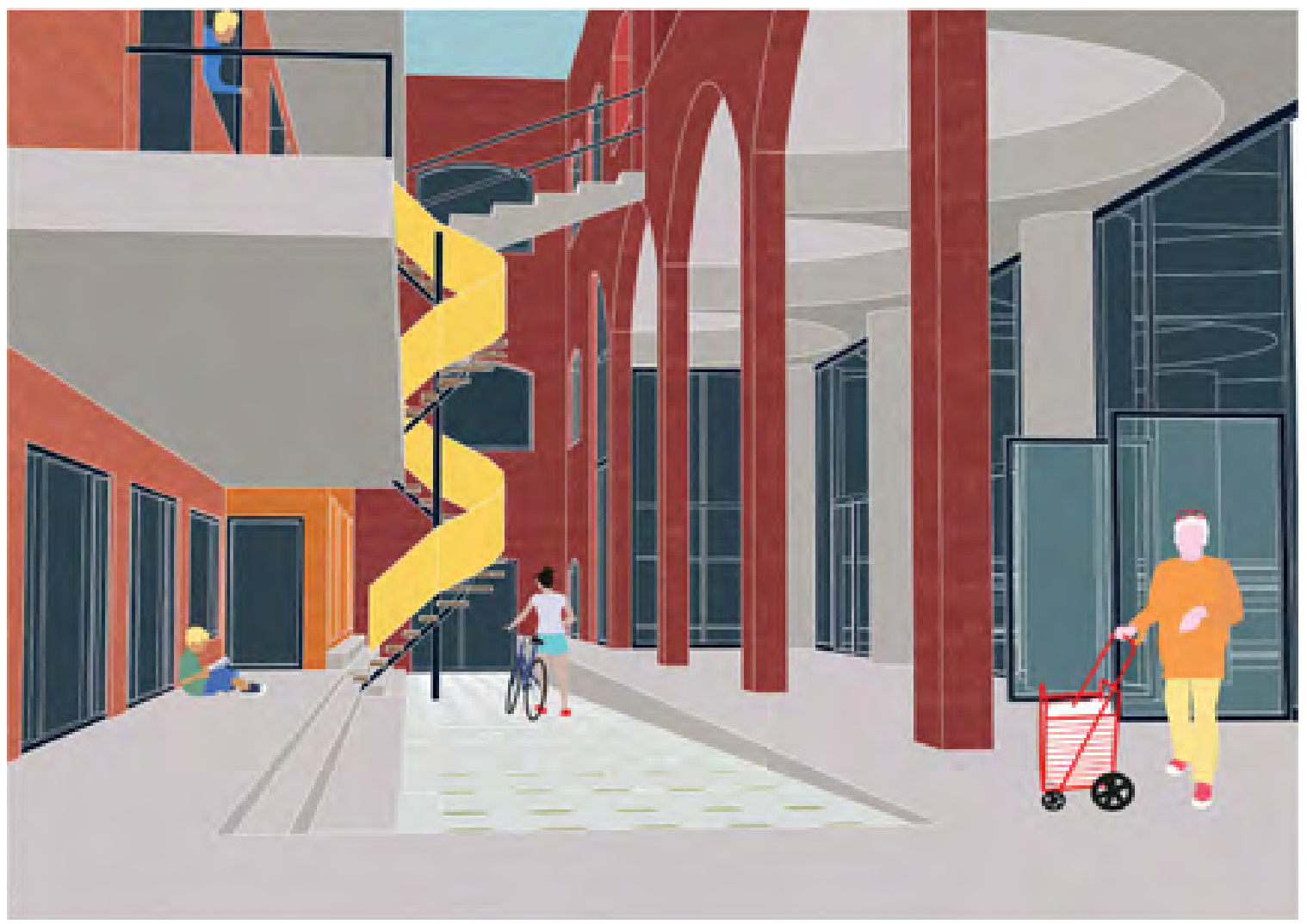

Fig. 4.24 Juxtaposition 


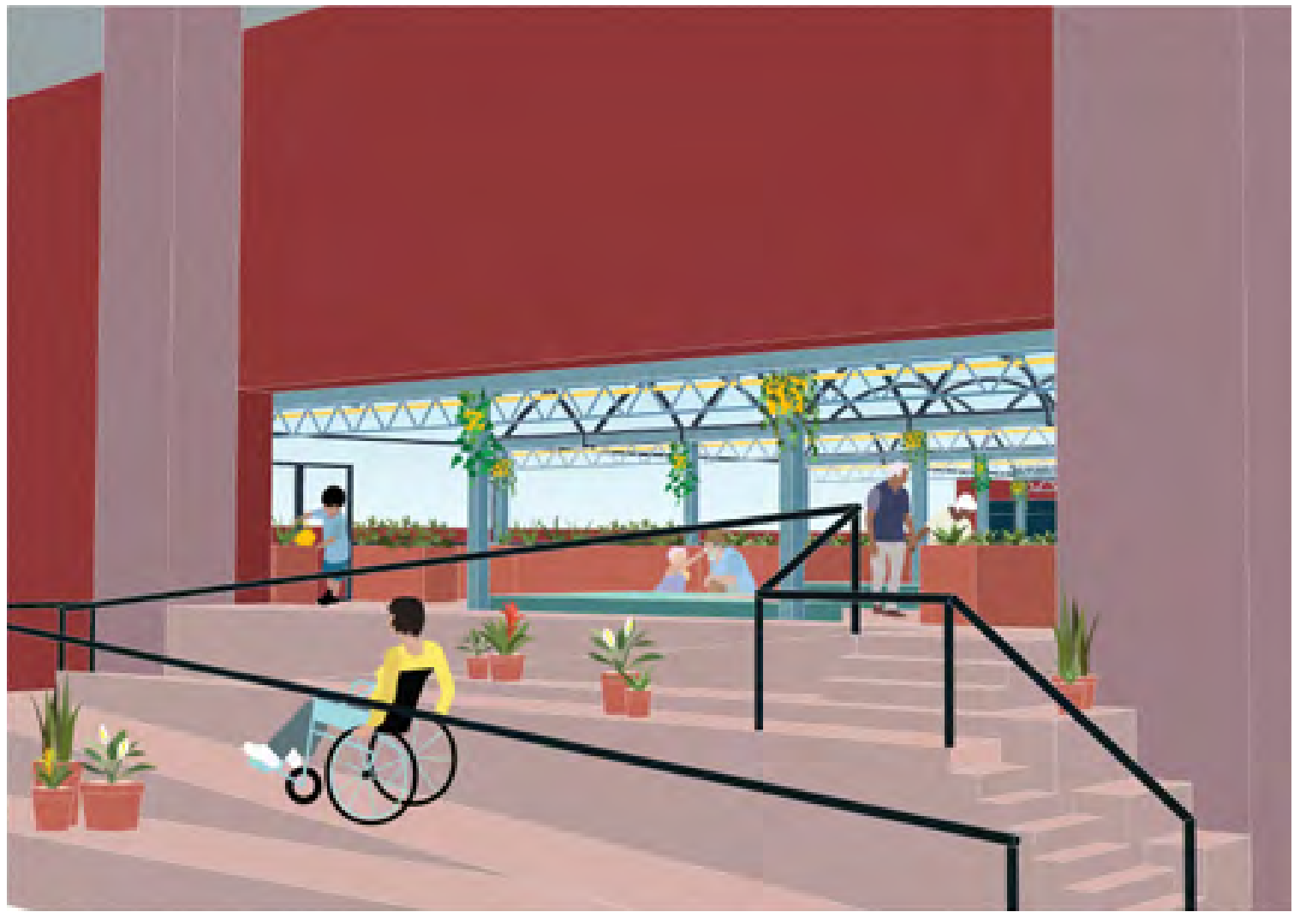

Fig. 4.25 Inclusive 
28. Michel DeCerteau. The Practice of Everyday life

29. The Guardian. Margaret Ruegg

https://www.theguardian.com/film/filmblog/2007/may/I 0/cultivatinggrowyourown 


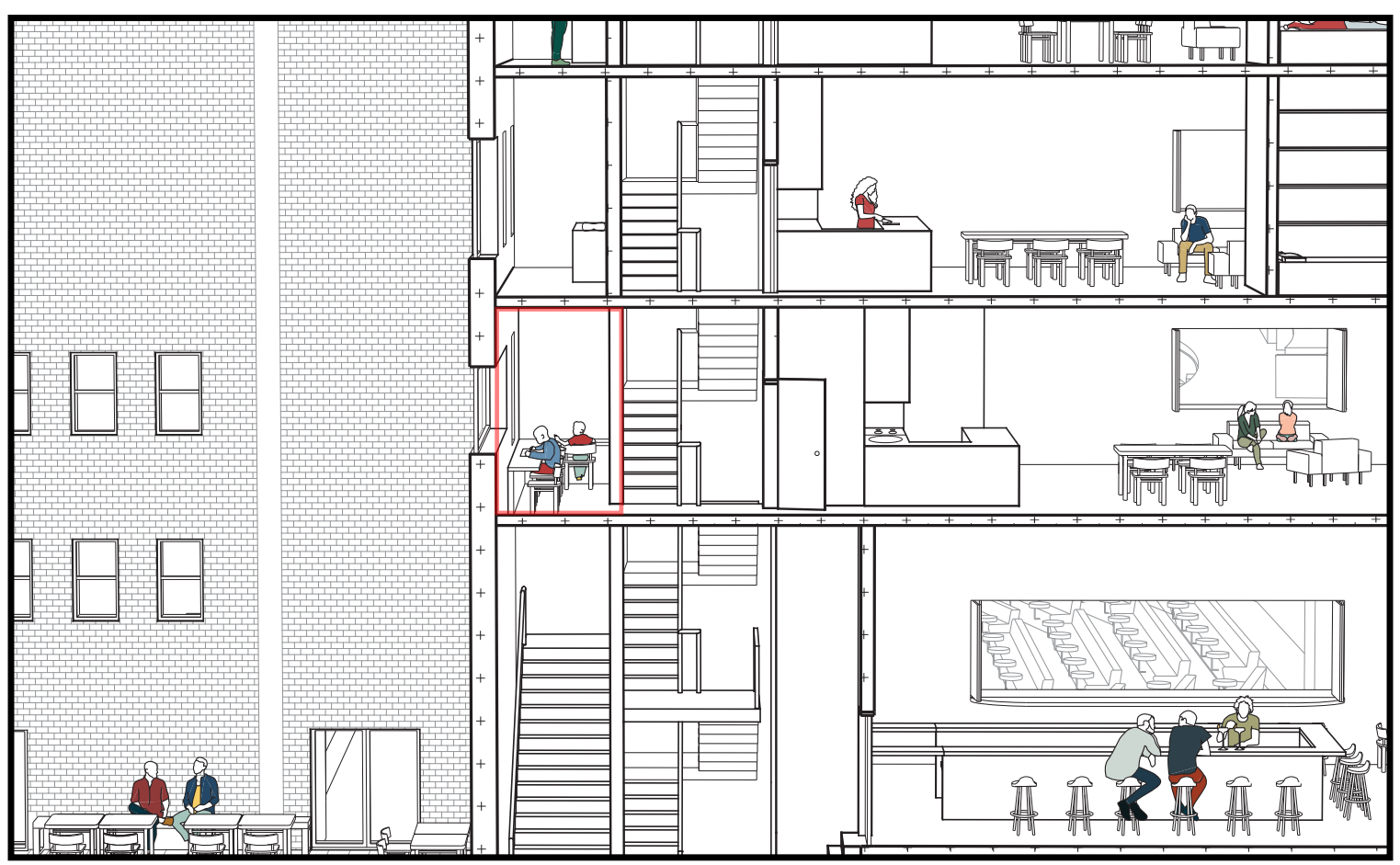

Fig. 5.2 Abdou

Abdou is 12. He lives with his mom and dad in one of the apartments in the annex of the Empress. Luckily for him, Simon, also I 2, lives in the apartment right below, with his mom. Everyday after class, they do their homework together in the shared office space on the second floor. When they're done, they usually go play soccer in the alley, behind the Theatre. That's where they met Greg who sometimes plays with them as a goalkeeper.

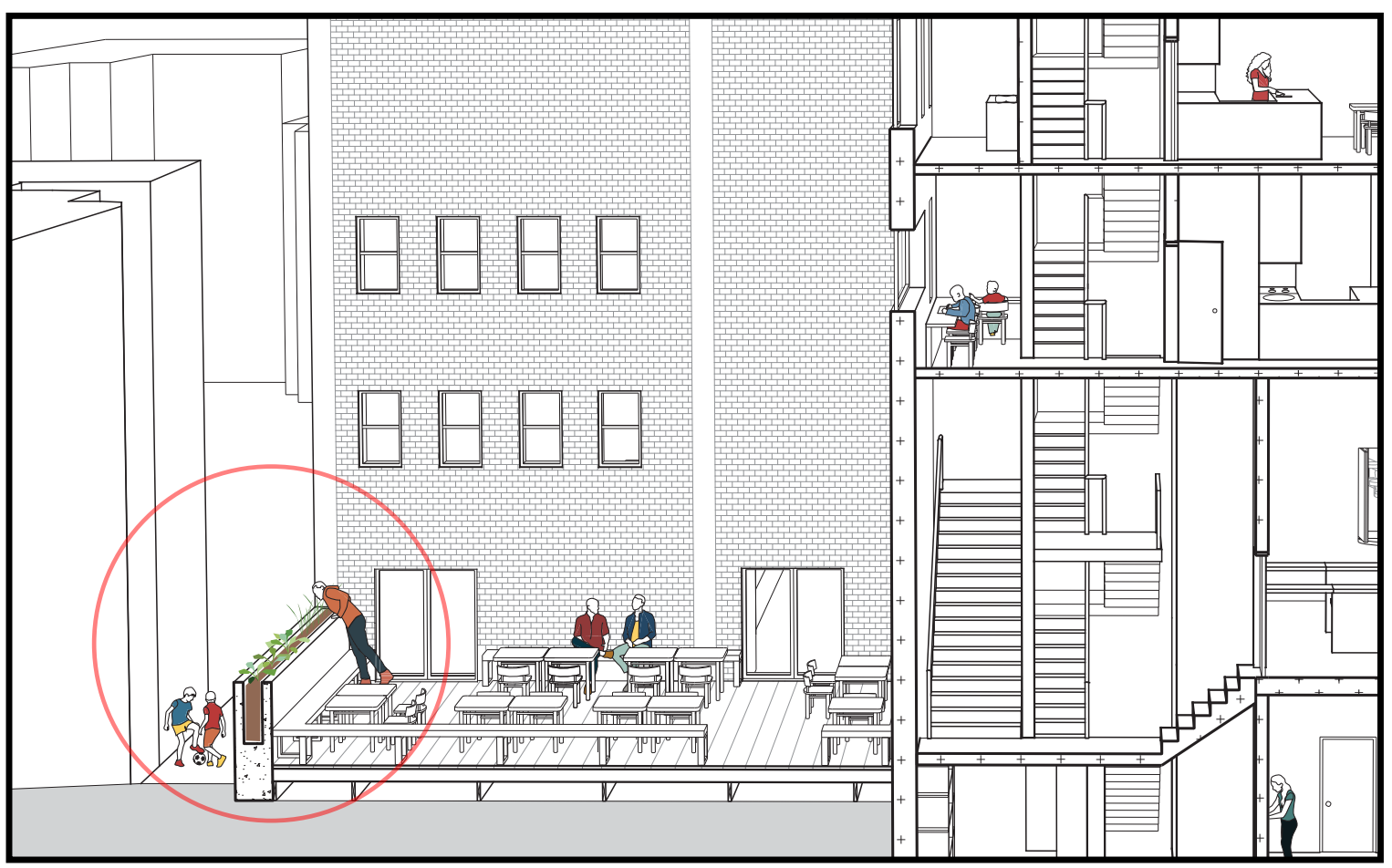

Fig. 5.3 Greg 
Greg lives in the neighbourhood and works for a green roof company. He does the plants maintenance. He works early in the morning, and often comes for coffee in the bar in the afternoon. That's where he met Felix, the bartender. Felix likes to try new cocktail recipes with fresh products so Greg offered to take care of his fresh herbs that grow on the terrace of the bar.

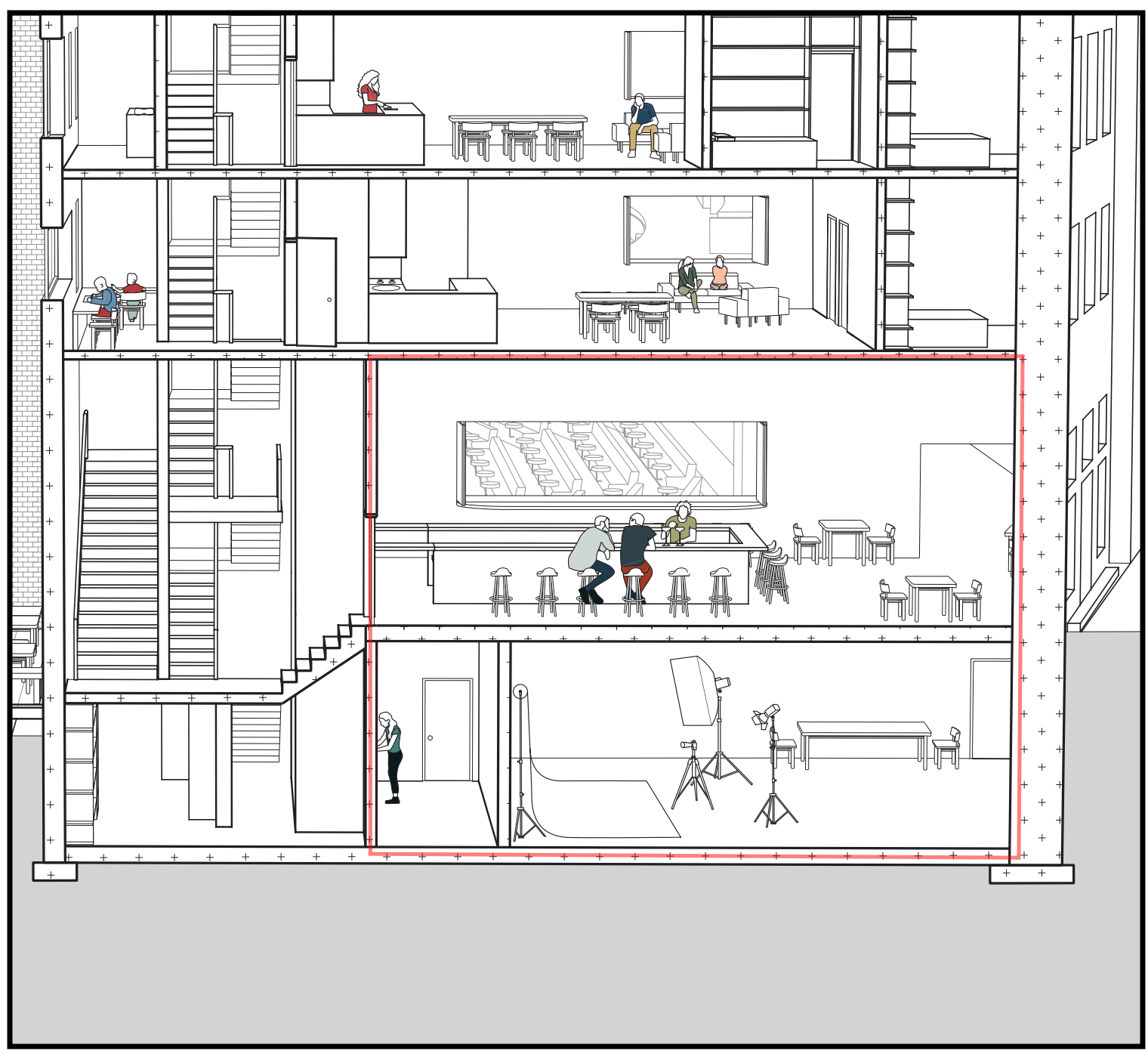

Fig. 5.4 Felix

As the local bartender, Felix meets all kinds of people from the neighbourhood. But he actually developed a true friendship with Etienne who comes for a drink every Thursday night. They discuss images and and films because Felix also does photography and often uses the studio just below the bar to develop his shots. 


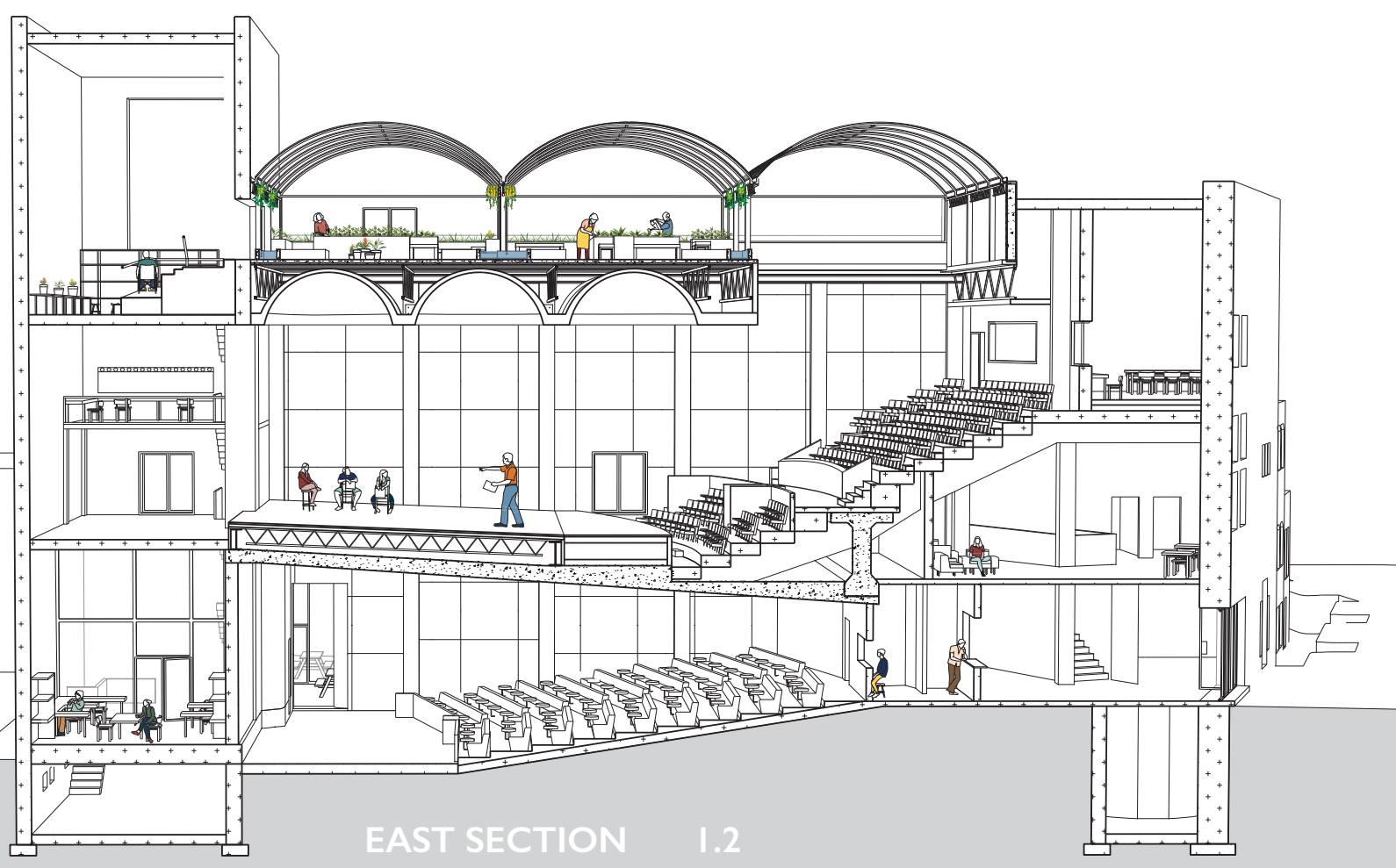

Fig. 5.5 East Section I.2

Etienne is a self-employed film maker and he rents out a desk in the studio behind the screening room. There he can work quietly while also enjoying the input and shared knowledge of other freelancers, renting out desks. They sometimes organize lectures about cinema in the screening room behind which they are located. At lunchtime, Etienne always goes up to the greenhouse to eat his sandwich. That's where he met Helen.

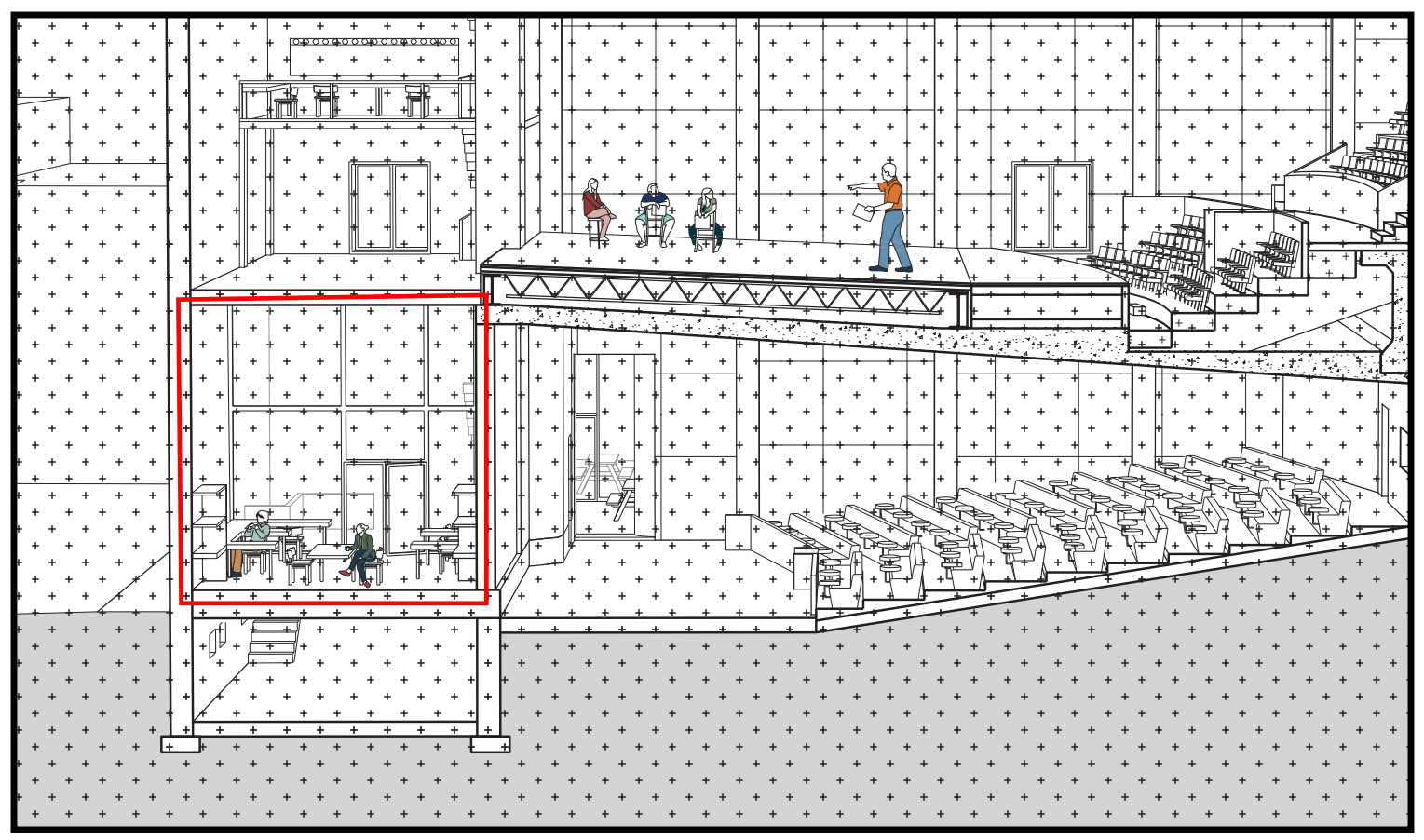

Fig. 5.6 Étienne 
Helen used to be a horticulturist and had her own landscaping company, but she is now retired. Having lots of free time, she decided to volunteer to take care of the greenhouse, and once a month she gives workshops on how to take care of your house plants.

Helen has bad knees from all the gardening so she always takes the elevator to get to the garden. That's where she met Dominic.

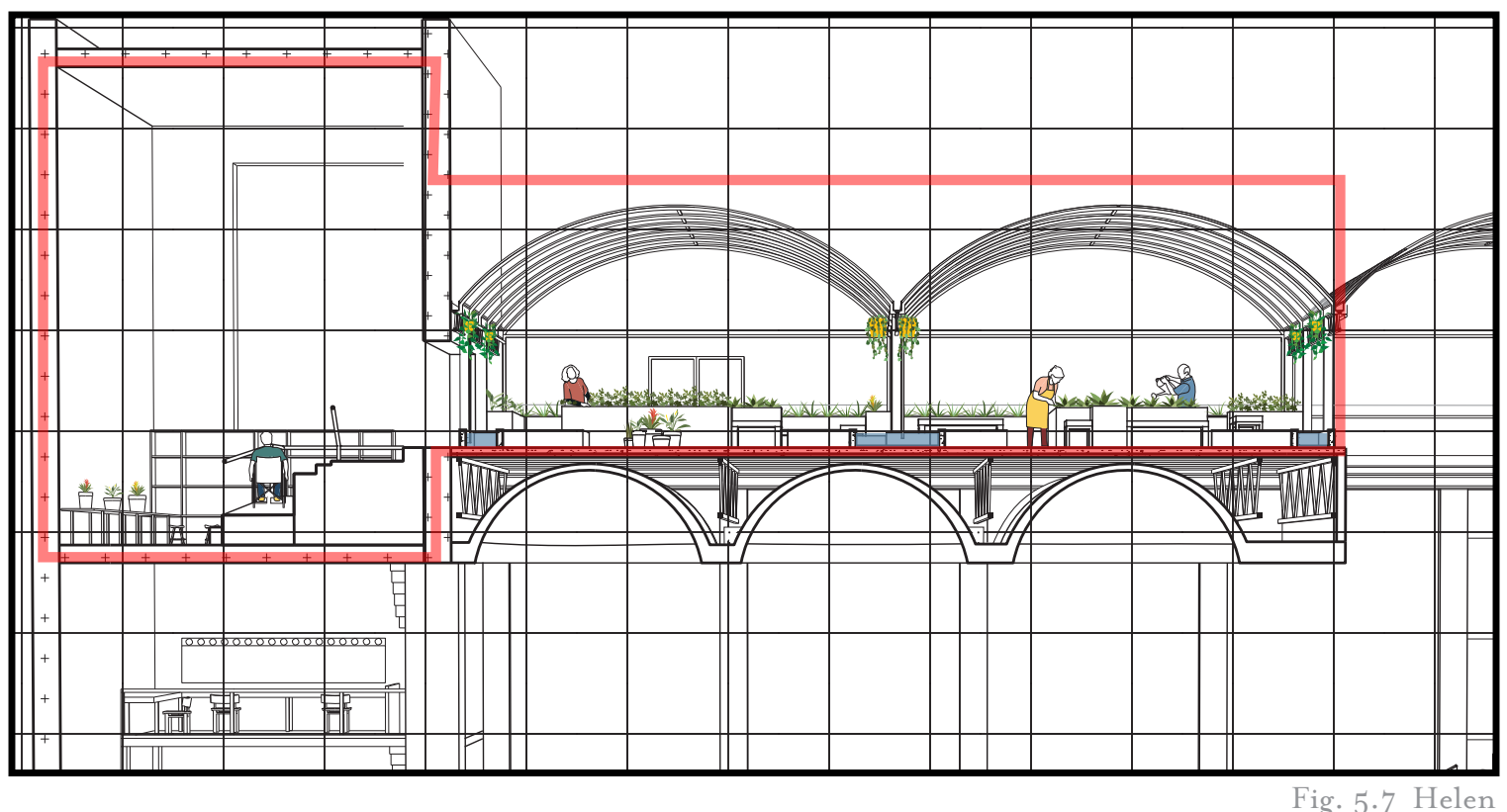

Dominic used to take the front stairs to get to the theatre but when he sprained his ankle he started using the elevator in the back. Dominic is a substitute literature teacher who's trying to make his way into the system. In the meantime, he organizes a theatre group that meets once a week to practice in the theatre hall. He plans the rehearsals schedule with Tony, who works at the front desk.

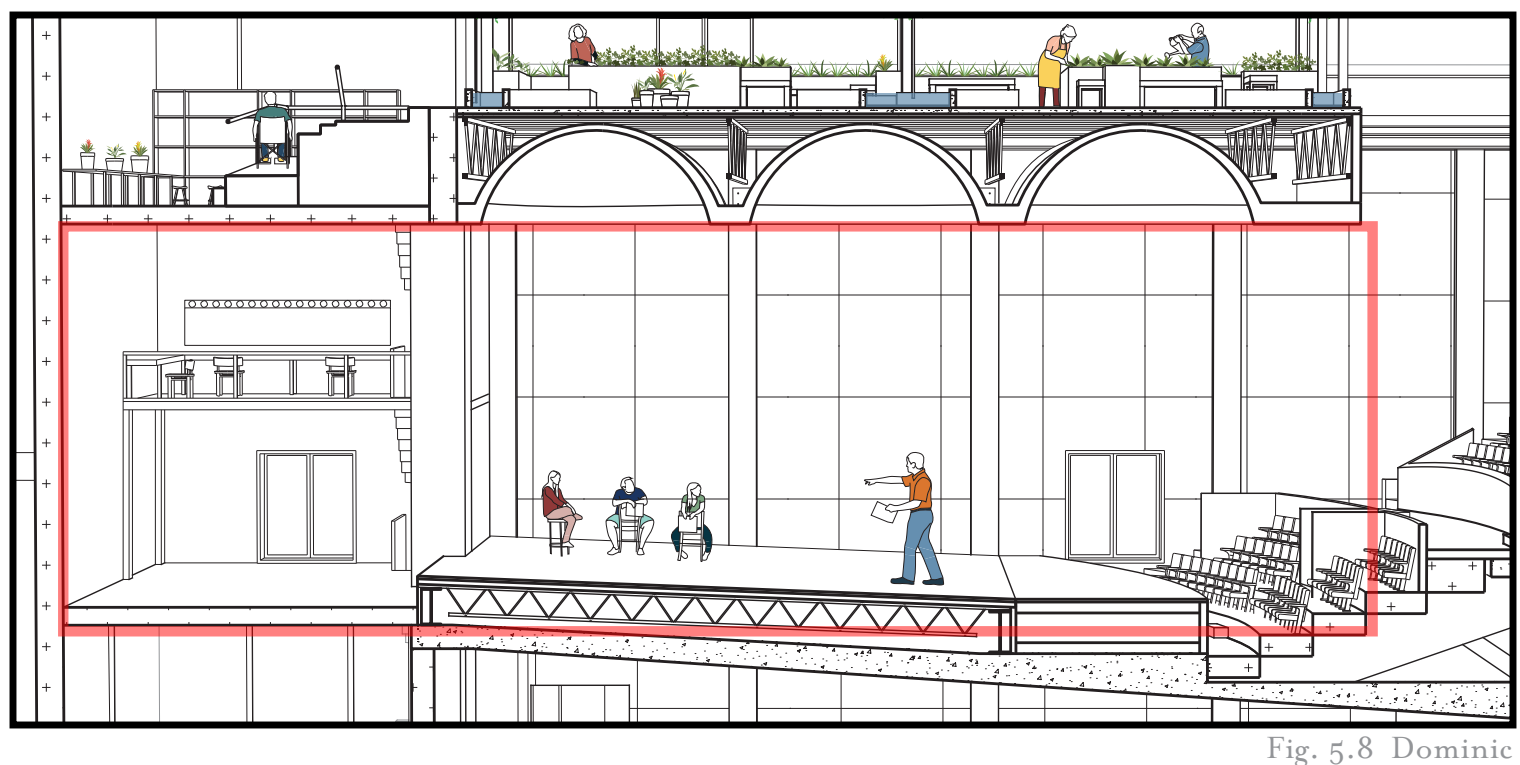




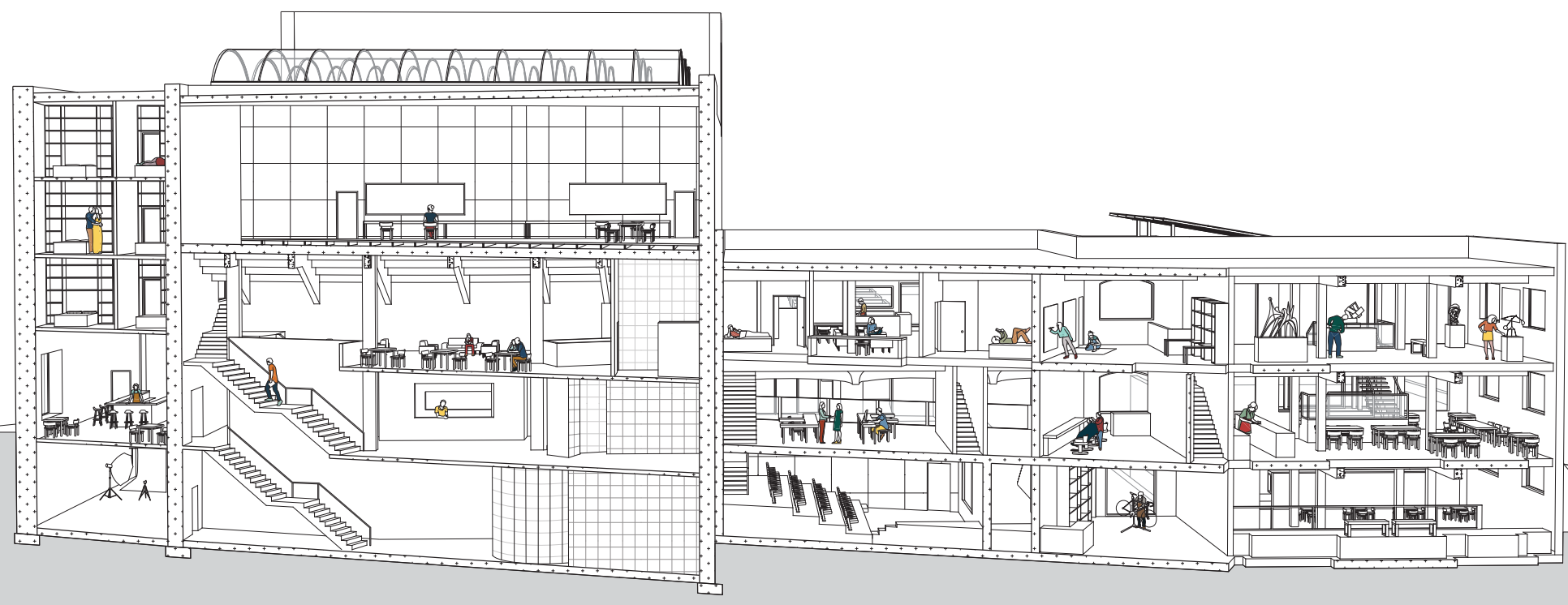

NORTH SECTION 2.I

Fig. 5.9 North Section 2.I

Tony is a huge fan of cinema and works in the field on a contractual basis. The rest of the time he organizes the schedule for the theatre hall, the main screening room and also decides on the programming for the repertoire screening room. As Tony works the front desk, he also meets lots of people from the neighbourhood. That's how he met Paul, who was coming very often to watch French movies.

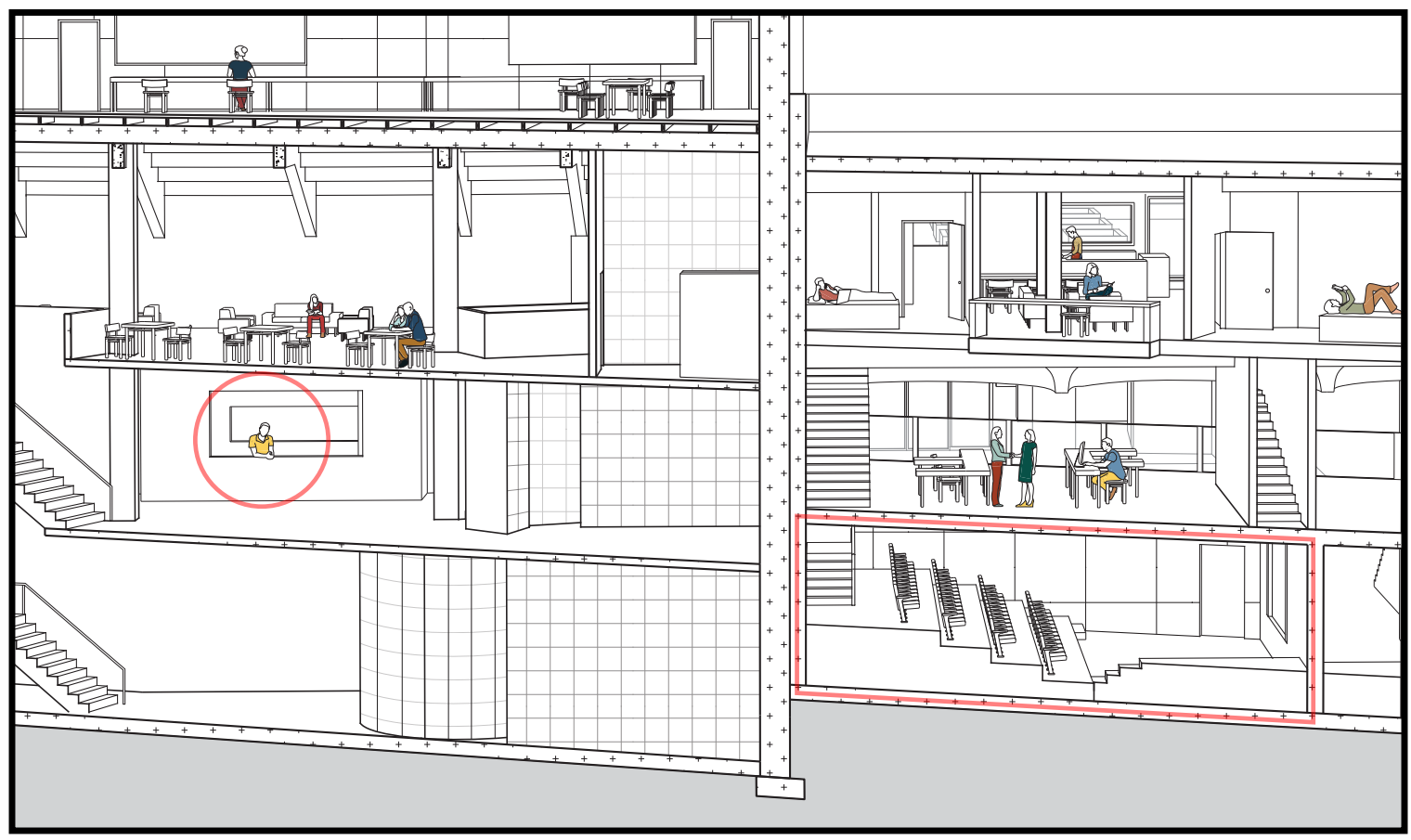

Fig. 5.IO Tony 


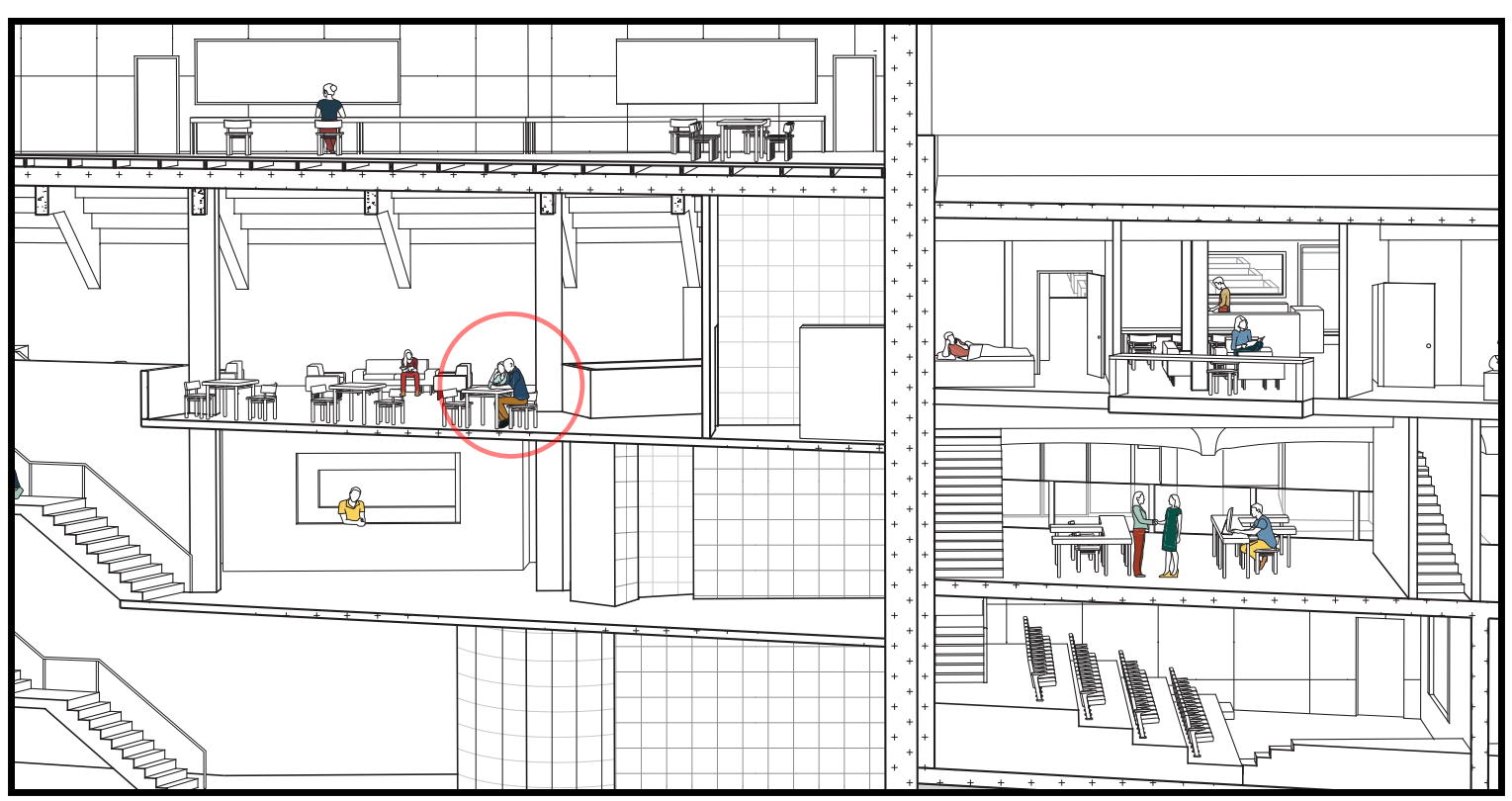

Fig. 5.II Paul

Paul is actually from Florida but recently married Saskia, (who you will meet a little later). They moved into the neighbourhood together a few months ago. Paul is trying to learn French, (therefore the French films), and so Tony asked his girlfriend Leilla, who's actually a lighting technician for the theatre, to ask one of her friends if she could help out Paul with some French classes. So twice a week, Paul and Sophie meet in the theatre's foyer, which is actually a co-working space during the day, to practice French.

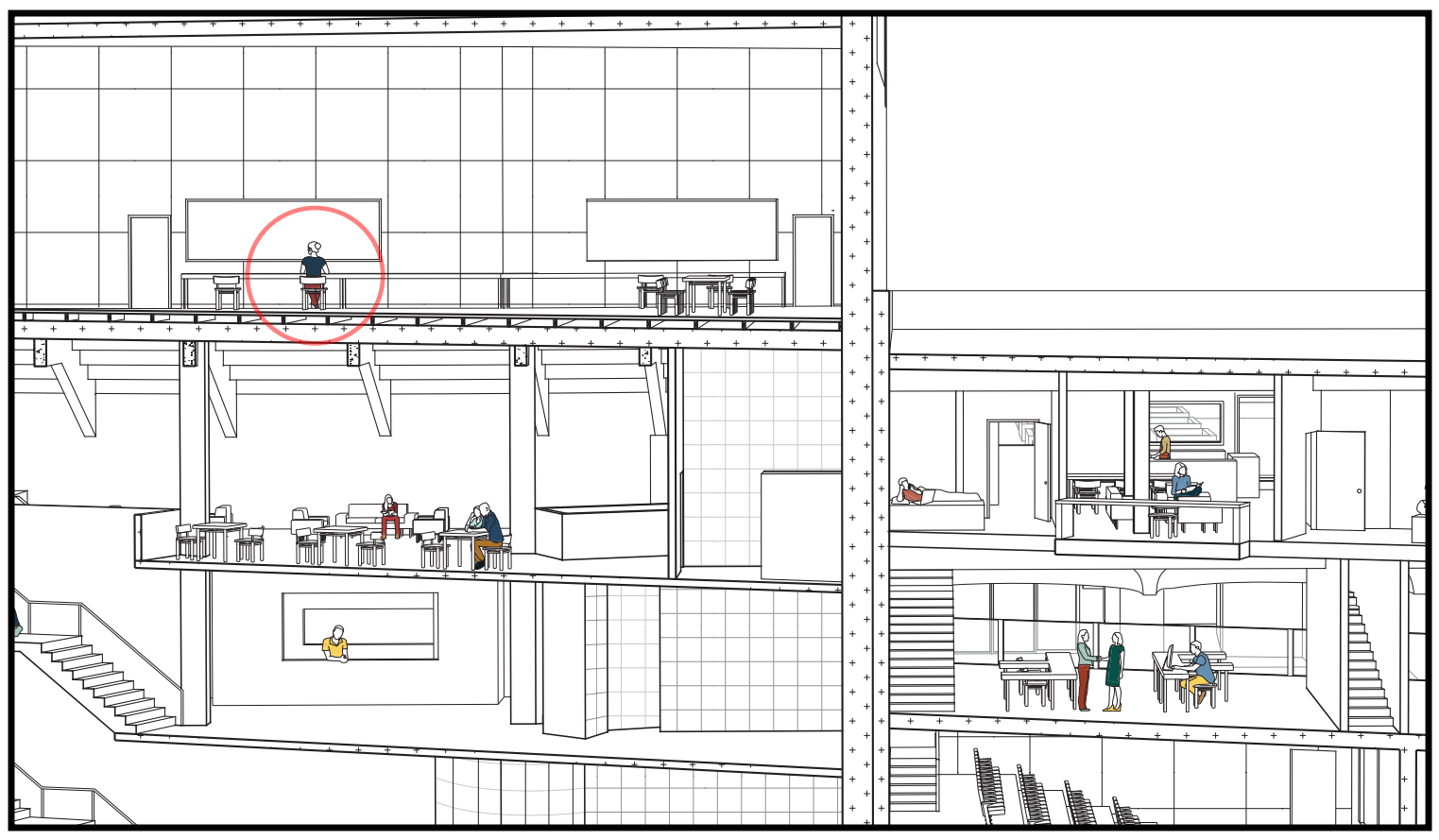

Fig. 5.I2 Leila 


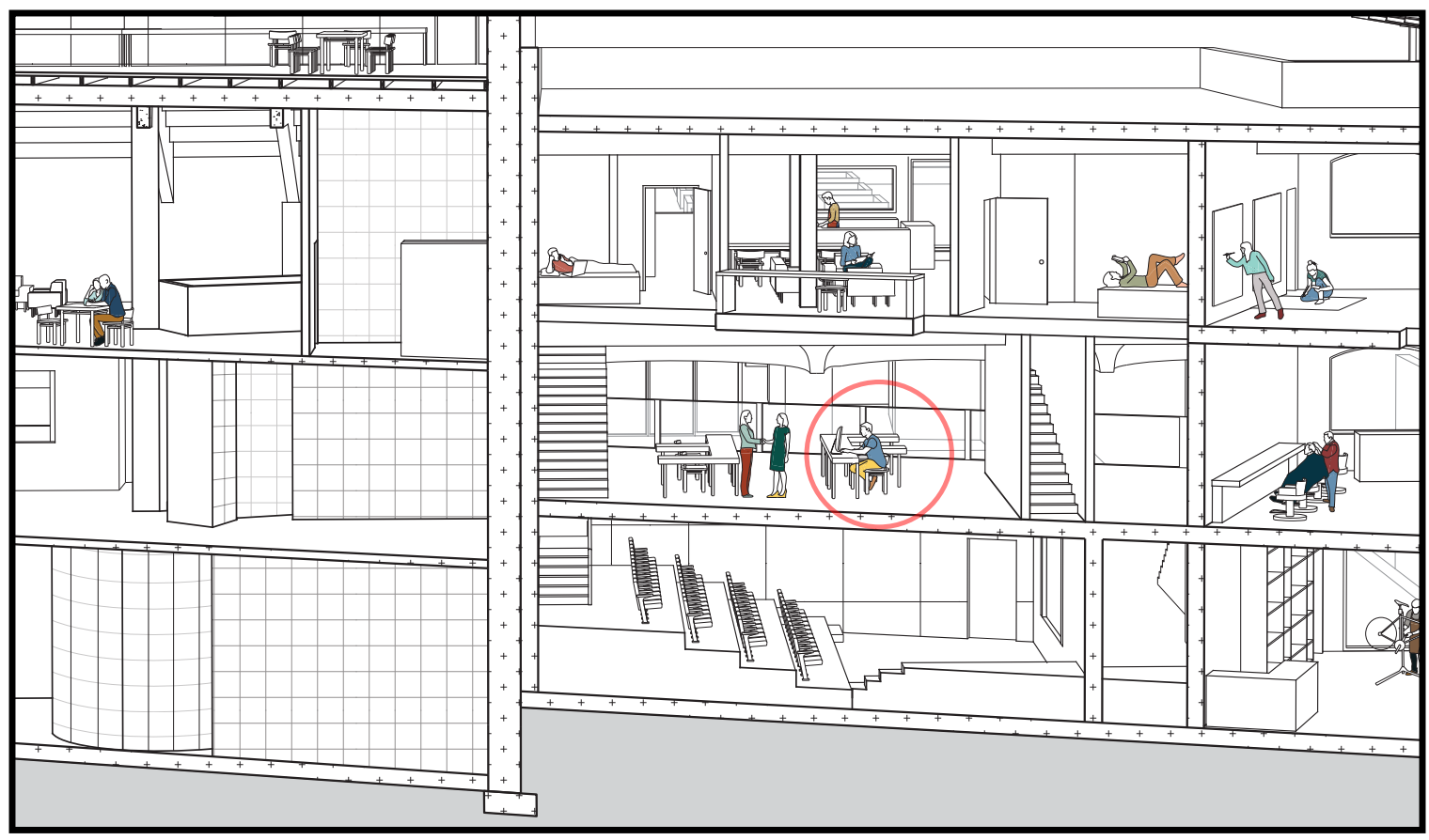

Fig. 5.13 Gabriel

Sophie also lives in the neighbourhood and her roommate Gabriel actually works for the market, next door. Gabriel does the administrative work in the mezzanine space. Gabriel studied urban planning but decided to not work in the field, although that's where he met Amahd.

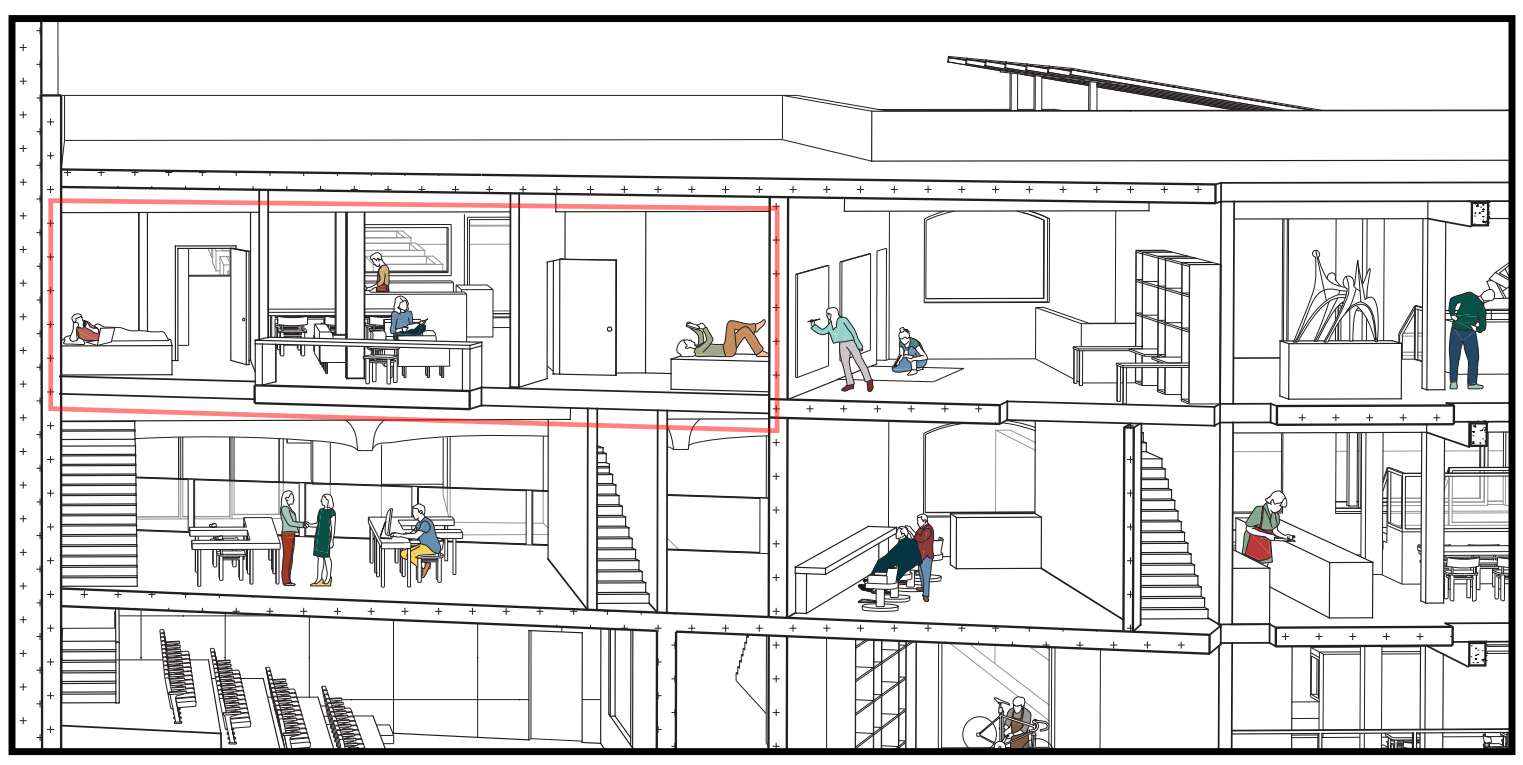

Fig. 5.I4 Amahd

Amahd is an Iranian refugee who came here to study, also urban planning, but he's also not working in the field. He is now a contemporary artist. He rents out one of the bedrooms in the shared apartment just above the administrative space. This way he can save up on rent and develop new relationships. This apartment also gives him direct access to the artist studio next door and this way he can also meet the artists in residence. 


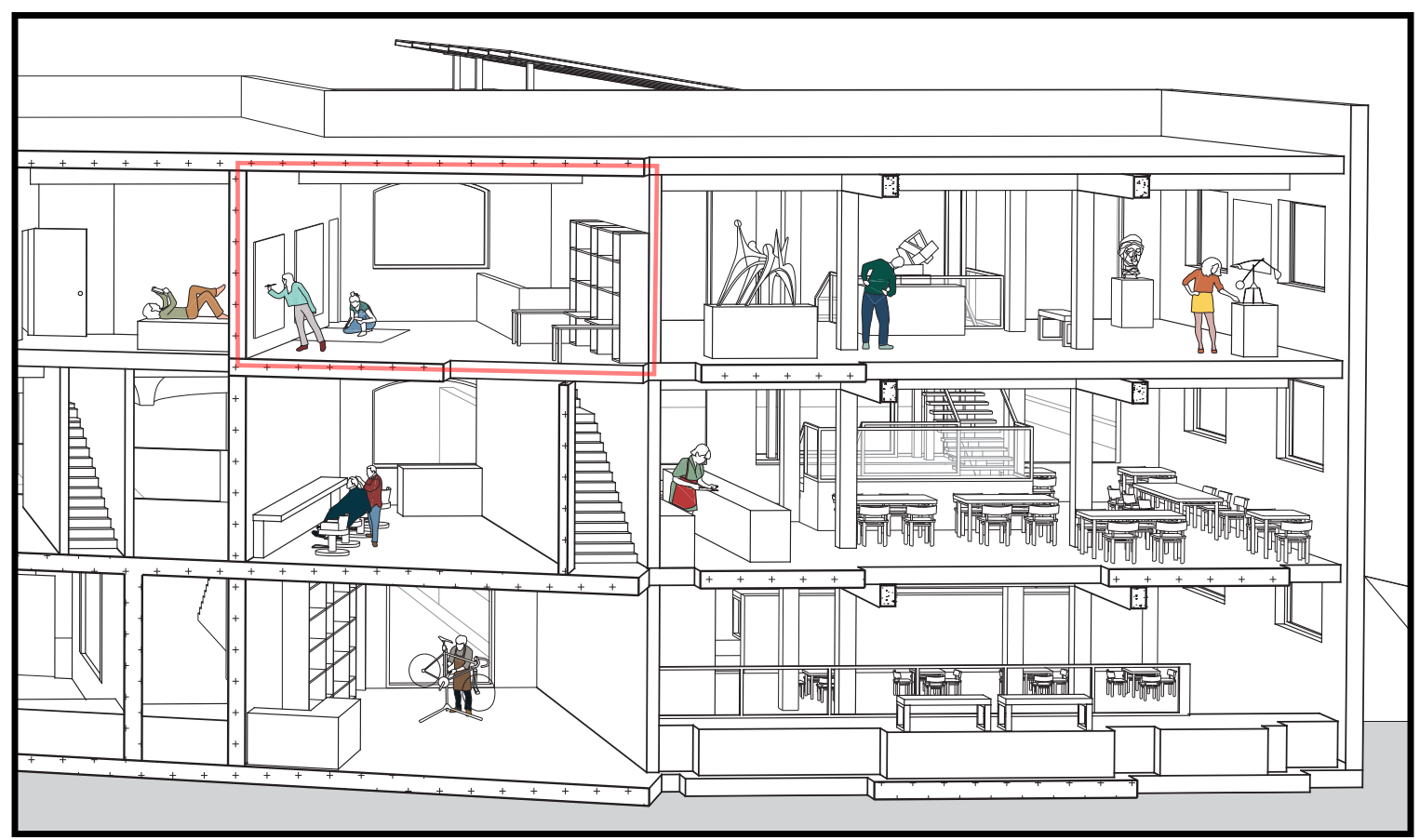

Fig. 5.I5 Jeanette

At the moment Jeanette from Winnipeg is using the studio, which is above the barber shop, which is above the bikeshop. Jeannette is actually Etienne's girlfriend and their daughter Irene goes to the daycare, below the gallery, on ground floor.

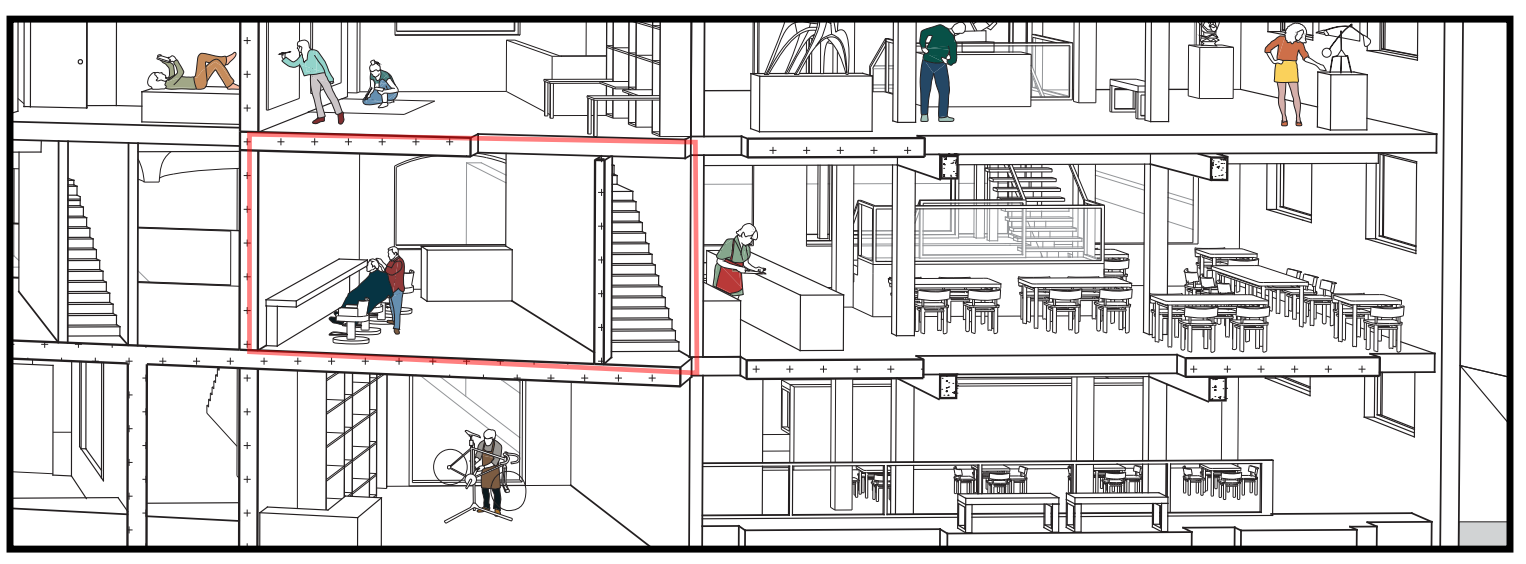

Fig. 5.I6 Barber Shop

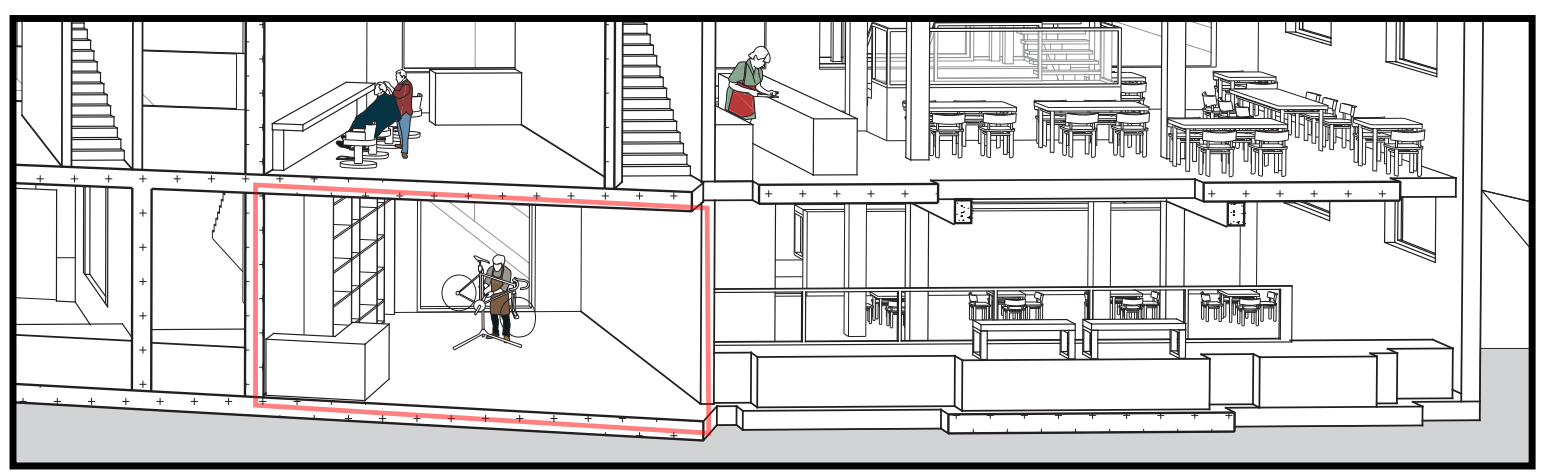

Fig. 5.I7 Bike Shop 


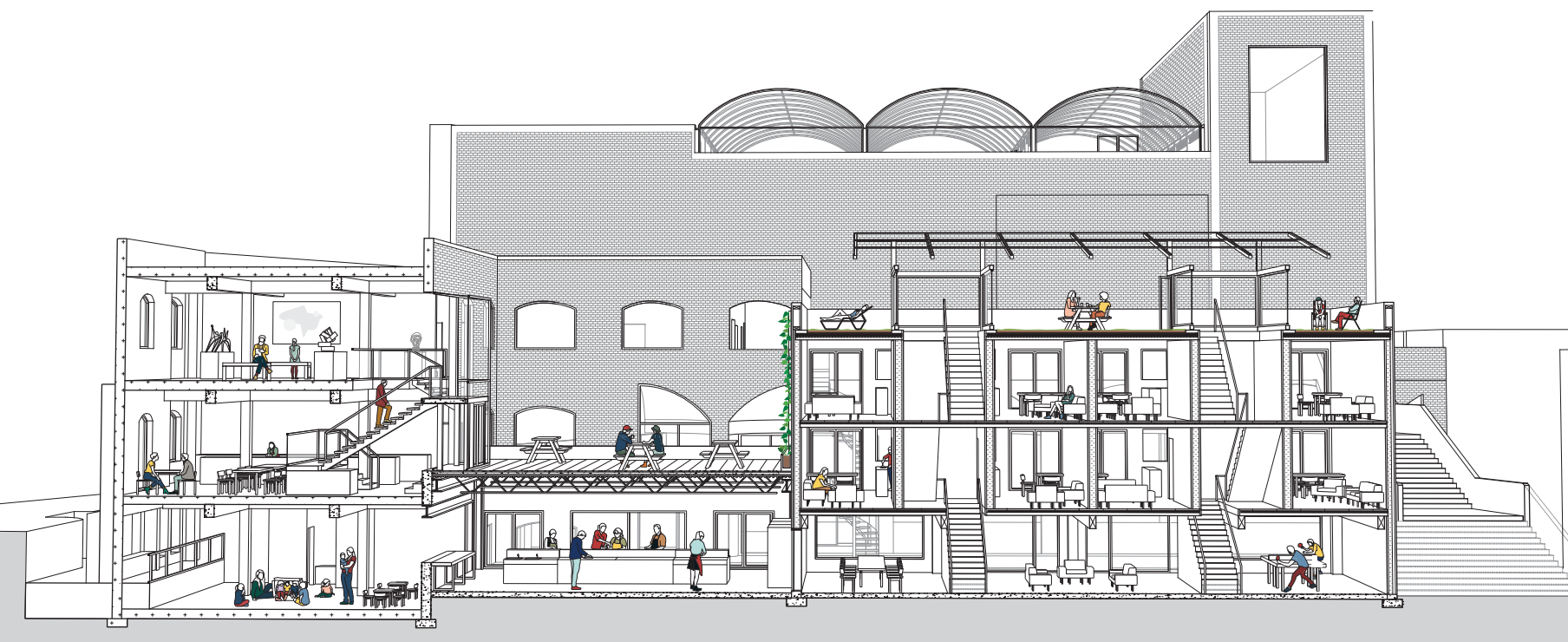

WEST SECTION $3 . \mathrm{I}$

Fig. 5.I8 West Section 3.I

Three days a week, when Etienne is working on his film, Irene goes to the daycare, where Saskia, (Paul's wife), takes care of her and the other kids. For their wedding, Saskia hired a local caterer that was so great that she asked her if she would be willing to give the kids some cooking classes once in awhile. Which Sylvia agreed to. Now she also gives cooking classes to all age groups.

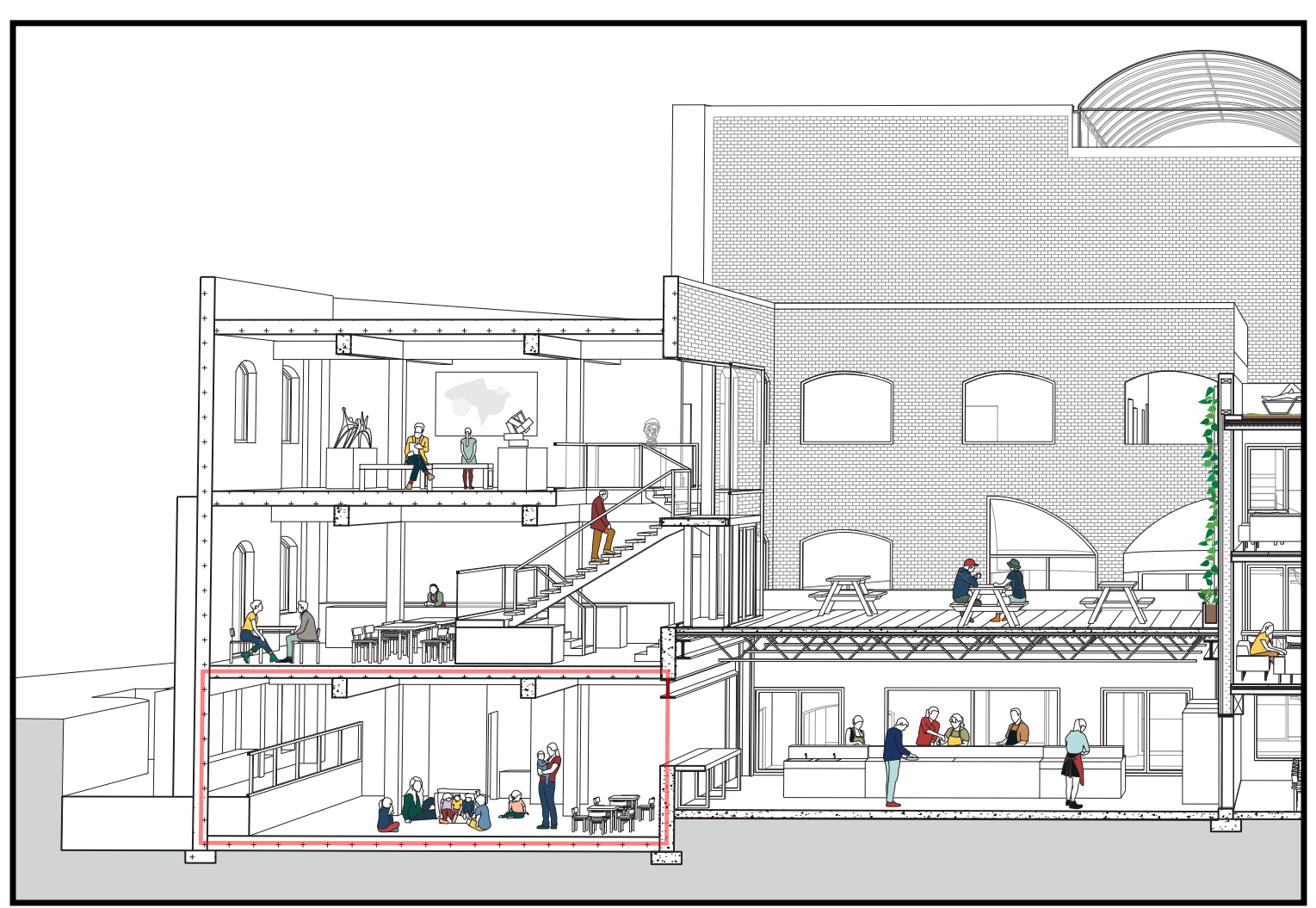

Fig. 5.I9 Irene 


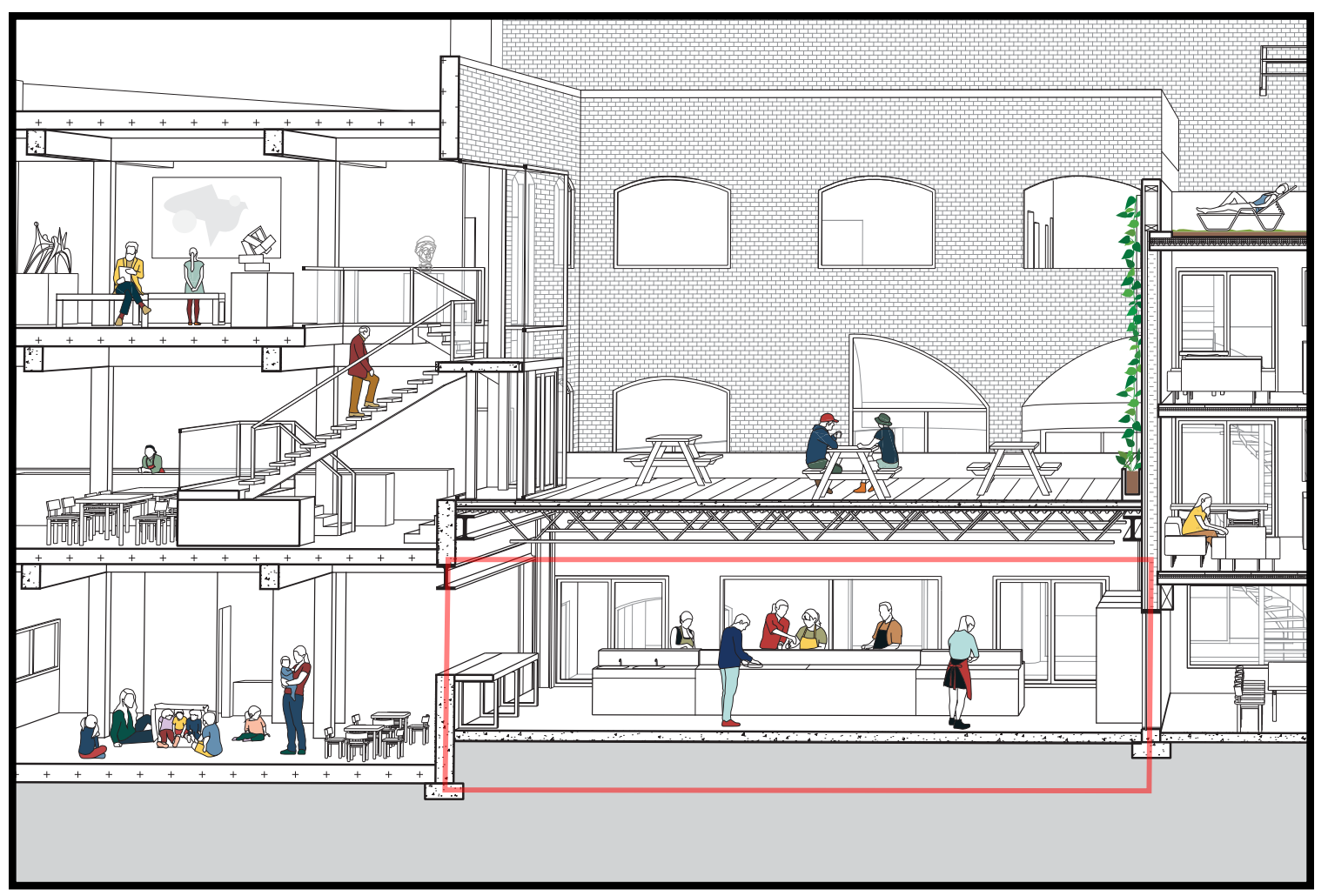

Fig. 5.20 Sylvia

When Sylvia gives afternoon classes, her husband Axel who's an art history teacher, usually waits for her at the gallery upstairs. He always has a chat with Mai, the head chef of the restaurant who's also very found of art. Mai actually introduced Axel to her nephew Liem when Axel had trouble with his laptop.

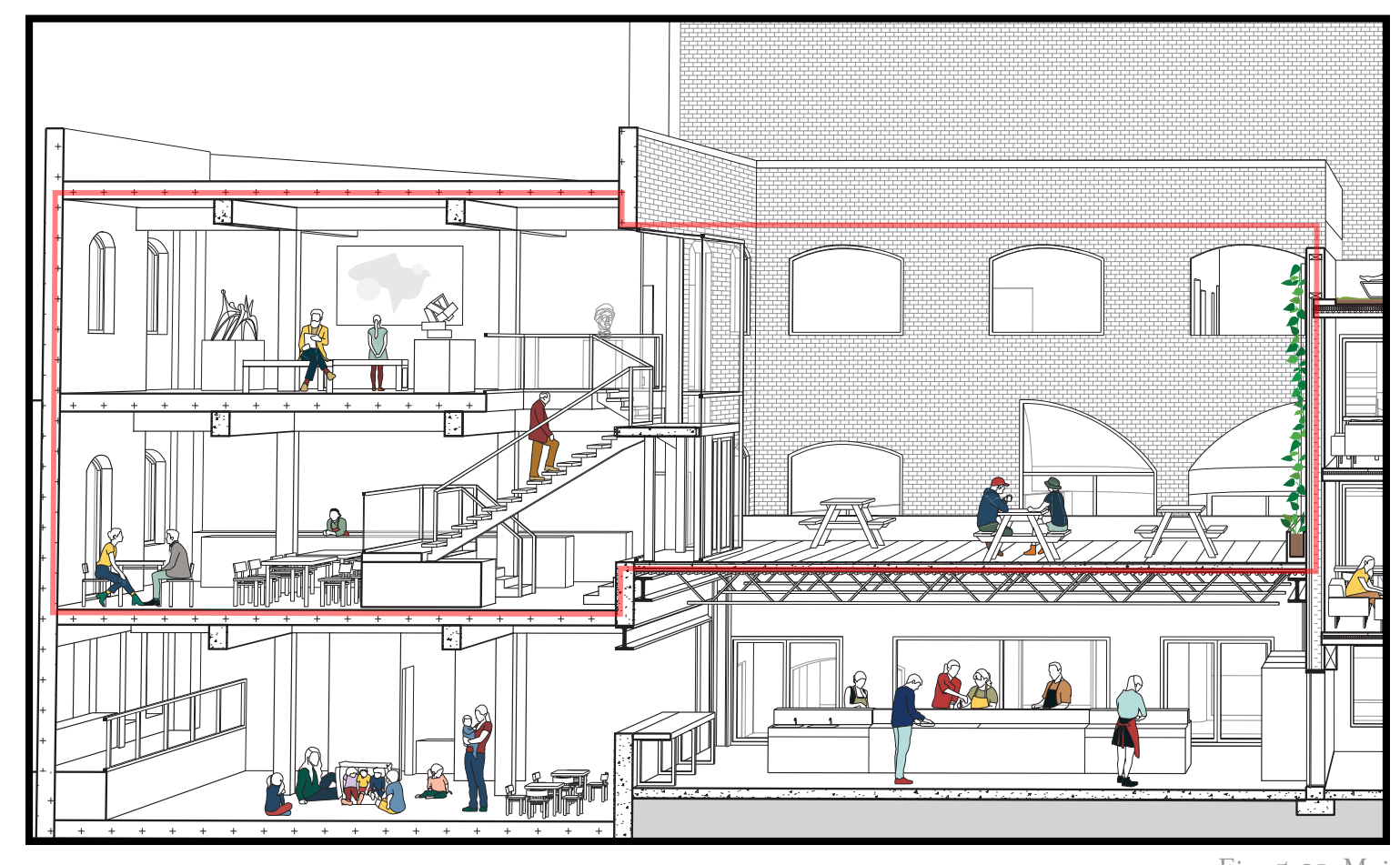




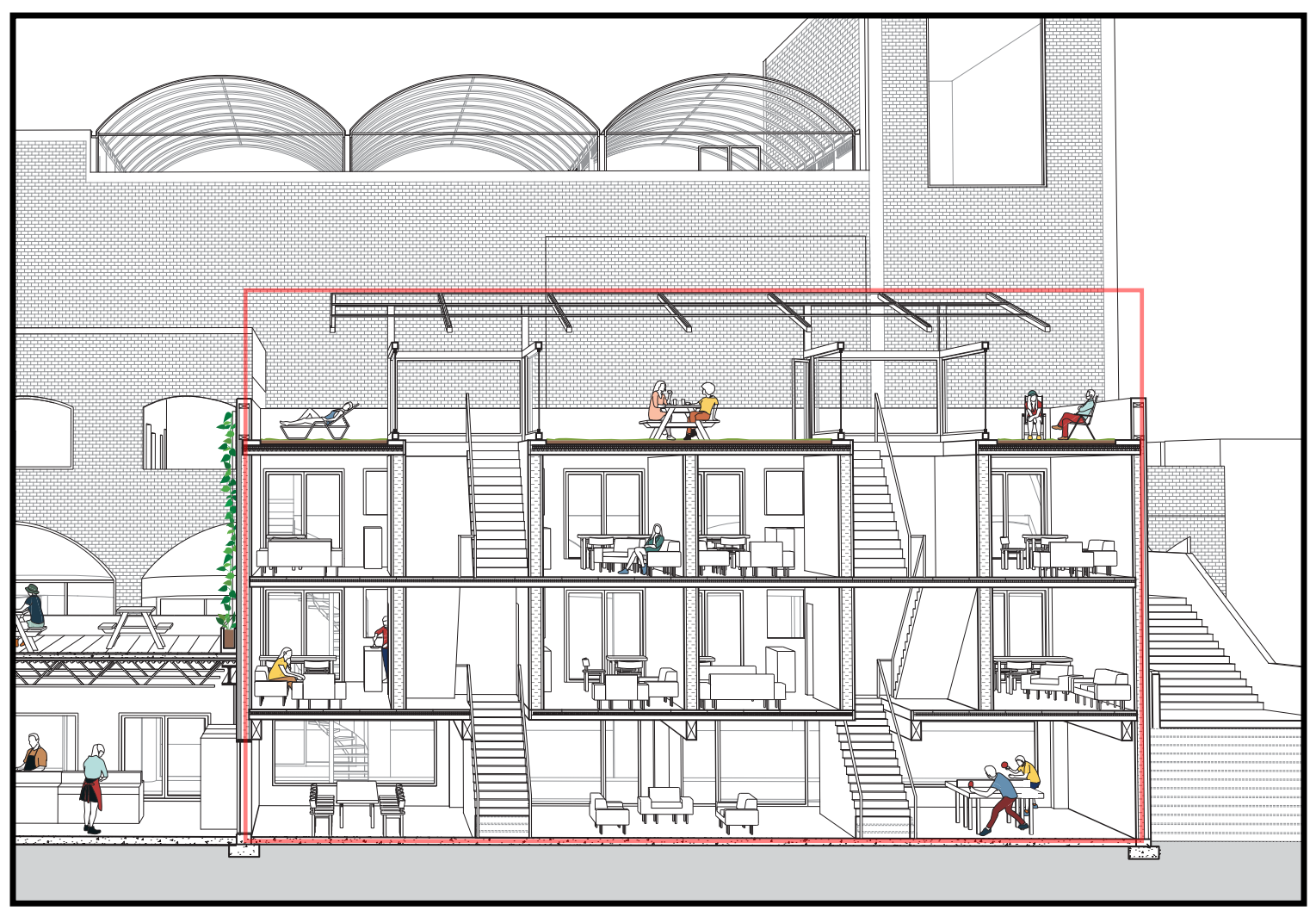

Fig. 5.22 Liem

Liem is a computer engineer who recently emigrated from Vietnam. Mai found him a studio apartment in the new building, right behind the restaurant. Since Liem lives alone, he often hangs out in the communal space on the ground floor. That's where he met Heythem, a great ping pong player with whom he started playing regularly and developed a friendship. Heythem also lives in one of the studios with his wife, Catherine.

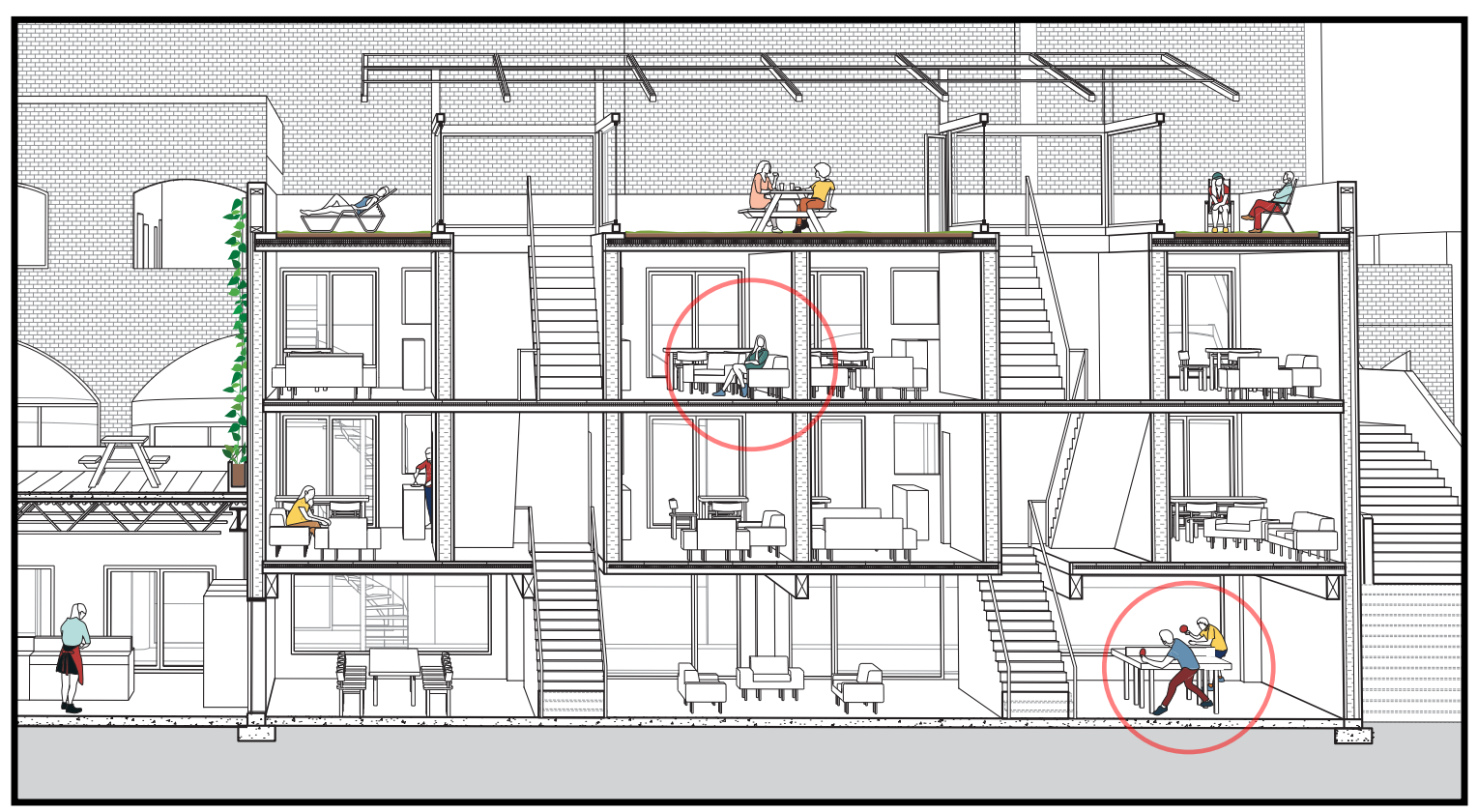

Fig. 5.23 Catherine 


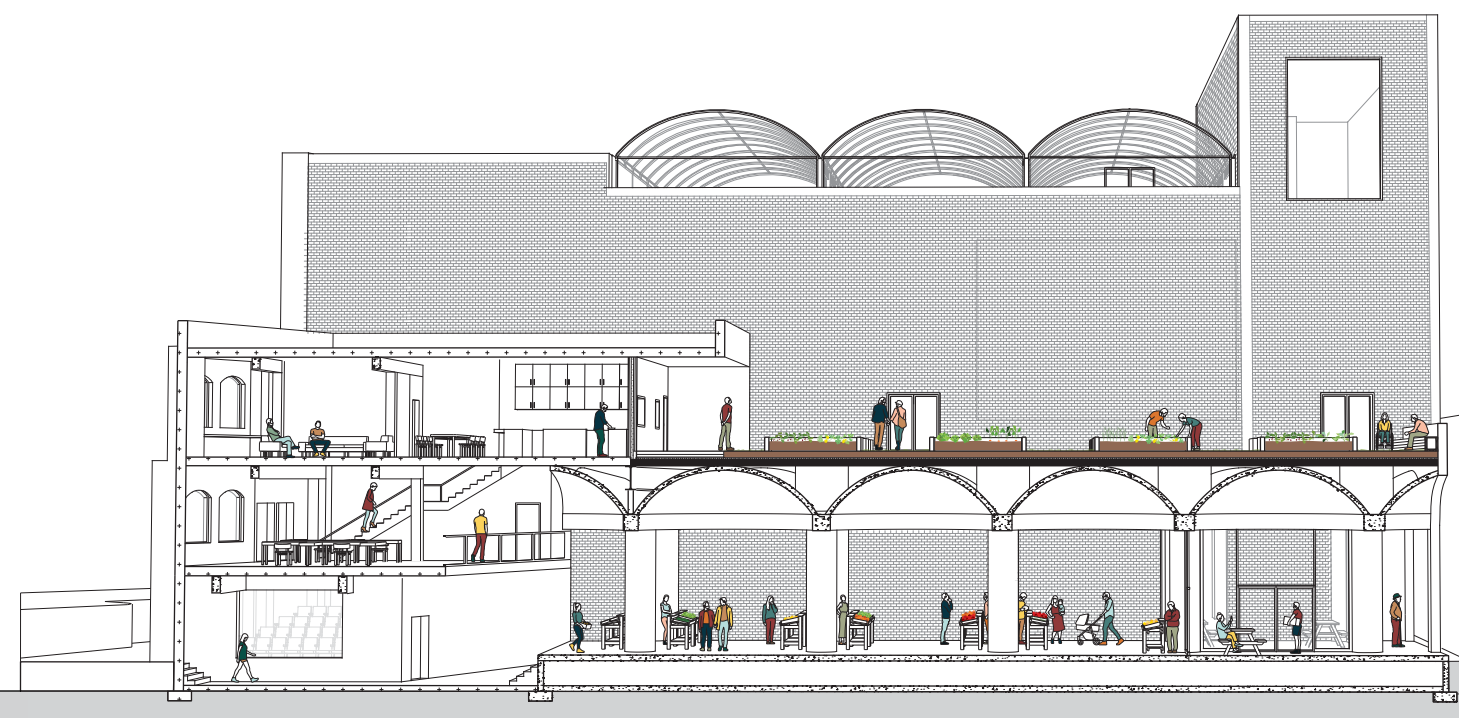

WEST SECTION 3.2

Fig. 5.24 West Section 3.2

Catherine has a plot in the community garden behind her building. Since it's her first time growing her own vegetables, she asked for tips from her plot neighbour, Suzan.

Suzan's vegetables are in such great shape that she sells some at the market below once in awhile. Selling her tomatoes, she met Marie.

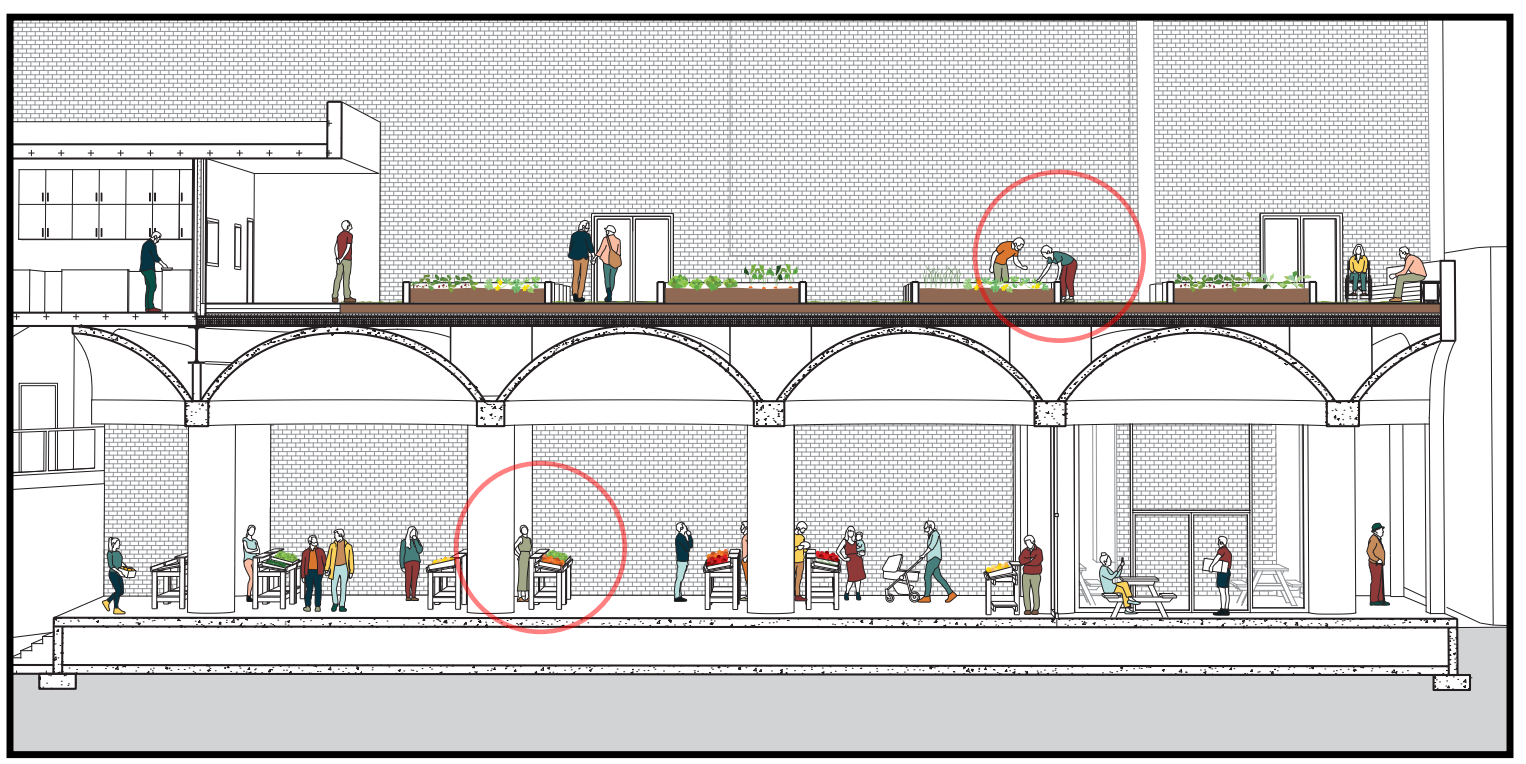

Fig. 5.25 Marie

Marie buys all of her vegetable at the market to encourage the local economy. She's a lawyer and gives tips to Gabriel with the legal stuff for the market when she can. Marie also lives in the annex. She's Abdou's mother. 


\section{Looking Forward}

Since 1992, the Empress Theatre has been sitting empty. At the end of April 2020, a public consultation will take place regarding the fate of the Empress Theatre. As far as we know now, the borough of N.D.G. and Cote-des-Neiges will allegedly donate up to $250000 \$$ to the Société d'habitation et de développement de Montréal, the city's public housing agency. They proposed "to transform the former Cinema $\vee$ into a mixed-use facility that will include artistic and community spaces and affordable housing units for artists as well as retail space." I intend to attend these public consultations. ${ }^{\text {I }}$

I Frédéric Tomesco, "Decrepit Empress Theatre set to be redeveloped into mixed-use facility", Montreal Gazette 


\section{Bibliography}

\section{Printed}

Bédard, Camille."Traveling in Time and Space:The Cinematic Landscape of the Empress Theatre," in Oriental Interiors: Design, Identity, Space. University of Pennsylvania Press, Volume 42, Number 2, 2017.

Çalıskan, Olgu, Duygu Cihanger Ribeiro and Onur Tümtürk. "Designing the heterotopia: from social ideology to spatial morphology”. METU Faculty of Architecture,Ankara, Turkey, 2019.

DeCerteau, Michel, Giard Luce and Mayol Pierre. "The Market." in The Practice of Everyday life. University of Minnesota Press. vol. 2, 1998, p. 107-I I3, trans. by Timothy J.Tomasik.

Foucarde, Marie-Blanche. Montreal's Cultural Diversity Heritage. Encyclopédie du patrimoine culturel de l'Amérique française, 2009. http://www.ameriquefrancaise.org/fr/

Foucault, Michel. "Of Other Spaces: Utopias and Heterotopias," in Architecture, Mouvement, Continuité. no. 5, October 1984, p. 46-49; trans. Jay Miskowiec in Diacritics 16, (no.I, 1986) p.22-27.

Klinenberg, Eric. Palaces for the People. New York: Crown, 2018.

Laberge, Jean. Énoncé de l'intérêt patrimonial du théâtre Empress. Montreal, Patrimoine Montréal, 2014. https://ville.montreal.qc.ca/pls/portal/docs/PAGE/PATRIMOINE_URBAIN_FR/MEDIA/ DOCUMENT/\%C9NONC\%C9_TH\%C9\%C2TRE_EMPRESS_FINAL.PDF

Lanken, Dane. "Montreal Movie Palaces.” The Society for the Study of Architecture in Canada. vol. I4, 1989, p. $40-44$

Mostafavi, Mohsen and Gareth Doherty. "Why Ecological Urbanism? Why Now?" in Ecological Urbanism. Harvard University Graduate School of Design with Lars Müller Publishers, Cambridge, 2010.

Paquin Christian. “Portrait Statistique C.D.N./N.D.G. 2016.”Ville de Montréal, 2018. http://ville.montreal.qc.ca/pls/portal/docs/PAGE/ARROND_CDN_FR/MEDIA/DOCUMENTS/PORTRAIT\%20CDNNDG-2016.PDF

Pelletier, Louis. "The Fellows Who Dress the Pictures: Montreal Film Exhibitors in the Days of Vertical Integration (1912-1952)." PhD thesis, Concordia University, Montreal, 2012. 
Schwartz, Catriona. "Urban Archaeology: Montreal's Empress Theatre and Discovering its Connection with the Temple of Horus at Edfu." Concordia Undergraduate Journal of Art History,

Wilkinson, Alix. "Symbolism and Design in Ancient Egyptian Gardens" in Garden History. vol.22, no. I, 1994, p. I-I7

Plan du quartier vert actif et en santé NDG sud-est. Centre d'écologie urbaine de Montréal, 20I I. http://ocpm.qc.ca/sites/ocpm.qc.ca/files/pdf/P65/4a.pdf

“The New Empress Theatre, Montreal”, The Journal Royal Architectural Institute of Canada. vol.V, no. I I, November 1928, p.392-396 


\section{Web}

"Biennale Architettura 2020: How will we live together?," La Biennale DiVenezia. Updated 27 February 2020. https://www.labiennale.org/en/news/biennale-architettura-2020-how-will-we-live-together

Bâtiment 7.“Our mission.” About. 2018. https:/www.batiment7.org/en/about/

Butler, M. Stuart and Carmen Diaz.“ “Third Places as Community Builders' ”, Brookings,. September 14, 2016, https://www.brookings.edu/blog/up-front/2016/09//4/third-places-as-community-builders/

Cameron, Daphné. "Côte-des-Neiges - Notre-Dame-de-Grâce: deux quartiers, deux réalités." La Presse, October 13, 2013.

https://www.lapresse.ca/actualites/elections-municipales-2013/201310/3 I/0I-

4705750-cote-des-neiges-notre-dame-de-grace-deux-quartiers-deux-realites.php

Cottrell Boyce, Frank. “Cultivating Grow Your Own” in The Guardian, May 10, 2007. https://www.theguardian.com/film/filmblog/2007/may/I0/cultivatinggrowyourown

Crook, Lizzie. "Assemble transforms two derelict terrace houses into Granby Winter Garden”. Dozen (26 April 2019). https://www.dezeen.com/2019/04/26/assemblegranby-winter-garden-architecture-liverpool/

Gates, Theaster. "Chicago Arts and Industry Commons", Projects,. 2019. https://www.theastergates.com/project-items/chicago-arts-and-industry-commons/images?view=thumbnails

Heritage Montreal. “Théâtre Empress / Cinéma V.” August 2016.

https://www.heritagemontreal.org/plateforme-h-mt//?siteSlug=theatre-empresscinema-va/rpcq/detail.do?methode=consulter\&id=7364\&type=pge\#.XfKG6pNKiRt

Hitti, Natasha."Plantea transforms defunct erotic cinema into contemporary art-nouveau theatre". Dezeen (29 November 2018)

https://www.dezeen.com/2018/I I/29/plantea-cinema-art-nouveau-madrid/

Tomesco, Frédéric. “Decrepit Empress Theatre set to be redeveloped into mixed-use facility" Montreal Gazette, March 7, 2020. https://montrealgazette.com/business/local-business/real-estate/ decrepit-empress-theatre-set-to-be-redeveloped-into-mixed-use-facility/ 


\section{Images \& Maps}

Fig. I.0

"Palaces for the People." Amazon, 2018.

https://www.amazon.com/Palaces-People-Infrastructure-Inequality-Polarization/ $\mathrm{dp} / 1524761 / 68$

Fig. 2.2

“N.D.G. Census 2016",Ville de Montréal, 2018.

http://ville.montreal.qc.ca/pls/portal/docs/PAGE/ARROND_CDN_FR/MEDIA/DOCUMENTS/PORTRAIT\%20CDNNDG-2016.PDF

Fig. 2.5

"Empress Theatre." The Journal Royal Architectural Institute of Canada. vol.V, no.I I, November 1928, p.392

Fig. 2.6

"Empress Theatre - Section." The Journal Royal Architectural Institute of Canada. vol.V, no.I I, November 1928, p.393

Fig. 2.7

"Empress Theatre - West Wall." The Journal Royal Architectural Institute of Canada. vol.V, no.I I, November 1928, p.394

Fig. 2.8

"Empress Theatre - Arch \& Curtain." The Journal Royal Architectural Institute of Canada. vol.V, no.I I, November 1928, p.395

Fig. 2.9

"Empress Theatre - Mezzanine Floor." The Journal Royal Architectural Institute of Canada. vol.V, no. I I, November 1928, p.395

Fig. 2.10

“Empress Theatre - 1928." Atelier Nuno Architects. https://www.ateliernuno.hk/digitalgallery

Fig. 2.II

“Empress Theatre - 1943.” Empress Theatre.Wikipedia. https://en.wikipedia.org/wiki/Empress_Theatre_(Montreal) 
Fig. 2.12

"Cinema V - 1989." CBC Montreal

https://www.cbc.ca/daybreakmontreal/our-show/20I I/08/I6/whither-the-empress-theatre/

Fig. 2.14

"Cinema NDG - 2014" Given by the NGO Cinema NDG

Fig. 2.15

"Cinema NDG - 2014" Given by the NGO Cinema NDG

Fig. 2.16

"Cinema NDG - 2014" Given by the NGO Cinema NDG 